\title{
Selenide Mineralization in the Příbram Uranium and Base-Metal District (Czech Republic)
}

\author{
Pavel Škácha ${ }^{1,2, *}$, Jiři Sejkora ${ }^{2}$ and Jakub Plášil ${ }^{3}$ \\ 1 Mining Museum Příbram, Hynka Kličky Place 293, Příbram VI, 26101 Březové Hory, Czech Republic \\ 2 Department of Mineralogy and Petrology, National Museum, Cirkusová 1740, Prague 9, \\ 19300 Horní Počernice, Czech Republic; jiri_sejkora@nm.cz \\ 3 Institute of Physics ASCR, v.v.i., Na Slovance 2, 18221 Prague 8, Czech Republic; plasil@fzu.cz \\ * Correspondence: skacha-p@muzeum-pribram.cz; Tel.: +420-318-626-307
}

Academic Editor: Hans-Jürgen Förster

Received: 3 March 2017; Accepted: 29 May 2017; Published: 4 June 2017

\begin{abstract}
Selenium mineralization in the Příbram uranium and base-metal district (Central Bohemia, Czech Republic) bound to uraninite occurrences in calcite hydrothermal veins is extremely diverse. The selenides antimonselite, athabascaite, bellidoite, berzelianite, brodtkorbite, bukovite, bytízite, cadmoselite, chaméanite, clausthalite, crookesite, dzharkenite, eskebornite, eucairite, ferroselite, giraudite, hakite, klockmannite, naumannite, permingeatite, př́ibramite, sabatierite, tiemannite, and umangite were found here, including two new mineral phases: $\mathrm{Hg}-\mathrm{Cu}-\mathrm{Sb}$ and $\mathrm{Cu}-\mathrm{As}$ selenides. Those selenides-and in some cases their sulphidic equivalents-are characterized using wavelength-dispersive spectroscopy, reflected light, powder X-ray diffraction, single crystal X-ray diffraction, Raman spectroscopy, and electron backscatter diffraction. The selenide mineralization in the Přibram uranium district is bound to the border of the carbonate-uraninite and subsequent carbonate-sulphidic stages. Selenides crystallized there at temperatures near $100{ }^{\circ} \mathrm{C}$ in the neutral-to-weakly-alkaline environment from solutions with high oxygen fugacity and a high $\mathrm{Se}_{2} / \mathrm{S}_{2}$ fugacity ratio.
\end{abstract}

Keywords: selenides; chemical composition; crystal structure; wavelength-dispersive spectroscopy; X-ray diffraction; Příbram

\section{Introduction}

The Bohemian Massif belongs to those areas on a global scale having anomalously abundant occurrences of selenides. This is also true with respect to the number of determined selenide species. The first occurrence of selenides in the Bohemian Massif was recognized by Johan [1] at the Černý Di̊l uranium deposit in the Krkonoše Mountains. Later, large accumulations of selenides were found at the West-Moravian uranium deposits [2-4] and at the Předbořice uranium deposit in Central Bohemia [5-7]. Additional and important selenide occurrences were reported in Western Bohemia-Oldřichov near Tachov [8,9] and Ústaleč [10,11]. The Zálesí uranium deposit [12-15], the Jelení vrch [12], and the Bílá Voda [16] occurrences were discovered in the Rychlebské hory Mountains. The rich association of selenides from the uranium ore district Niederschlema-Alberoda in the Saxonian part of the Krušné hory Mountains was also studied in detail [17-23]. Recently, selenide occurrences tied to uranium-vanadium mineralization in the Prachovice quarry [24] and those associated with minor uranium mineralization at fluorite-baryte Moldava [25] and Běstvina [26] deposits were studied. 
Selenide occurrences outside uranium mineralization are only sporadic in the Bohemian Massif. Worthy of mention are rare finds of naumannite and tiemannite in the heavy mineral fraction of sediments near Svoboda nad Úpou [27]; Mo-selenides and clausthalite in black schists near Hromnice [28]; clausthalite and Ag-Cu selenides in stromatolites at Kokšín [29]; inclusions of clausthalite in wolframite from the Sn-W Krupka deposit [30]; and Bi-sulfoselenotellurides in products of burning of coal-mine dump at Radvanice near Trutnov [31].

The exceptional character of selenide occurrences in the Bohemian Massif is underlined by 18 newly-discovered selenide mineral species, out of a total of ca. 90 known selenide minerals. The new minerals include bukovite [32] and sabatierite [33] from the Bukov locality; bellidoite from Habří [34]; bohdanowiczite from Kletno in Poland [35]; poubaite [8] and součekite [9] from Oldřichov near Tachov; krut'aite [36] and petrovicite [37] from Petrovice; fischesserite [38], hakite [39], permingeatite [40], milotaite [41], and petř́ičekite from Předbořice [42]; mgriite [43] and schlemaite [44] from Schlema in Germany; litochlebite from Zálesí [45]; and příbramite [46] and bytízite [47] from Př́bram.

At the uranium and base-metal Prríbram ore district (the most important hydrothermal uranium district in the Czech Republic), clausthalite was originally reported as rare and local in its occurrence [48]. The first relatively important selenide occurrence was described on the basis of a preserved reference sample by Litochleb et al. [49]. The extraction of material from mine dumps at some Přibram uranium mines (in particular, shafts 16, 11A, and 9) provided the opportunity during the period of 2005-2015 to monitor selenium minerals in the mine dump material and obtain more samples for a complex mineralogical study of selenide mineral assemblages. The first partially-published results include clausthalite in association with arsenolamprite [50] and cuprostibite [51], permingeatite [52], S-rich antimonselite [53], hakite [54], přibramite [46], brodtkorbite [55], and bytízite [47]. A comprehensive study of the selenide mineralization at the Př́bram uranium base-metal ore district was the topic of a Ph.D. thesis of Škácha [56], and forms the basis of this paper. Empirical formulae of selenides and some associated sulphides are shown in Table S1.

\section{The Příbram Uranium and Base-Metal Ore District}

\subsection{History of Mining}

Two main ore districts are known in the Příbram ore area (Central Bohemia, Czech Republic). They include the Březové hory base-metals district and the Prríbram complex uranium and base-metals district (Figure 1), referred to as the "Příbram uranium district" in the following text. The Březové hory base-metal district-located in the western part of the area-was known from at least the 13th century, but the main mining activity took place from 1810 to 1978. A total of 22 million tonnes of extracted ore contained 3837 tonnes of silver, 517,961 tonnes of lead, and 70,300 tonnes of antimony [57].

The history of the easterly-positioned Prribram uranium district started in 1947 with the discovery of the first uranium anomalies. Mining started as early as 1948 with the opening of the first shafts (1 and 2, Vojna). In 1950, uranium exploitation started on a large scale. In succession, 26 shafts were constructed, which opened eight main deposits of the uranium district (Třebsko, Kamenná, Lešetice, Brod, Jerusalem, Háje, Bytíz, and Skalka). The deposits used to be historically designated as "vein nodes". 


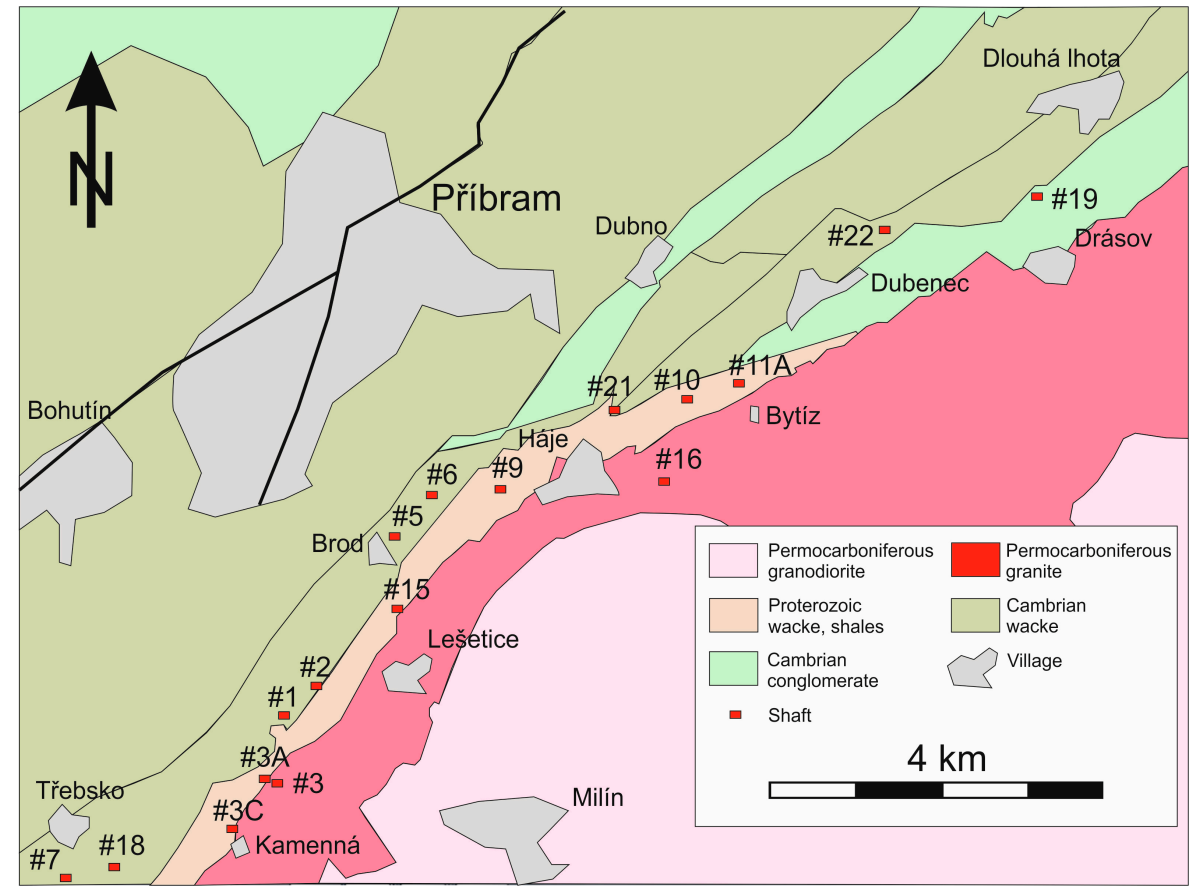

Figure 1. Simplified geological map of the main part of the Přibram uranium and base-metal district.

Uranium mining culminated there in 1975, when this ore district became the main producer of uranium ores in the former Czechoslovakia. In the following year, the final depth of $1838.4 \mathrm{~m}$ was reached in shaft 16 (Háje). At that time, this was the deepest ore mine, vertically, in Europe. Owing to a change in economic and political conditions in the former Czechoslovakia in 1989, the extraction of uranium ores in this ore district was terminated in 1991. The following numbers indicate the remarkable extent of the mine works in the Příbram uranium ore district: $23 \mathrm{~km}$ of vertical shafts, $2188 \mathrm{~km}$ of horizontal adits, and $300 \mathrm{~km}$ of chutes were created in an area of $57.6 \mathrm{~km}^{2}$ over 44 years (1948-1991). In the process, more than 2500 hydrothermal (especially carbonate) veins were exposed; the uranium mineralization occurred in 1641 veins, base metal mineralization in 35 veins, and finally, monomineralic silver mineralization in 19 veins [57]. The total production of $48,432 \mathrm{t}$ of pure $\mathrm{U}$ metal represented $49 \%$ of Czechoslovak production since 1945 . The parallel mining of base metals and silver from veins produced more than 6100 tonnes of $\mathrm{Pb}, 2400$ tonnes of $\mathrm{Zn}$, and 28 tonnes of $\mathrm{Ag}$ [58]. These data qualify the Př́bram uranium district for competition with the most important hydrothermal vein uranium districts on a worldwide scale.

\subsection{Geological Situation}

Both of the main ore districts (Březové Hory base-metals district and the Příbram uranium district) are situated near the southeastern contact of Barrandian sedimentary rocks of the Neoproterozoic and Lower Cambrian age, with the western margin of granitoids of the Central Bohemian Plutonic Complex. The Přibram uranium district is located tightly in the exocontact of the Central Bohemian Plutonic Complex in metasedimentary rocks of the Barrandian Unit. The uranium hydrothermal vein mineralization is located in a zone of tectonically-deformed Neoproterozoic rocks $1-2 \mathrm{~km}$ wide and $25 \mathrm{~km}$ long, including the Př́bram antiform [58]. A predominant part of uranium mineralization (96\%) occurred in veins located in the Dobřiš Group of Neoproterozoic age with a predominance of claystones, siltstones, and sandstones. The underlying Davle Group of tuffs and tuffites was encountered by two structural boreholes and by deep levels of mines in the Bytíz area. 
Lower Cambrian sediments-including conglomerates overlying the Dobřiš Group-were penetrated by numerous mines. This concerns the upper parts of the central and northeastern part of the ore district and at greater depth in the northern part of the vein Bt4. All rock types are affected by contact metamorphism caused by granitoids of the Central Bohemian Plutonic Complex [59]. Granitoids are represented here by the so-called marginal-type and Blatná-type granitoids. Mineralized veins wedge out upon reaching plutonic rocks.

There are four main mineralization stages generally identified in the Př́bram uranium district [59]: (I) siderite-sulphidic; (II) calcite; (III) calcite-uraninite; and (IV) calcite-sulphidic. The oldest siderite-sulphidic (stage I) is developed on a smaller scale in comparison with the neighbouring Březové Hory district. The younger calcite stages are characterized by notably lower temperatures, and are more abundant; calcite generations were used in separating mineralization stages. The calcite stage (II) is characterized by pre-ore calcite DK and calcite K1. In the calcite-uraninite stage (III) — carrying the main part of the industrial uranium mineralization (uraninite, coffinite, and U-bearing anthraxolite) —calcite types K2-K4 are present. In the last calcite-sulphidic stage (IV), post-ore calcite K5 appears.

The calcite-uraninite (stage III) and the youngest calcite-sulphidic (stage IV) stages are important for selenide mineralization. Selenide mineralization occurs in close association with uraninite of the calcite-uraninite mineralization, but selenides are always younger than uraninite. It is uncertain if selenides in Přibram originated in the conclusion of the calcite-uraninite stage, or at the beginning of the following calcite-sulphidic stage, which is mentioned by some authors [55].

The age of the uranium mineralization obtained by the U-Pb dating of uraninite showed the middle Permian ages of $275 \pm 4$ and $278 \pm 4$ Ma [60]. Uraninite from the nearby Březové Hory base-metal ore district has similar ages $(269.8 \pm 20.3$ and $263.2 \pm 8.9 \mathrm{Ma})$ [61]. According to the fluid inclusions study [62], the carbonate veins carrying uraninite in the Přibram uranium district formed at low-temperatures $\left(80-140^{\circ} \mathrm{C}\right)$ from low-salinity fluids. Other data indicate that fluids instrumental in the deposition of the uraninite-carbonate mineralization derived from local meteoric waters and evolved in the process of migration through upper crustal rocks [62].

\section{Methods of Research}

\subsection{Reflected Light Microscopy}

A Zeiss Stemi 2000C optical microscope (Jena, Germany) with a Canon 5DSR digital camera (Tokyo, Japan) (in the Příbram Mining Museum) was used for the study of sample morphology in reflected light. Samples for microscopy and the following laboratory study were prepared as polished sections $2.54 \mathrm{~cm}$ across, mounted in resin, and polished with diamond suspensions in the Diatech s.r.o. company, Prague, Czech Republic. Over 250 polished sections representing all types of vein filling were used.

Optical properties of minerals in reflected light were studied using a Nikon Eclipse ME600 microscope (Minato, Japan) at the National Museum, Prague, Czech Republic. Reflected light microphotos were prepared using a Nikon DXM1200F digital camera (Minato, Japan).

\subsection{Quantitative Analysis of Chemical Composition}

Chemical analyses were performed using a Cameca SX100 electron microprobe (Gennevilliers Cedex, France) (National Museum, Prague; P. Škácha, J. Sejkora and I. Macek as analysts) operating in WDS (wavelength-dispersive spectroscopy) mode ( $25 \mathrm{kV}, 20 \mathrm{nA}$, and $2 \mu \mathrm{m}$ wide beam). The following standards and X-ray lines were used to minimize line overlaps: $\operatorname{Ag}(\operatorname{AgL} \alpha), \operatorname{Au}(\mathrm{AuM} \alpha), \operatorname{Bi}(\operatorname{BiM} \beta)$, $\mathrm{CdTe}(\mathrm{CdL} \alpha)$, $\mathrm{Co}(\mathrm{CoK} \alpha)$, chalcopyrite $(\mathrm{CuK} \alpha), \mathrm{FeS}_{2}(\mathrm{FeK} \alpha, \mathrm{SK} \alpha), \operatorname{HgTe}(\mathrm{HgM} \alpha), \mathrm{NiAs}(\mathrm{NiK} \alpha, \mathrm{AsL} \alpha)$, $\mathrm{PbS}(\mathrm{PbM} \alpha), \mathrm{PbSe}(\mathrm{SeL} \alpha), \mathrm{PbTe}(\mathrm{TeL} \alpha), \mathrm{Sb}_{2} \mathrm{~S}_{3}(\mathrm{SbL} \alpha), \mathrm{Tl}(\mathrm{BrI})(\mathrm{Tl} \mathrm{L} \alpha)$, and $\mathrm{ZnS}(\mathrm{ZnK} \alpha)$. Peak counting times were $20 \mathrm{~s}$ for all elements and one-half of the peak time for each background. Contents of the above-listed elements (which are not included in tables) were analyzed quantitatively, but with 
contents below the detection limit (ca. 0.01-0.04 wt \% for individual elements). Raw intensities were converted to the concentrations of elements using automated "PAP" [63] matrix-correction software.

\subsection{X-Ray Powder Diffraction Methods (PXRD)}

In the first stage, small fragments of samples carrying selenides were dissolved in hydrochloric acid. Insoluble residues were washed with water and neutralized with $\mathrm{Na}_{2} \mathrm{CO}_{3}$. Small selenide aggregates submerged in water were mechanically separated according to colour and morphological properties of individual minerals.

Selected monomineral subsamples were used for diffraction data using a Bruker D8 Advance X-ray powder diffractometer (National Museum, Praha, Czech Republic) with a LynxEye semiconductor detector, using $\mathrm{CuK} \alpha$ radiation $(40 \mathrm{kV}, 40 \mathrm{~mA})$. Powder mounts were prepared with acetone suspension on a plate of monocrystalline silicon. X-ray data were recorded in a step-scanning manner (step $0.01^{\circ}$, time $30 \mathrm{~s} / \mathrm{step}$ of the detector; total time of experiment more than $50 \mathrm{~h}$ ). Positions of individual diffraction maxima were refined with a Pearson VII profile function in the ZDS program for DOS [64]. Indices hkl were assigned based on tabulated theoretical values calculated from available structural data with the Lazy Pulverix program [65]. Lattice parameters for individual minerals were refined using Burnham program [66].

\subsection{Single-Crystal X-ray Diffraction Methods (SXRD)}

Single-crystal diffraction experiments were done using a Rigaku Oxford diffraction SuperNova diffractometer (Tokyo, Japan) equipped with an Atlas S2 CCD detector. Mirror-monochromatized $\operatorname{MoK} \alpha$ radiation $(\lambda=0.71073 \AA)$ from a microfocus $X$-ray source was utilized. Unit-cell parameters were refined from the diffraction data employing least-squares algorithm within the CrysAlis Pro program package (Rigaku).

\subsection{Electron Backscatter Diffraction (EBSD)}

For checking the identity of the crystal structure of selected minerals with a presumed structure model, the EBSD method (electron backscatter diffraction) was used. The surface of the sample in the polished section was treated by chemical polishing, using amorphous $\mathrm{SiO}_{2}$ in suspensions with successively acidic and alkaline $\mathrm{pH}$.

Measurements were conducted with a Tescan Vega (Brno, Czech Republic) scanning electron microscope (Faculty of Science, Charles University, Praha), operated by M. Racek. The apparatus was equipped with a NordlysNano EBSD detector (Oxford Instruments, Abingdon-on-Thames, UK). The following operating conditions were used: accelerating voltage of $20 \mathrm{kV}$, beam current ca. $7 \mathrm{nA}$, the area of the analysed sample (diameter of the area for signal collecting) less than ca. $1 \mu \mathrm{m}$, and tilted by $70^{\circ}$ from horizontal. Data obtained were registered and processed using Channel5 software (Oxford Instruments, Abingdon-on-Thames, UK); data for the structural model (unit-cell parameters, space group, and atoms and their co-ordinates in the elementary cell) were downloaded from the crystal structure refinements cited in the discussion of the individual minerals below.

\subsection{Raman Spectroscopy}

Raman spectra of mineral phases in polished sections were collected in the range $30-3500 \mathrm{~cm}^{-1}$ using a DXR dispersive Raman spectrometer (Thermo Scientific, Waltham, MA, USA) mounted on a confocal Olympus microscope (National Museum, Prague, Czech Republic). The Raman signal was excited by a green $532 \mathrm{~nm}$ diode-pumped solid-state laser and detected by a CCD detector. The experimental parameters were: $50 \times$ objective, 1 s exposure time, 1000 exposures, 900 lines $/ \mathrm{mm}$ grating, $50 \mu \mathrm{m}$ slit spectrograph aperture, and $0.5 \mathrm{~mW}$ laser power level. The instrument was set up by a software-controlled calibration procedure using multiple neon emission lines (wavelength calibration), multiple polystyrene Raman bands (laser frequency calibration), and standardized 
white-light sources (intensity calibration). Spectral manipulations were performed using Omnic 9 software (Thermo Scientific).

\section{Results}

\subsection{Characterization of Selenide Occurrences in Přibram}

R $u$ žička [48] recorded the first occurrence of selenium mineralization in the Přibram uranium district by describing clausthalite from vein Bt4 at the Bytíz deposit. Later on, selenides were identified in documentation samples (deposited in the National Museum, Praha) from vein Bt 22B, 4th level, north [49]. In the course of the continued research of documentation, a sample carrying uraninite was located with another sample containing small accessory aggregates of selenides. This sample came from the Bt 4 vein, 8th level, north, corresponding to the depth of $450 \mathrm{~m}$. Due to the sampling period, the documentation set did not contain samples from deeper levels of the deposit. This might indicate that the selenium mineralization is developed only in the uppermost part of the district. However, the considerable distribution of the selenide mineralization in the dumps at shafts 16 and $11 \mathrm{~A}$, and the overall relative abundance of material with selenides, supports the alternative of a deeper vertical extent of the selenide mineralization-at least at the Bytíz deposit. Several additional samples with selenides were found at the dump of shaft 9 (Jerusalem), used for the exploitation of veins in the upper part of the Jerusalem deposit.

Samples used in the present study were collected at the dumps at shafts 9 (Jerusalem), 16 (Háje near Přibram), and 11A (Bytíz). Dumps at shafts 16 (Figure 2A) and 11A (Figure 2B) were recently intensively processed by the Ecoinvest Company for the production of crushed aggregate, in part as a construction material for the D3 highway. Continued exploitation and technical separation of dispersed radioactive material made sample collection from the lower parts of dump 16 (Háje near Přibram) and parts of the dump 11A (Bytíz) possible.
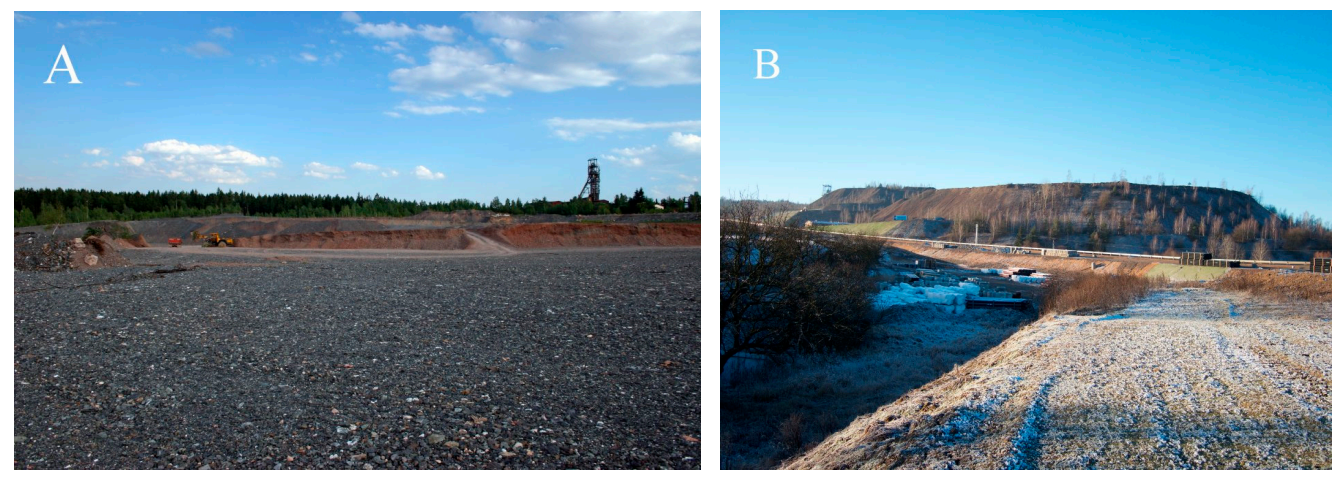

Figure 2. Dump of the shaft (A) 16-Háje in 2007 and (B) 11A-Bytíz in 2017. Photos by P. Škácha.

The possible occurrence of material with selenide mineralization was checked at some other dumps using a sensitive scintillation detector. This included dumps at some other shafts of the Přibram uranium district (Figure 1)—in particular, shafts 2 (Vojna), 4 (Lešetice), 3C (Kamenná), 5, 6, 15 (Brod), and 19 (Dubenec). No additional selenide occurrences were found in the course of this field work. This negative result does not necessarily prove the absence of selenide, as the recultivated surface of the dumps presents adverse conditions for sample collection. Local radioactive anomalies on the surface of the dumps were subject to controls and material collection at the time of mine operation, and later attracted the attention of private mineral collectors.

At the Březové Hory ore district, bordering at the west of the Př́bram uranium district, no selenide occurrences were found, although some local occurrences of uranium minerals are known. A single indication of a possible presence of selenides in this ore district is the report of supergene copper and lead selenate munakataite in several samples collected at a dump of the Lill mine [67]. 


\subsection{Characteristics of Individual Minerals of the Selenide Association}

\subsubsection{Antimonselite $\mathrm{Sb}_{2} \mathrm{Se}_{3}$}

Antimonselite was found at the dump of the mine 16, Háje near Příbram [53]. It forms euhedral acicular crystals up to $1.5 \times 0.1 \mathrm{~mm}$ (Figure 3 ). The crystals are enclosed in calcite gangue in association with uraninite, hakite, clausthalite, Se-rich chalcostibite, tiemannite, permingeatite, luzonite, tennantite, dzharkenite, and přibramite (Figure 4). Antimonselite is among the youngest minerals in the studied polished sections. The crystals are brittle, with perfect (010) cleavage. In the reflected light, antimonselite is white and shows bireflection. Under crossed polarizers, it is distinctly anisotropic. X-ray powder diffraction data for Př́bram antimonselite are given by Škácha et al. [53], including refined unit-cell parameters: $a=11.7437(6), b=3.9358(7), c=11.5846(8) \AA, V=535.4(1) \AA^{3}$. Based on single-crystal X-ray data, Škácha et al. [53] solved the crystal structure of the studied antimonselite. Based on the data (3353 reflections), refined unit-cell data were obtained using the least-squares algorithm of CrysAlis Pro [68] as follows: $a=11.7156(3), b=3.9514(11), c=11.5645(3) \AA$, $\mathrm{V}=535.36(15) \AA^{3}, \mathrm{Z}=4$. The obtained volume of the unit-cell of antimonselite from Přibram is compared with the published data for members of the stibnite-antimonselite solid solution in Figure 5.

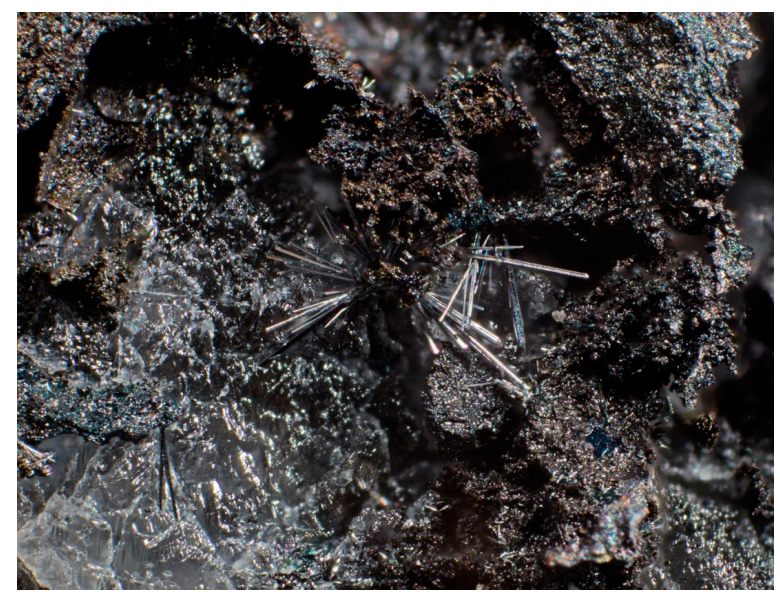

Figure 3. Antimonselite prismatic crystals partly etched from calcite. Field of view (FOV) $2.0 \mathrm{~mm}$. Photo by P. Škácha.

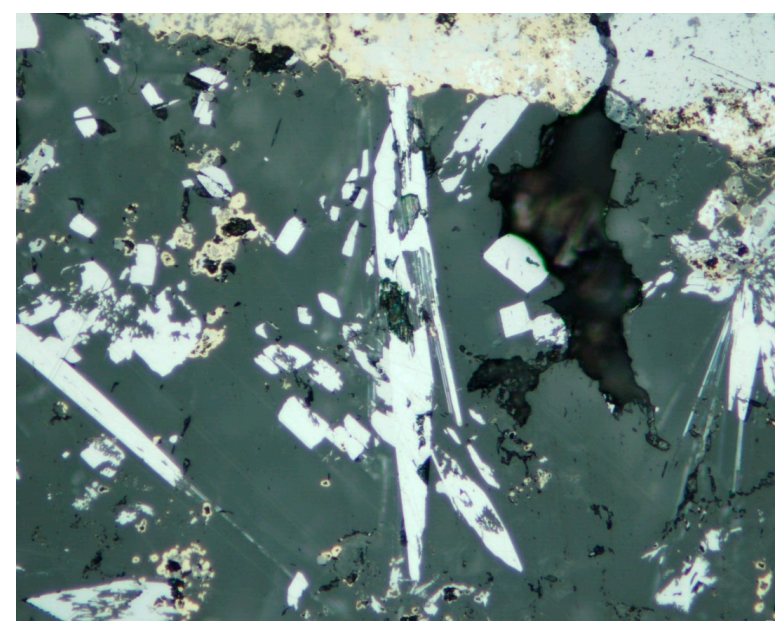

Figure 4. Antimonselite prismatic crystals and their rhombic sections in association with yellow chalcopyrite and grey tetrahedrite. Reflected light, one polarizer. Field of view $210 \mu \mathrm{m}$. Přibram, a dump of the shaft 16. Photo by P. Škácha. 


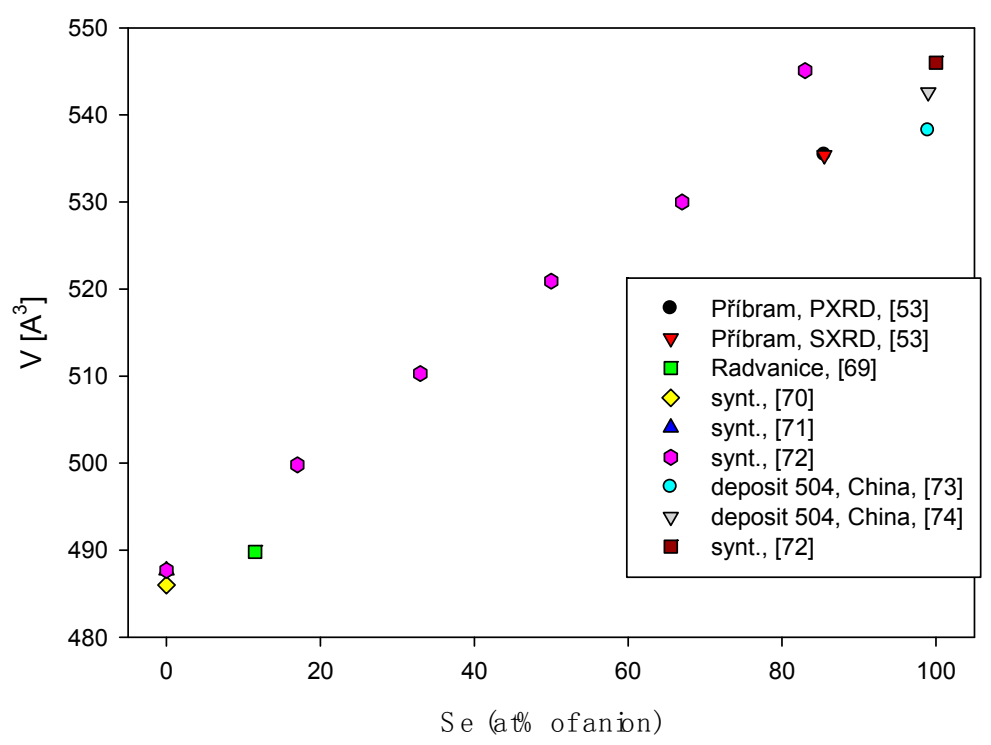

Figure 5. Se contents (at \% of anion) vs. the unit-cell volume graph for the members of the stibnite-antimonselite solid solution. PXRD: X-ray powder diffraction; SXRD: single crystal X-ray diffraction [69-74].

In the course of the chemical study of newly-polished sections of antimonselite (Table S2), minor sulphur contents in the range of 0.03-0.16 apfu were found in addition to the dominant Se. Škácha et al. [53] determined slightly higher sulphur contents in the range 0.31-0.56 apfu. Similar $\mathrm{S}$ contents have been reported for some samples from Chinese localities La'erma and Qiongmo by Liu et al. [75]. The study of a synthetic stibnite-antimonselite series [72] shows a complete miscibility (Figure 6). Among cations, the dominant $\mathrm{Sb}$ is substituted by minor $\mathrm{Cu}$ contents below 0.02 apfu. The average empirical formula of Přibram antimonselite calculated on the basis of 5 apfu for 16-point analyses (including those in Škácha et al. [53]) is $\left(\mathrm{Sb}_{2.06} \mathrm{Cu}_{0.02}\right)_{\Sigma 2.08}\left(\mathrm{Se}_{2.67} \mathrm{~S}_{0.25}\right)_{\Sigma 2.92}$.

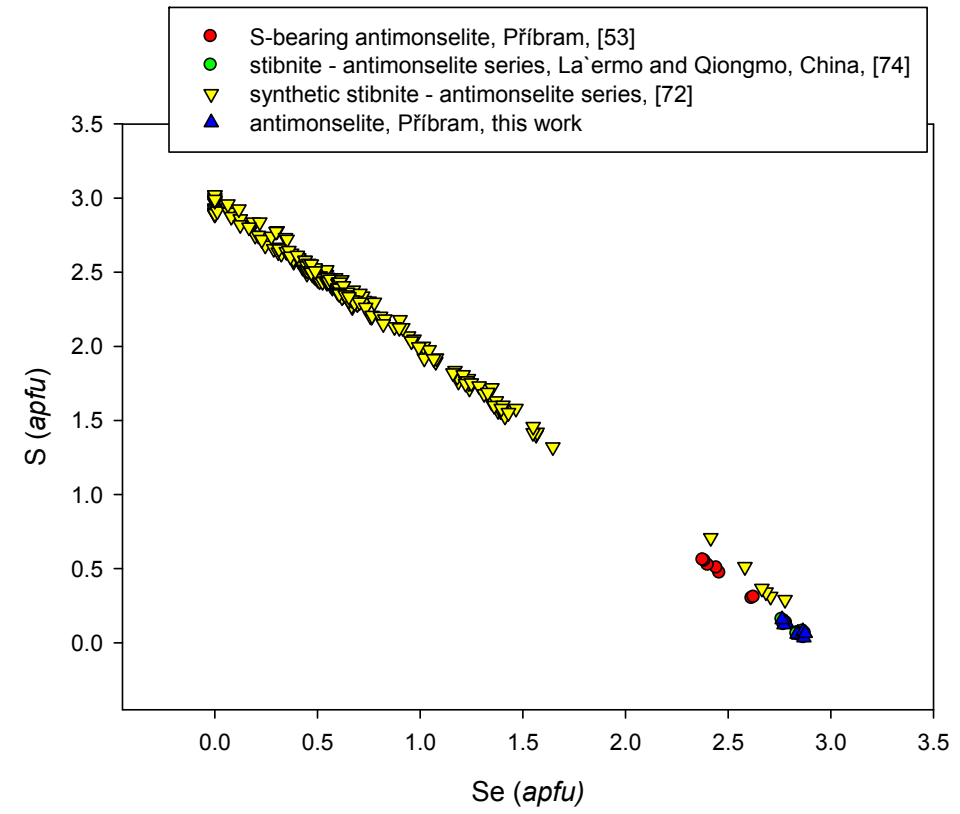

Figure 6. Se vs. S (apfu) graph of antimonselite from various localities. 


\subsubsection{Athabascaite $\mathrm{Cu}_{5} \mathrm{Se}_{4}$}

In the studied assemblage, athabascaite is a relatively rare mineral. It forms up to $300 \mu \mathrm{m}$ long anhedral aggregates composed of very thin lamellar crystals (Figure 7). Owing to its blue color, the mineral is very similar to berzelianite. Athabascaite is intergrown with umangite, and a local intergrowth with eucarite occurs. In addition, athabascaite is closely associated with Hg-hakite and uraninite. At the type locality Martin Lake Mine, Saskatchewan, Canada, athabascaite occurred as inclusions in umangite and as pseudomorphs after umangite was enclosed in gangue calcite. Several of the lath-shaped crystals show remnant cores of umangite that is finer-grained than the surrounding material, suggesting that the athabascaite is an alteration product of former umangite [76]. Umangite cores enclosed in athabascaite were also observed in samples from Př́bram (Figure 7).

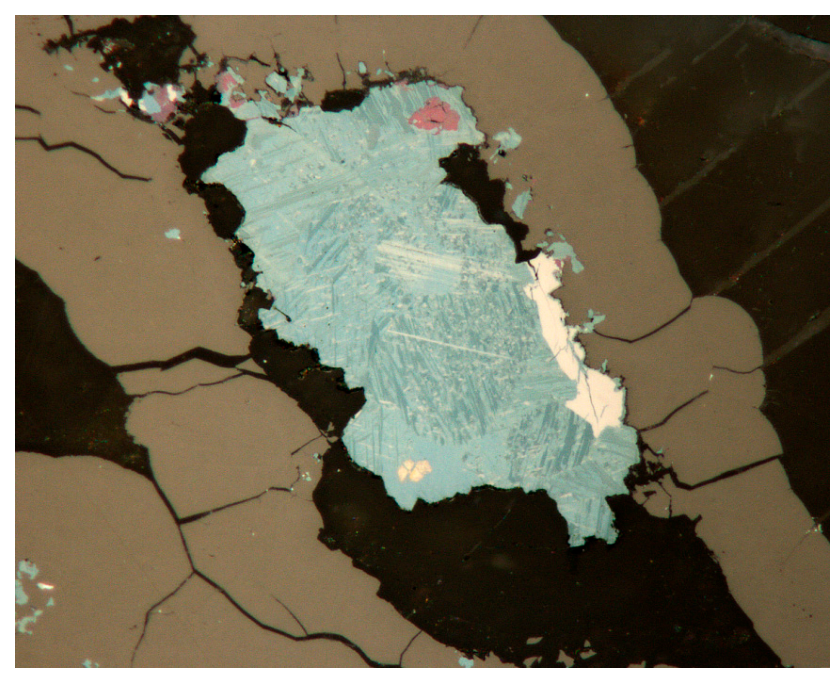

Figure 7. Whitish to dark blue (pleochroism colors) aggregate of athabascaite with creamy white eucairite and very small violet umangite grains. The dark brown uraninite rim surrounds the periphery. Reflected light, one polarizer. Field of view $210 \mu \mathrm{m}$. Přibram, a dump of the shaft 16 . Photo by P. Škácha.

In reflected light, athabascaite is grey-blue, and shows distinct bireflectance with color ranging from yellow-grey to blue-grey. Anisotropy is strong with colors changing from cream white to dark grey.

The chemical composition of athabascaite from Přibram (Table S3) is represented by cation/anion ratio in the range 1.10-1.37 (based on 44 analyses). The studied mineral grain is probably forming very fine intergrowths with other $\mathrm{Cu}$ selenides or sulphides, and this may be the reason for the observed non-stoichiometry. The cation part of the formula contains minor Ag (up to $0.14 \mathrm{apfu}$ ), and locally, Fe (up to $0.36 \mathrm{apfu}$ ), in addition to the dominant $\mathrm{Cu}$. The anion part features a significant $\mathrm{SeS}_{-1}$ isomorphism; sulphur contents attain up to 1.14 apfu (Figure 8)-i.e., contents higher than values reported for this mineral in the literature $[14,49,76,77]$. Additionally, a locally-significant Te content up to 0.16 apfu was rarely observed. The empirical formula for studied athabascaite on the basis of 9 apfu (average of 44 point analyses) can be expressed as $\left(\mathrm{Cu}_{4.98} \mathrm{Fe}_{0.06} \mathrm{Ag}_{0.03}\right)_{\Sigma 5.07}\left(\mathrm{Se}_{3.12} \mathrm{~S}_{0.80} \mathrm{Te}_{0.01}\right)_{\Sigma 3.93}$. 


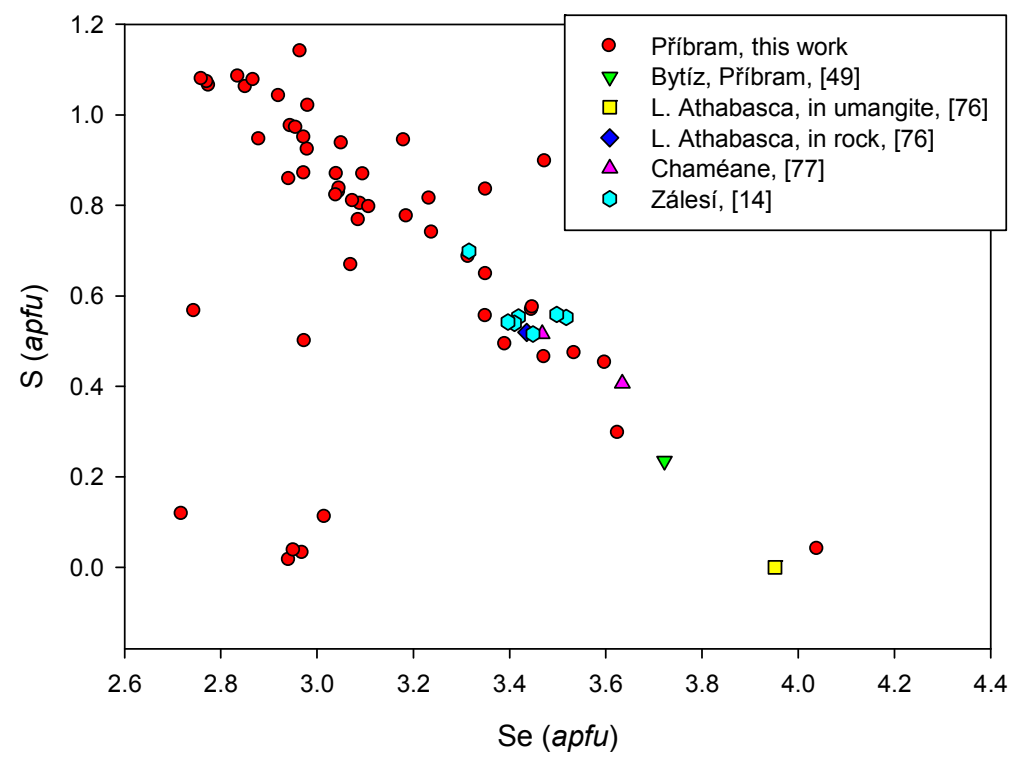

Figure 8. Se vs. S (apfu) graph of athabascaite from various localities.

\subsubsection{Bellidoite $\mathrm{Cu}_{2} \mathrm{Se}$}

Bellidoite is an extremely rare selenide so far reported only from Habří (Czech Republic), Tumiñico (Argentina), El Dragón (Bolivia), and Jiguanzui and Jilongshan (China) [34,78-80]. Its occurrence in the Přibram uranium district is in the samples with abundant berzelianite, umangite, and eucairite, confirmed by X-ray powder diffraction.

In reflected light, bellidoite is creamy white (Figure 9). Anisotropy was not observed.
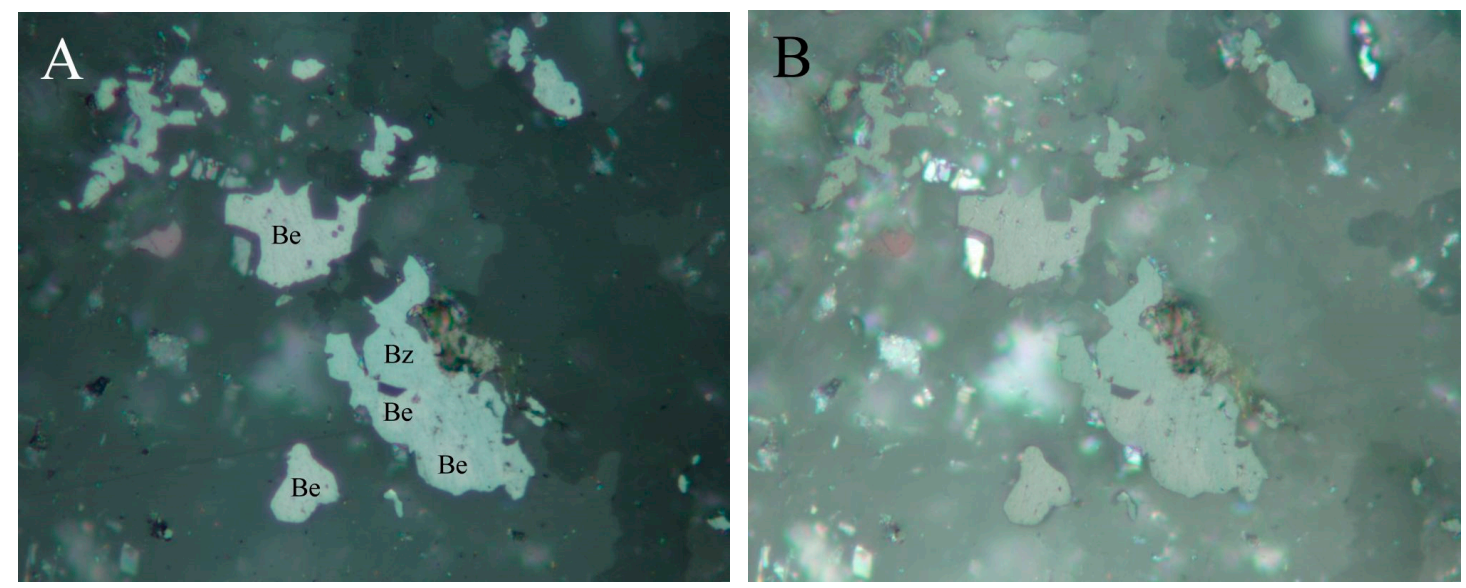

Figure 9. Bellidoite (Be) euhedral grains in association with bluish berzelianite (Bz). Reflected light, (A) one polarizer, and (B) partly-crossed polarizers. Field of view $210 \mu \mathrm{m}$. Př́ibram, from a dump of shaft 16. Photo by P. Škácha.

Bellidoite identification in polished sections is made difficult at first sight by the similarity of the optical properties of bellidoite to those of berzelianite in small sizes of grains and their intergrowths. In addition, berzelianite and bellidoite often form very close intergrowths, and the size of individual grains is under $1 \mu \mathrm{m}$. Eucairite-and especially berzelianite-are rather abundant in the studied assemblage.

The X-ray powder diffraction data of bellidoite from Prribram (Table S4) agree very well with the published data of this mineral phase [34]. Due to the unknown crystal structure of bellidoite, 
the experimental pattern (selected maxima of bellidoite in a mixture with berzelianite and eucairite) was indexed on the base of a tetragonal $\left(P 4_{2} / n\right)$ unit-cell with an $=11.52$ and $c=11.74 \AA$, proposed by Montreuil [34]. The refined unit-cell parameters of bellidoite from Př́bram are an $=11.607(7)$, $\mathrm{c}=11.74(1) \AA$, and $\mathrm{V}=1582(2) \AA^{3}$.

The chemical composition of Přibram bellidoite may be partly affected by its intimate intergrowth with berzelianite (Figure 10). The cation part of the formula contains Ag (0.00-0.02 apfu) and Fe (0.00-0.06 apfu); in anion parts, only a minor S content was observed (0.00-0.01 apfu) (Table S5). Very low $\mathrm{S}$ content is typical for this phase according to the published data [34]. The empirical formula of Přibram bellidoite (from an average of 109 analyses) based on 3 apfu is $\mathrm{Cu}_{1.96}\left(\mathrm{Se}_{1.00} \mathrm{~S}_{0.03}\right)_{\Sigma 1.03}$.

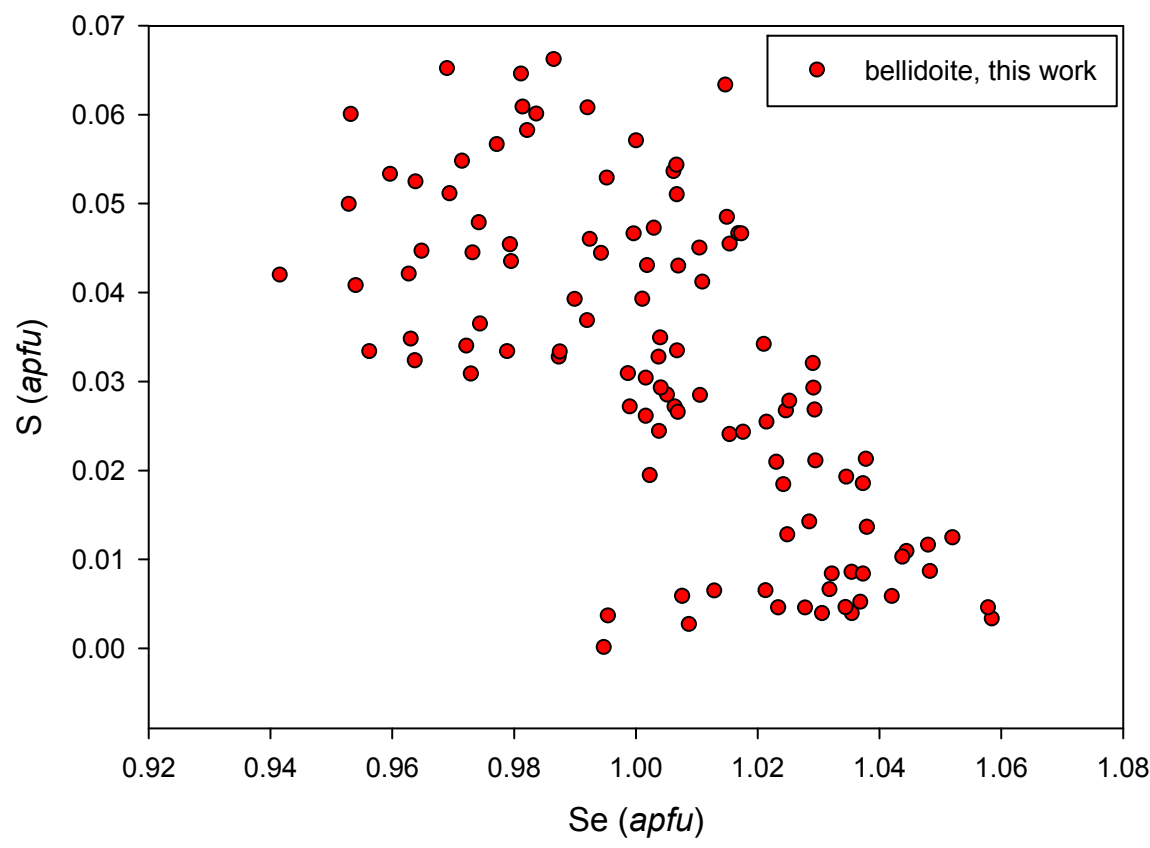

Figure 10. Se vs. S (apfu) graph for bellidoite from Příbram.

\subsubsection{Berzelianite $\mathrm{Cu}_{2-x} \mathrm{Se}$}

Berzelianite belongs among the most abundant selenides at the deposit. It forms typical blue to blue-green anhedral aggregates in calcite gangue. Berzelianite aggregates rarely exceed $2 \mathrm{~mm}$. The mineral was observed as inclusion in uraninite and as abundant rims separating carbonate generations. It was frequently identified in the proximity of massive uraninite veins, in thin veinlets in the adjacent carbonate, or directly in uraninite (Figure 11). The presence of berzelianite in carbonate-uraninite vein filling deposited at dumps is indicated by abundant malachite coatings formed by the recent weathering of berzelianite. Berzelianite aggregates often show replacement by umangite, starting in the center of aggregates. Overgrowth of berzelianite aggregates by chalcopyrite is rare (Figure 12). The association of berzelianite with Hg-hakite is typical (Figure 13). In reflected light, isotropic berzelianite has a steel grey-blue color. X-ray powder data for berzelianite (Table S6), as well as the refined parameters of the unit-cell (Table S7), correspond well to the data published for this mineral. 


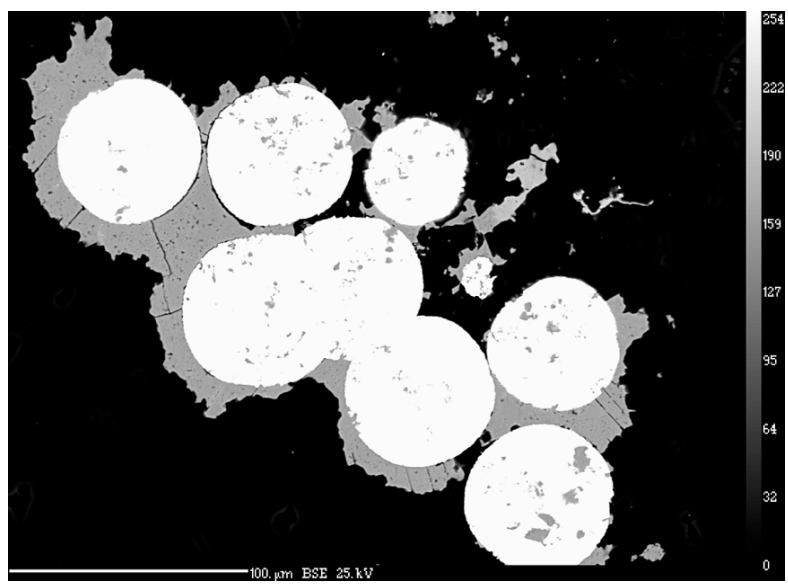

Figure 11. Spherical aggregates of uraninite (white) overgrown by later berzelianite (grey). Backscattered electron (BSE in the further text) photo. Př́bram, a dump of shaft 16. Photo by J. Sejkora and P. Škácha.

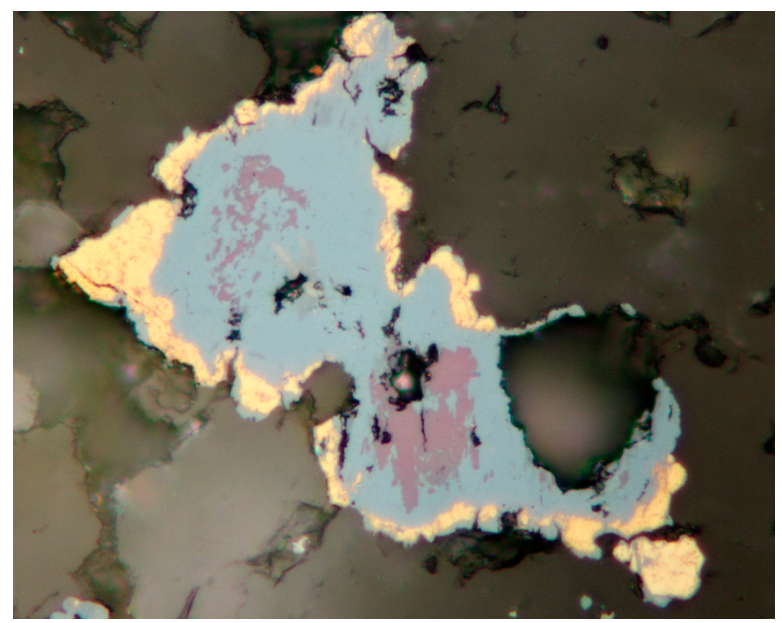

Figure 12. Earlier berzelianite (blue) with umangite (violet) inclusions replaced by later chalcopyrite (yellow). Reflected light, one polarizer. FOV $525 \mu \mathrm{m}$. Příbram, a dump of shaft 16. Photo by P. Škácha.

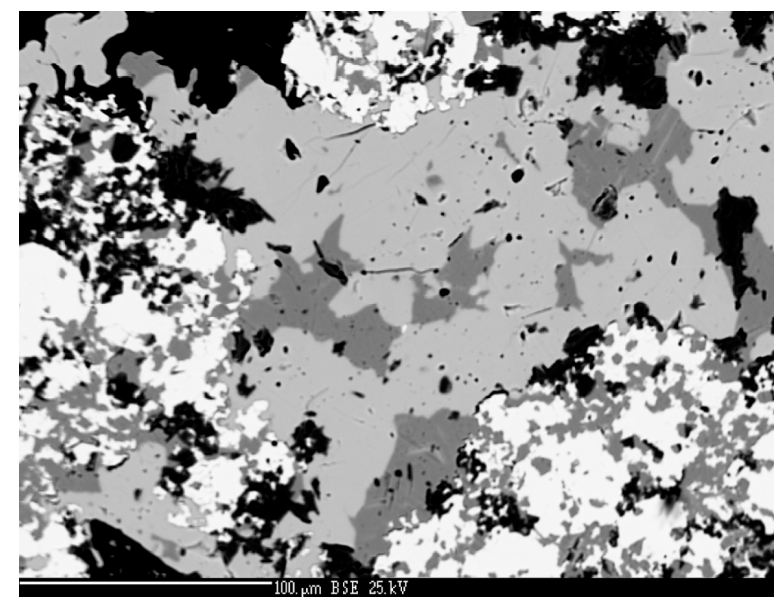

Figure 13. Berzelianite aggregates (dark grey) in Hg-hakite (light grey) in association with uraninite (white). BSE photo. Příbram, a dump of shaft 16. Photo J. Sejkora and P. Škácha. 
The X-ray powder diffraction data were obtained for two types of berzelianite from Příbram (Table S6). The pattern of berzelianite (S-poor) agrees very well with the data calculated from the crystal structure information [81]; the positions of diffraction maxima of S-rich berzelianite are shifted to lower $2 \theta$ angles. The refined unit-cell parameters are given in Table S7; the increased content of $S$ results in a decrease of the berzelianite unit-cell volume.

Study of the chemical composition of S-poor berzelianite (Table S8) and S-rich and S + Te-rich berzelianite (Table S9) results in cation/anion ratios in the range of 1.62-1.94 (Figure 14). This value may include - besides non-stoichiometry of the mineral—the effect of intergrowth with other $\mathrm{Cu}$-selenides on a sub-microscopic scale. We can distinguish three chemical types of berzelianite: normal S-poor berzelianite, S-rich berzelianite, and S, Te-rich berzelianite. The most common are S-poor berzelianite and much rarer S-rich berzelianite, in association with arsenic and arsenolamprite, or with chalcocite and S-rich umangite was found. S, Te-rich berzelianite was found only in one case in association with Te-tiemannite. For all three types, the cation part of the formula (except the dominant $\mathrm{Cu}$ ) frequently contains minor silver (up to $0.03 \mathrm{apfu}$ ), and in the case of S-poor berzelianite and S-rich berzelianite, local Fe content up to $0.07 \mathrm{apfu}$ and $\mathrm{Hg}$ content up to $0.004 \mathrm{apfu}$ were found. The anion part exhibits isomorphic substitution of Se by S (up to $0.51 \mathrm{apfu}$ ) in the case of S-rich berzelianite and rarely by Te (up to $0.06 \mathrm{apfu}$ ), together with S (up to $0.19 \mathrm{apfu}$ ). Sulphur contents in berzelianite from various localities are reported in Figure 14. For the first time, such samples, containing up to $1.24 \mathrm{~S}$ apfu, were reported from Martin Lake (Canada) by Harris et al. [82]. Litochleb et al. [49] mentioned elevated sulphur contents up to $0.22 \mathrm{apfu}$ for a sample from the Bytíz deposit. We have found no reports on Te content in berzelianite in the literature. The empirical formula for S-poor berzelianite, $\mathrm{Cu}_{1.93}\left(\mathrm{Se}_{1.02} \mathrm{~S}_{0.05}\right)_{\Sigma 1.07}$, is based on 4 apfu and an average of 165 analyses. The empirical formula for S-rich berzelianite, $\left(\mathrm{Cu}_{1.88} \mathrm{Fe}_{0.03}\right)_{\Sigma 1.91}\left(\mathrm{Se}_{0.69} \mathrm{~S}_{0.43}\right)_{\Sigma 1.12}$, is based on $4 a p f u$ and an average of 52 analyses. The empirical formula for $\mathrm{S}$, Te-rich berzelianite, $\mathrm{Cu}_{1.94}\left(\mathrm{Se}_{0.85} \mathrm{~S}_{0.14} \mathrm{Te}_{0.06}\right)_{\Sigma 1.05}$, is based on 4 apfu and an average of four analyses.

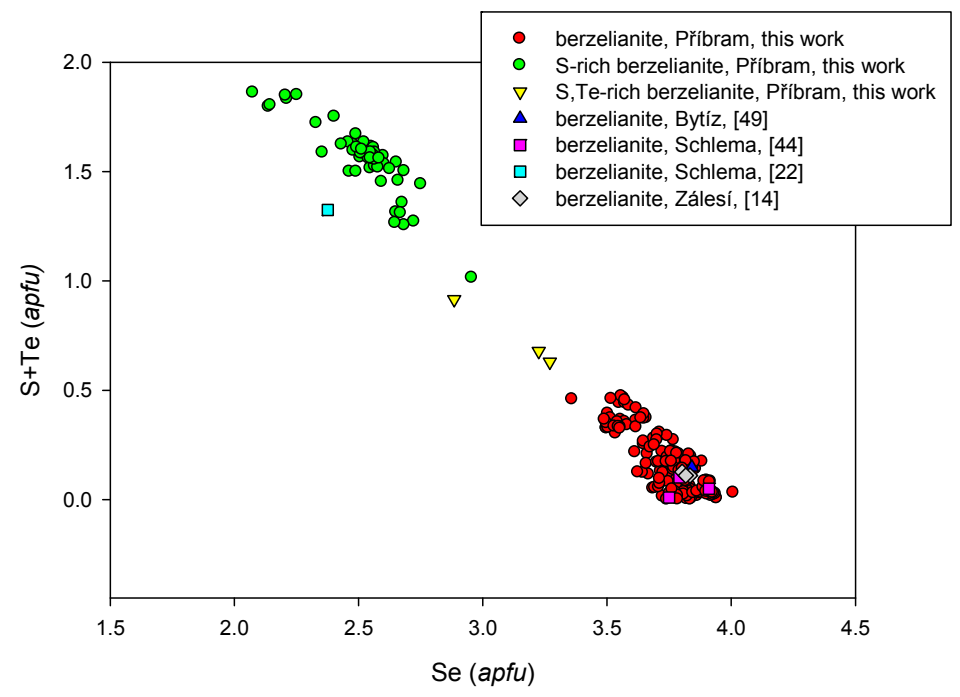

Figure 14. Se vs. S+Te (apfu) graph in berzelianite from various localities.

\subsubsection{Brodtkorbite, $\mathrm{Cu}_{2} \mathrm{HgSe}_{2}$}

Brodtkorbite is an extremely rare selenide known only from the type locality Tumiñico in Argentina [79]. In Příbram, brodtkorbite was identified in carbonate gangue carrying abundant tiemannite, berzelianite, and other selenides [55]. It occurs as anhedral aggregates up to $150 \mu \mathrm{m}$ across in intergrowth with tiemannite (Figure 15), clausthalite, and eucairite, and contains uraninite inclusions of a spheroidal shape. Relatively abundant lamellar intergrowth of tiemannite and umangite represents the most probable products of brodtkorbite disintegration (Figure 16). 


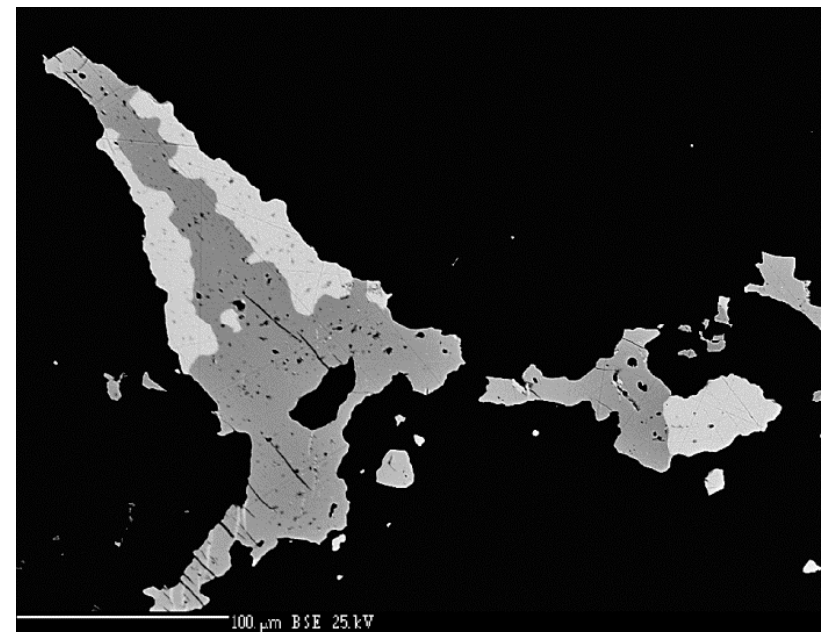

Figure 15. Brodtkorbite grains (grey) in association with tiemannite (white) in calcite gangue. BSE photo. Příbram, a dump of shaft 16. Photo by J. Sejkora.

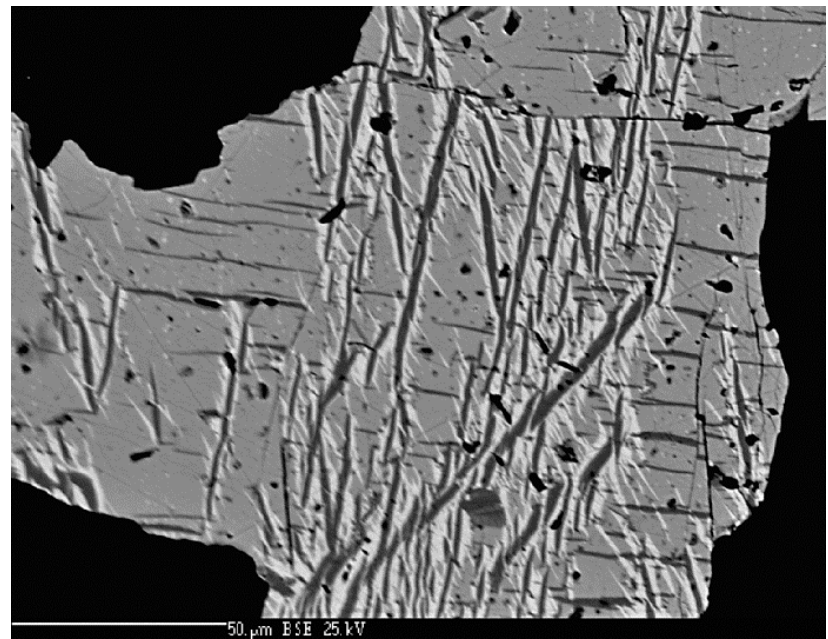

Figure 16. Brodtkorbite aggregates (grey) partly disintegrated to umangite (dark grey) and tiemannite (white). BSE photo. Př́bram, a dump of shaft 16. Photo by J. Sejkora.

In the reflected light, the mineral has properties similar to the type of material described by Paar et al. [79]. It is cream white with a light pink or bluish shade, somewhat darker than the associated tiemannite. It is strongly anisotropic, with colors under crossed polarizers changing from violet grey to yellow grey. Brodtkorbite is older than tiemannite, which replaces it along fractures.

X-ray powder diffraction data for Př́bram brodtkorbite are given by Sejkora et al. [55], including refined unit-cell parameters: $a=7.5137(5), b=4.1840(2), c=8.0183(6) \AA, \beta=124.394(3)^{\circ}$, $\mathrm{V}=208.01(4) \AA^{3}$. Based on single-crystal X-ray data, Sejkora et al. [55] solved the crystal structure of the studied brodtkorbite $\left(R_{\mathrm{obs}}=0.0805\right)$. Based on the data (416 reflections), refined unit-cell data were obtained using the CrysAlis Pro [68] program: $a=7.505(1), b=4.1851(9), c=8.013(1) \AA, \beta=124.43(2)^{\circ}$, with $\mathrm{V}=207.59(8) \AA^{3}, \mathrm{Z}=2$.

The chemical composition of Přibram brodtkorbite is relatively uniform. In addition to the main elements- $\mathrm{Hg}, \mathrm{Cu}$, and Se (Table S10)—were observed minor contents of $\mathrm{S}$ up to 0.02 apfu, Te to $0.01 \mathrm{apfu}$, and Ag up to $0.01 \mathrm{apfu}$. Different from the type material from Tumiñico [79], the studied brodtkorbite from Příbram does not contain trace amounts of Fe. The empirical formula of Příbram brodtkorbite (the mean of 19 analyses) based on 5 apfu is $\left(\mathrm{Cu}_{1.80} \mathrm{Ag}_{0.01}\right)_{\Sigma 1.81} \mathrm{Hg}_{1.11}\left(\mathrm{Se}_{2.07} \mathrm{~S}_{0.01}\right)_{\Sigma 2.08}$. 


\subsubsection{Bukovite, $\mathrm{Tl}_{2}(\mathrm{Cu}, \mathrm{Fe})_{4} \mathrm{Se}_{2}$}

Bukovite belongs among the rare selenides at the deposit, together with sabatierite and crookesite as other selenides containing $\mathrm{Tl}$ in its crystal structure. It occurs as lath-shaped crystals up to $30 \mu \mathrm{m}$ long, intergrown with uraninite and tiemannite in association with eucairite (Figure 17). It was also identified as $20 \mu \mathrm{m}$ euhedral crystals intergrown with sabatierite, or Zn-hakite, eskebornite, and umangite (Figure 18).

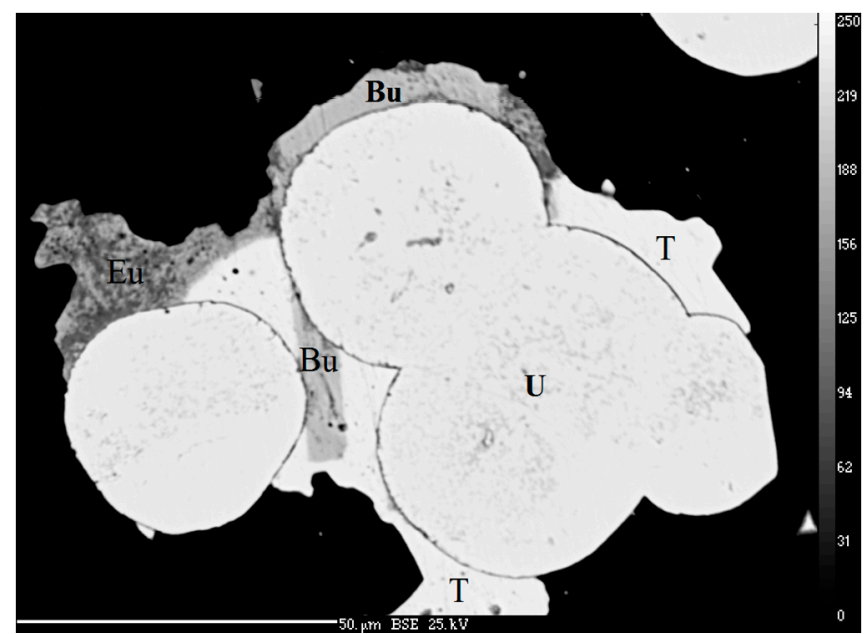

Figure 17. The euhedral aggregate of bukovite $(\mathrm{Bu})$ overgrowing with eucairite $(\mathrm{Eu})$ and tiemannite (T) earlier spherical aggregates of uraninite (U). BSE photo. Př́bram, a dump of shaft 16. Photo by J. Sejkora, P. Škácha.

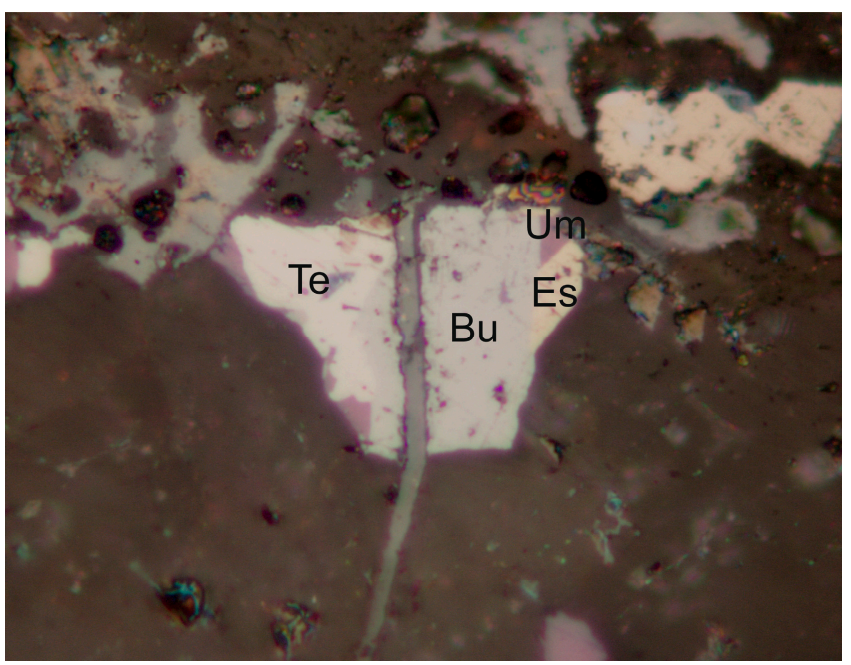

Figure 18. Grey bukovite growing with brownish eskebornite, violet umangite, and grey Zn-hakite. Reflected light, one polarizer. FOV $90 \mu \mathrm{m}$. Přibram, a dump of shaft 16. Photo by P. Škácha.

The mineral is light grey in reflected light, and weak anisotropy was observed.

The chemical composition of bukovite is relatively homogeneous (Table S11); identified were minor abundances of $\mathrm{Ag}$ (up to $0.20 \mathrm{apfu}$ ), $\mathrm{Pb}$ (up to $0.01 \mathrm{apfu}$ ), and S (up to $0.20 \mathrm{apfu}$ ). Specimens from the type locality [83] carry slightly increased $\mathrm{Ag}$ and $\mathrm{Pb}$. The chemical composition of bukovite from Prribram (average of 17 analyses), based on $10 \mathrm{apfu}$, can be expressed by the empirical formula $\left(\mathrm{Tl}_{1.95} \mathrm{~Pb}_{0.01}\right)_{\Sigma 1.96}\left(\mathrm{Cu}_{3.00} \mathrm{Ag}_{0.04}\right)_{\Sigma 3.04} \mathrm{Fe}_{0.97}\left(\mathrm{Se}_{3.96} \mathrm{~S}_{0.05} \mathrm{Te}_{0.01}\right)_{\Sigma 4.02}$. 


\subsubsection{Bytízite, $\mathrm{Cu}_{3} \mathrm{SbSe}_{3}$}

Bytíze is a rare new mineral described recently from one sample from a dump of shaft 16 by Škácha et al. [47]. Bytízite forms anhedral grains up to $40 \mu \mathrm{m}$ (in the section), growing together in aggregates up to $300 \mu \mathrm{m}$ across in the calcite gangue. Chaméanite, bukovite, príbramite, eskebornite, giraudite, umangite, crookesite, hakite, and tetrahedrite were found in the association.

Bytízite is steel-grey in colour and has a metallic lustre. In reflected light, bytízite is grey with a yellowish hue and weak bireflectance. Pleochroism is weak. Anisotropy under crossed polarisers is strong (Figure 19), with grey to brownish rotation tints.

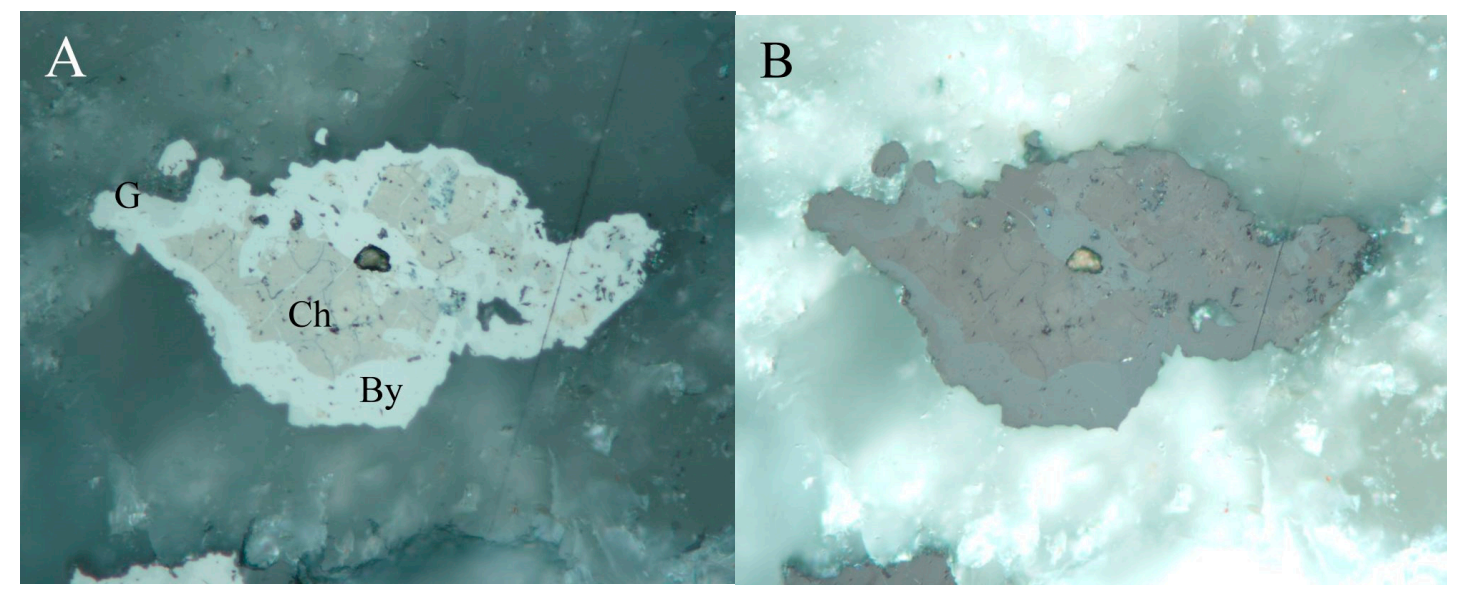

Figure 19. Light grey bytízite (By) forms a rim around brown chaméanite (Ch) with tiny light brown eskebornite inclusions. Dark grey giraudite $(G)$ is in the association. Reflected light, (A) one polarizer, and (B) partly-crossed polarizers. FOV $210 \mu \mathrm{m}$. Přibram, a dump of shaft 16. Photo by P. Škácha.

Bytízite is steel-grey in color and has a metallic lustre. In reflected light, bytízite is grey with a yellowish hue and weak bireflectance. Pleochroism is weak. Anisotropy under crossed polarizers is strong (Figure 19), with grey to brownish rotation tints.

X-ray powder diffraction data for Př́bram bytízite are given by Škácha et al. [47], including refined unit-cell parameters: $a=7.94(1), b=10.55(3), c=6.84(1) \AA, V=573(1) \AA^{3}$. Based on the single-crystal X-ray data, Škácha et al. [47] solved the crystal structure of bytízite $\left(R_{o b s}=0.0437\right)$. Based on the data (590 reflections), refined unit-cell data were obtained using the CrysAlis Pro program [60]: $a=7.959(1)$, $\mathrm{b}=10.583(1), \mathrm{c}=6.824(1) \AA$, with $\mathrm{V}=574.8(1) \AA^{3}, \mathrm{Z}=4$.

The chemical composition of bytízite (Table S12) corresponds very well with the formula $\mathrm{Cu}_{3} \mathrm{SbSe}_{3}$ derived from the crystal-structure study. Only weak Sb-As and S-Se substitution was observed; a similar trend was found in other $\mathrm{Cu}-\mathrm{Sb}$ selenides from Příbram: permingeatite [52] and přibramite [47]. The empirical formula, based on electron-microprobe analyses $(n=68)$, is $\left(\mathrm{Cu}_{3.00} \mathrm{Fe}_{0.01} \mathrm{Ag}_{0.01}\right)_{\Sigma 3.02}\left(\mathrm{Sb}_{0.97} \mathrm{As}_{0.06}\right)_{\Sigma 1.03}\left(\mathrm{Se}_{2.94} \mathrm{~S}_{0.01}\right)_{\Sigma 2.95}$.

\subsubsection{Cadmoselite, CdSe and Greenockite, CdS}

Cadmoselite is a very rare mineral identified in two polished sections prepared from one sample. In the first case, it forms anhedral to euhedral grains up to $10 \mu \mathrm{m}$ in size in later clausthalite (Figure 20); spheroidal aggregates of uraninite are also present. In the second case, cadmoselite is intergrown with Cd-hakite and clausthalite (Figure 21) as euhedral grains up to $40 \mu \mathrm{m}$ or as thin tabular crystals in the central part of $\mathrm{Cd}$-hakite aggregates. The euhedral forms of cadmoselite and cavities in the Cd-hakite indicate that cadmoselite is a later mineral replacing earlier Cd-hakite. 


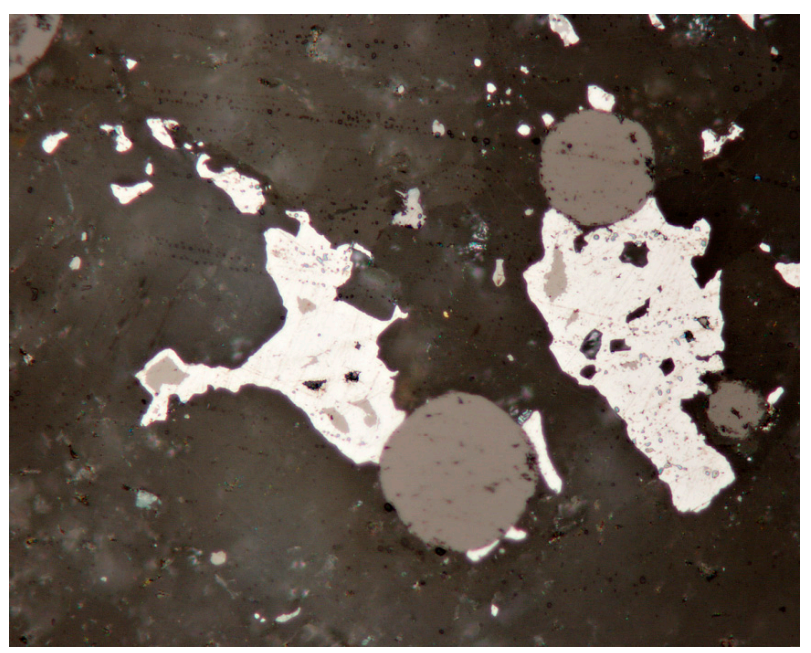

Figure 20. Brownish grey inclusions of cadmoselite in white clausthalite aggregates in association with grey spherical uraninite aggregates in calcite gangue. Reflected light, one polarizer. FOV $210 \mu \mathrm{m}$. Přibram, a dump of shaft 16. Photo by P. Škácha.

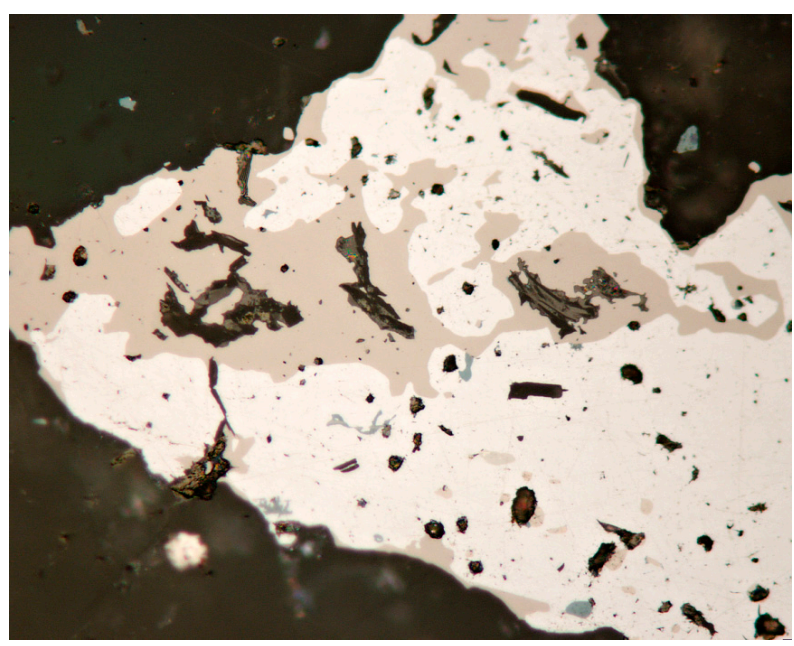

Figure 21. Dark grey euhedral crystals of cadmoselite in tiny cavities of a light brownish aggregate of Cd-hakite overgrowing by light clausthalite. Reflected light, one polarizer. FOV is $210 \mu \mathrm{m}$. Př́bram, a dump of the shaft 16. Photo by P. Škácha.

In reflected light, cadmoselite is dark grey and has a rather weak anisotropy.

The cation position in the studies of cadmoselite shows a minor substitution by $\mathrm{Hg}(0.01$ apfu $)$ and $\mathrm{Cu}$ (0.01-0.02 apfu) (Table S13). The minor contents of S in the anion position do not exceed $0.01 \mathrm{apfu}$. Its chemical composition is very similar to type samples from the Ust' Uyok deposit, Russia [84]. The empirical formula (average of four spot analyses based on 2 apfu) is $\left(\mathrm{Cd}_{0.99} \mathrm{Hg}_{0.01} \mathrm{Cu}_{0.01}\right)_{\Sigma 1.01}\left(\mathrm{Se}_{0.98} \mathrm{~S}_{0.01}\right)_{\Sigma 0.99}$. Cadmoselite from the Tumiñico deposit [79] contains $\mathrm{Hg}$ up to $0.05 \mathrm{apfu}$. The limited solid solution observed of $\mathrm{Hg}$ for $\mathrm{Cd}$ is consistent with the fact that cadmoselite and HgSe (tiemannite) have different crystal structures of, respectively, the wurtzite and sphalerite types. The diagram of $\mathrm{Hg}$ and $\mathrm{Cd}$ contents in cadmoselite, tiemannite, and greenockite are presented in Figure 22. 


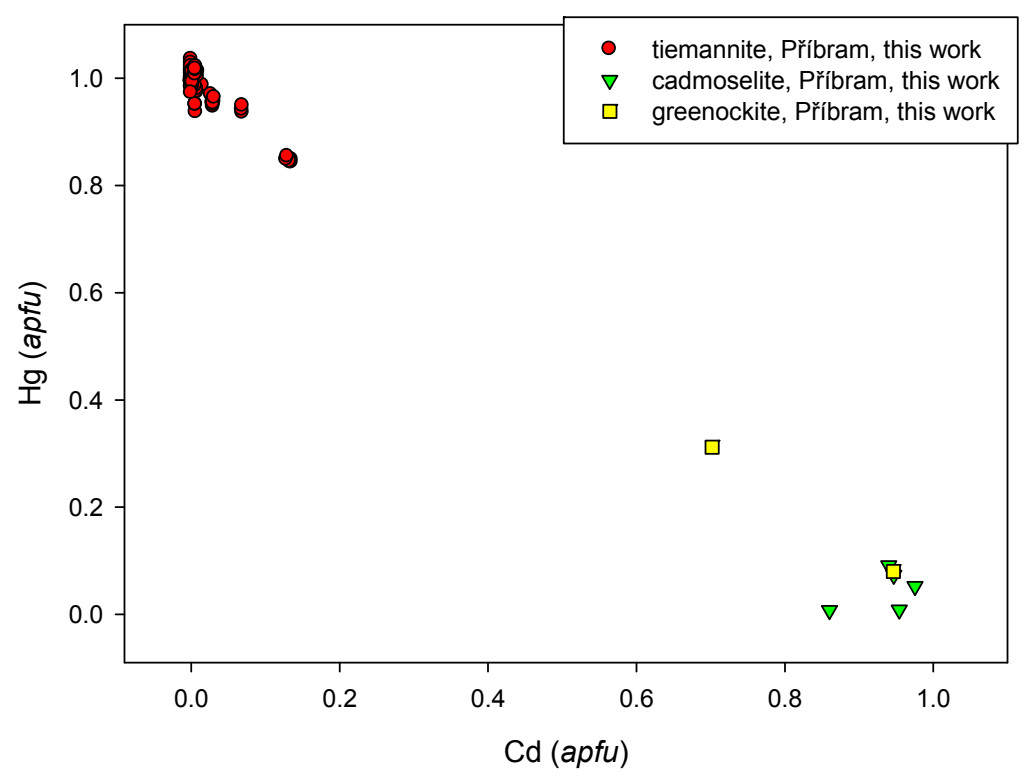

Figure 22. Cd vs. $\mathrm{Hg}(a p f u)$ graph for tiemannite, cadmoselite, and greenockite from Příbram.

Cadmoselite is a very rare mineral. In addition to the type locality-a vanadium-uranium-selenium deposit in Ust' Uyok, Siberia, Russia [84]—it is reported only from a single occurrence at the vein-type Tumiñico hydrothermal deposit by Paar et al. [79].

Greenockite occurs in the studied association as euhedral to subhedral grains up to $20 \times 8 \mu \mathrm{m}$ with euhedral chalcopyrite grains, cadmoselite, and uraninite. In reflected light, greenockite is grey and weakly anisotropic.

With regard to a minimal number of grains suitable for analysis, only two chemical analyses of greenockite were obtained; in addition to predominant $\mathrm{Cd}$ and $\mathrm{S}$, also $\mathrm{Hg}(0.08$ a $0.31 \mathrm{apfu})$ and minor $\mathrm{Zn}, \mathrm{Ag}$, and $\mathrm{Tl}$ were measured. The anion position shows a partial substitution SeS-1 with Se contents up to 0.06 apfu (Table S14). A diagram of $\mathrm{Hg}$ vs. Cd contents in cadmoselite, tiemannite, and greenockite are presented in Figure 22.

\subsubsection{Chaméanite, $(\mathrm{Cu}, \mathrm{Fe})_{4} \mathrm{As}(\mathrm{Se}, \mathrm{S})_{4}$}

Chaméanite is a very rare selenide known only at several localities worldwide (Chaméane [77], Tumiñico [79], and Předbořice [41]). At Prríbram, it was identified in a sample carrying $\mathrm{Tl}, \mathrm{Cu}, \mathrm{Fe}$, and $\mathrm{Sb}$ selenides. Chaméanite forms up to $0.7 \mathrm{~mm}$ long subhedral grains with a very strong cleavage, in association with eskebornite, hakite, tetrahedrite, closer unidentified $\mathrm{Tl}$ selenides, přibramite, and bytízite (Figure 23).

In reflected light, isotropic chaméanite is grey to grey-blue with various color shades depending on the $\mathrm{Cu} / \mathrm{Fe}$ ratio.

The average chemical composition of chaméanite from Prribram (Table S15) is close to the ideal formula $(\mathrm{Cu}, \mathrm{Fe})_{4} \mathrm{As}(\mathrm{Se}, \mathrm{S})_{4}$. The $\mathrm{Cu} / \mathrm{Fe}$ ratio $(a p f u)$ is extremely variable between 4 and 356 , due to the very low local Fe content (Figure 24). For the original Chaméane material, the $\mathrm{Cu} / \mathrm{Fe}$ ratio is in the range of 6-13 [77], and from the Tumiñico locality, it is 15 [79]. The chaméanite from Př́bram also contains minor Ag (0.01-0.13 apfu), Sb (0.00-0.28 apfu), $\mathrm{Tl}$ (up to $0.06 \mathrm{apfu}), \mathrm{Hg}$ (up to $0.05 \mathrm{apfu}$ ), and S (up to $0.08 \mathrm{apfu}$ ). The empirical formula of Přibram chaméanite (average of 100 analyses)—based on 9 apfu—is $\left(\mathrm{Cu}_{3.63} \mathrm{Fe}_{0.33} \mathrm{Ag}_{0.03}\right)_{\Sigma 3.99}\left(\mathrm{As}_{0.88} \mathrm{Sb}_{0.08}\right)_{\Sigma 0.96}\left(\mathrm{Se}_{4.03} \mathrm{~S}_{0.02}\right)_{\Sigma 4.05}$. 


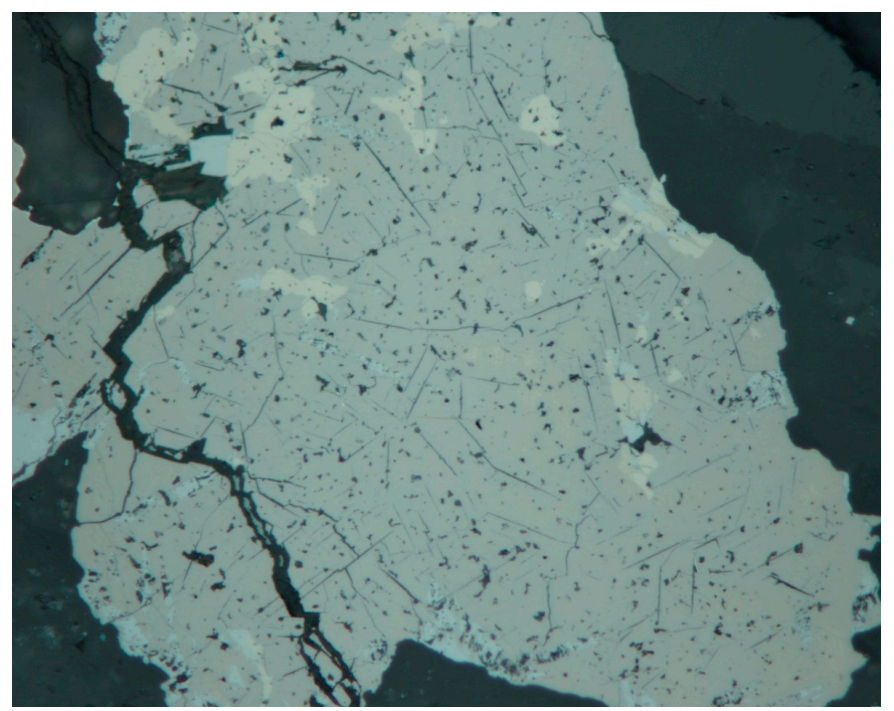

Figure 23. Brown chaméanite aggregate with grey giraudite and light brown eskebornite inclusions in the association. Reflected light, one polarizer. FOV $210 \mu \mathrm{m}$. Přibram, a dump of shaft 16. Photo by P. Škácha.

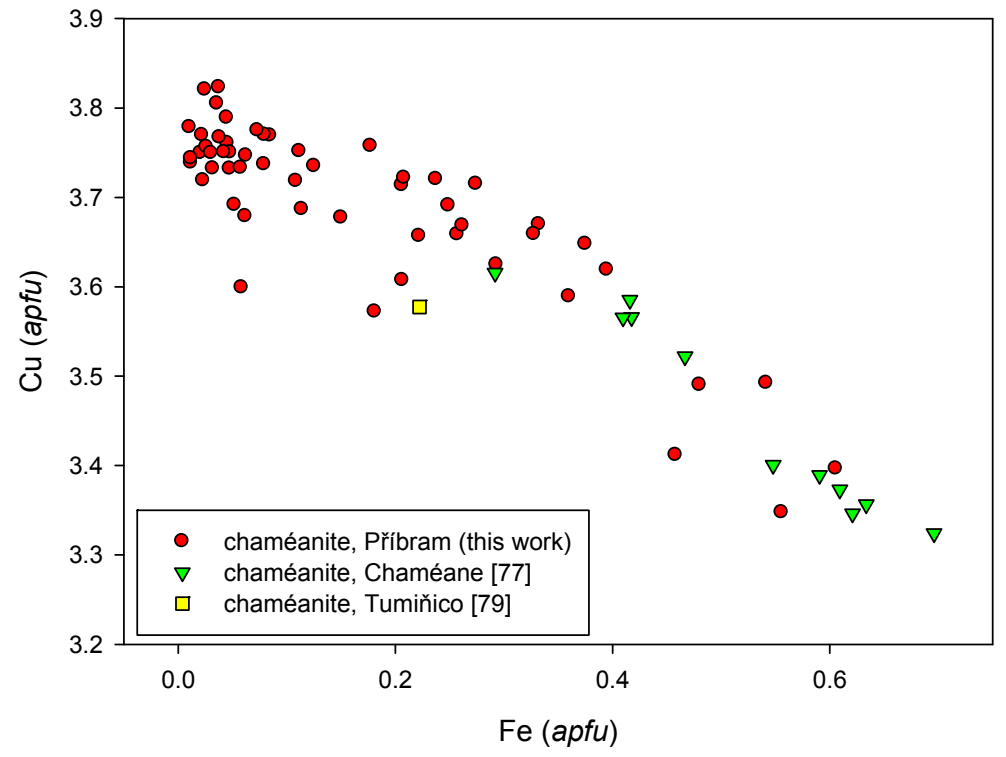

Figure 24. Fe vs. Cu (apfu) graph for chaméanite from Příbram and other localities.

\subsubsection{Clausthalite, PbSe}

Clausthalite is the most abundant selenide observed at the deposit. It was described by Růžička [48] from the Bt4 vein and by Litochleb et al. [49] in a sample from Bytíz. Later on, clausthalite was found locally abundant in material from shafts 16 and 11A [50,51].

Clausthalite was observed in numerous mineral associations. At first, it was described with arsenic and arsenolamprite as irregular grains tens of $\mu \mathrm{m}$ long, in irregular intergrowth with arsenic [50]. Later on, its occurrence with cuprostibite was described Škácha et al. [51] as silvery-grey fine-grained and irregular aggregates up to $2 \mathrm{~mm}$ in dark calcite. In this mode of occurrence, it is soft, without distinct cleavage. It is white in reflected light, and it overgrows and replaces mainly an older chalcocite.

Clausthalite occurs at the deposit as fine-grained aggregates without visible cleavage, as well as perfectly cleavable aggregates up to $0.5 \mathrm{~cm}$ across in close association with botryoidal uraninite. It differs from megascopically-similar galena by the absence of associated sphalerite. Clausthalite is 
intergrown with the majority of other selenides and sulphides (Figure 25). It forms euhedral crystals up to $50 \mu \mathrm{m}$ in size, rarely in association with inhomogeneous $\mathrm{Cu}-\mathrm{Sb}$ oxycompound(s), eucairite, and other minerals (Figure 26). Like tiemannite, clausthalite belongs among the earlier selenides, but both minerals occur together only rarely. In that case, clausthalite grains were observed in tiemannite aggregates; thus, clausthalite is probably earlier than tiemannite. It is probable that clausthalite occurs at the locality in more than a single generation.

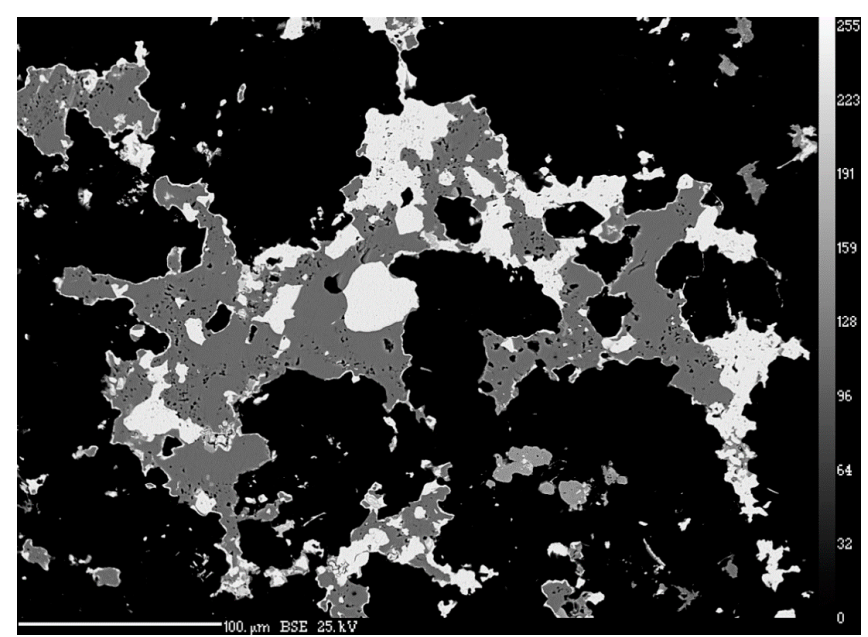

Figure 25. Light clausthalite in form of inclusions in dark chalcopyrite. BSE photo. Př́bram, a dump of shaft 16. Photo by J. Sejkora and P. Škácha.

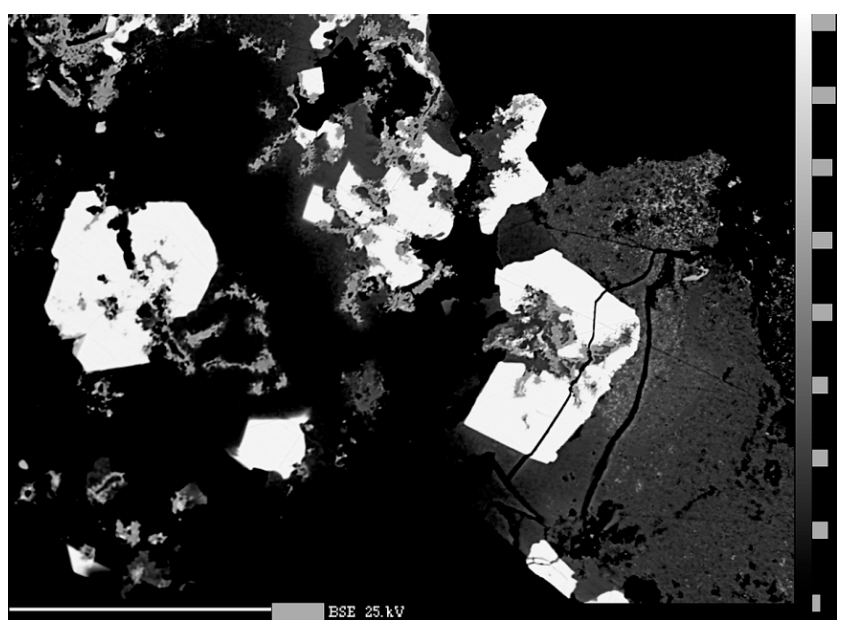

Figure 26. Euhedral clausthalite grains (white) in non-homogenous Cu-Sb oxide (dark grey). BSE photo. Přibram, a dump of shaft 16. Photo by J. Sejkora and P. Škácha.

In reflected light, clausthalite is white and isotropic.

We have observed only low contents of $\mathrm{Ag}, \mathrm{Tl}, \mathrm{Zn}, \mathrm{Sb}, \mathrm{As}$, and Te, not exceeding 0.05 apfu during the study of the chemical composition of clausthalite (Table S16). Somewhat higher are minor $\mathrm{Cu}$ contents up to $0.12 \mathrm{apfu}$. The $\mathrm{SeS}_{-1}$ substitution is limited in most cases; $\mathrm{S}$ contents up to 0.32 apfu were observed only sporadically. The limited range of $\mathrm{SeS}_{-1}$ substitution makes the Přibram clausthalite distinctly different from members of the clausthalite-galena series from localities of the West Bohemian ore district [85], Niederschlema-Alberoda [18], Běstvina [25], or Moldava localities [26]. The empirical formula of the studied Přibram clausthalite (average of 58 analyses) based on 2 apfu is $\left(\mathrm{Pb}_{0.98} \mathrm{Cu}_{0.02}\right)_{\Sigma 1.00}\left(\mathrm{Se}_{0.97} \mathrm{~S}_{0.01}\right)_{\Sigma 0.98}$. 


\subsubsection{Crookesite, $\mathrm{Cu}_{7}(\mathrm{Tl}, \mathrm{Ag}) \mathrm{Se}_{4}$}

Crookesite has been found in only one case, as several irregular inclusions up to $10 \mu \mathrm{m}$. It is closely associated with berzelianite and an unnamed $\mathrm{Cu}$-As selenide (Figure 27) in the specimen with bytízite and chaméanite.

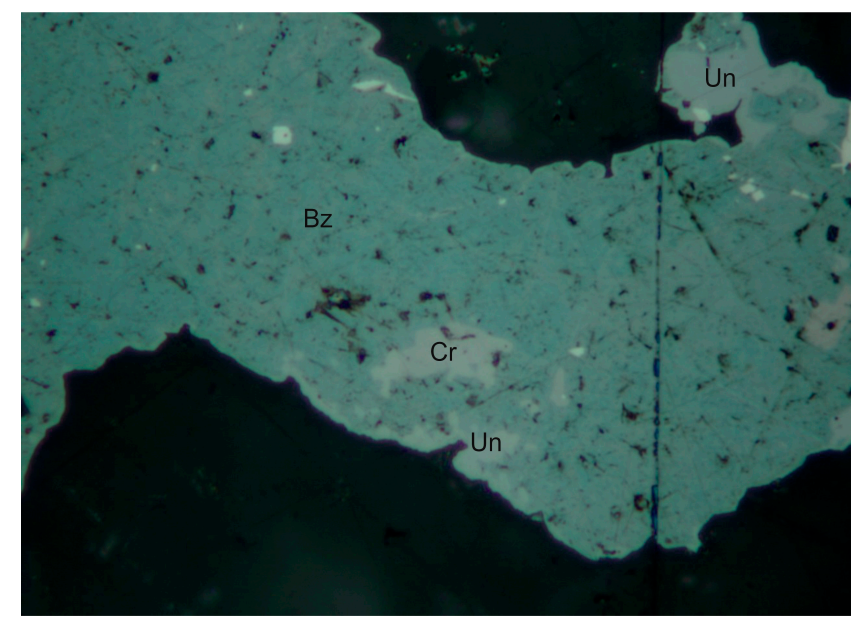

Figure 27. Anhedral brownish grey crookesite $(\mathrm{Cr})$ grain embedded in berzelianite $(\mathrm{Bz})$ in association with unnamed $\mathrm{Cu}-$ As selenide (Un). Reflected light, one polarizer. FOV $105 \mu \mathrm{m}$. Přibram, a dump of shaft 16. Photo by P. Škácha.

In reflected light, it is brownish grey and is weakly anisotropic.

The chemical composition of crookesite from Přibram (Table S17) is close to the ideal formula $\mathrm{Cu}_{7}(\mathrm{Tl}, \mathrm{Ag}) \mathrm{Se}_{4}$; it contains only minor amounts of $\mathrm{S}(0.02 \mathrm{apfu})$ and $\mathrm{Ag}(0.01 \mathrm{apfu})$. Its empirical formula (mean of two analyses) based on $12 \mathrm{apfu}$ can be expressed as $\mathrm{Cu}_{7.12}\left(\mathrm{Tl}_{0.93} \mathrm{Ag}_{0.01}\right)_{\Sigma 0.94}\left(\mathrm{Se}_{3.92} \mathrm{~S}_{0.02}\right)_{\Sigma 3.94}$.

\subsubsection{Dzharkenite-Pyrite Solid Solution, $\mathrm{FeSe}_{2}-\mathrm{FeS}_{2}$}

Dzharkenite is a selenium analogue of pyrite that occurs as a rare product of the youngest stage of mineralization. It forms anhedral to subhedral grains up to $60 \mu \mathrm{m}$ across in association with ferroselite and minerals of the tetrahedrite group antimonselite and přibramite (Figure 28).

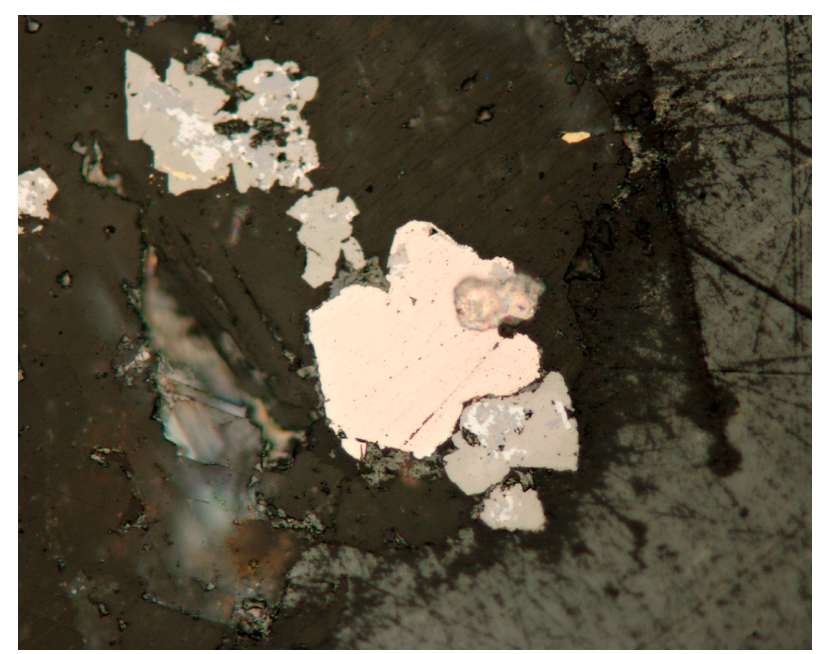

Figure 28. Pinkish subhedral dzharkenite grain in association with dark grey tetrahedrite enclosed light grey tiemannite inclusions. Reflected light, one polarizer. FOV $210 \mu \mathrm{m}$. Příbram, a dump of shaft 16. Photo by P. Škácha. 
In reflected light, dzharkenite is pink and isotropic. This makes it different from ferroselite, which is distinctly anisotropic in grey or brass yellow colors. Identification of dzharkenite and ferroselite was confirmed by EBSD (Figure 29).
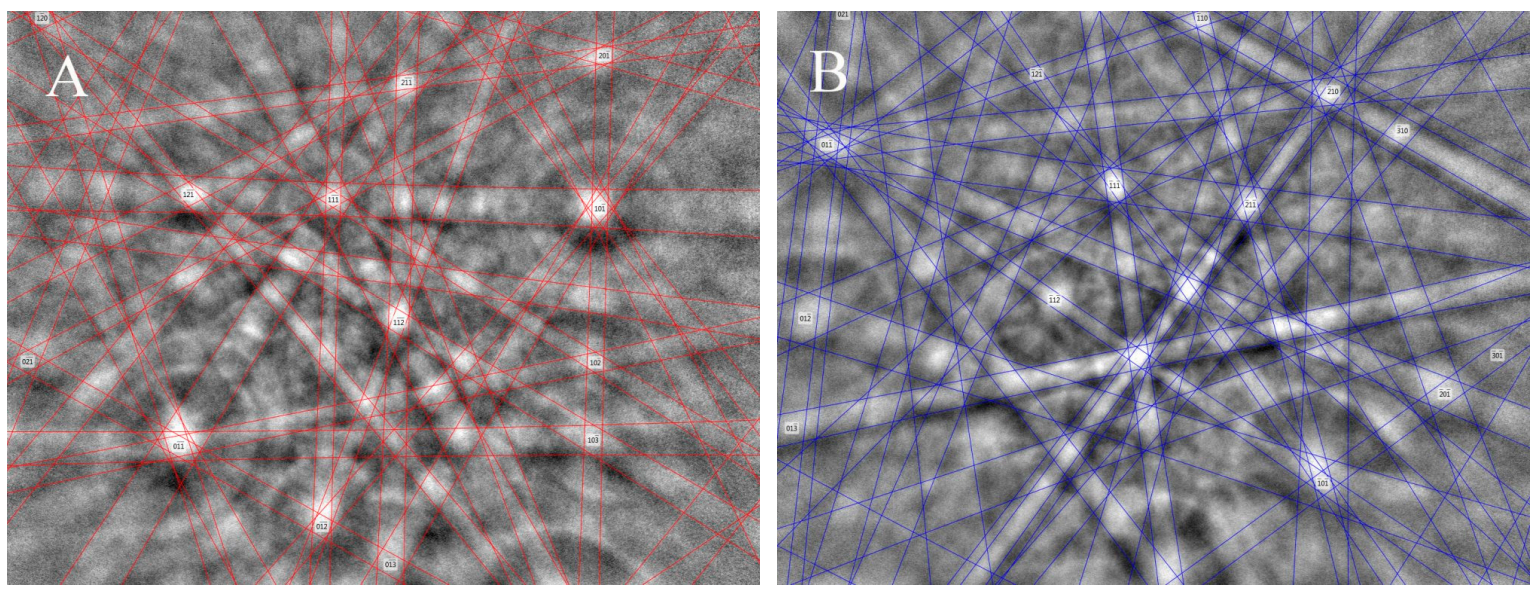

Figure 29. Electron backscatter diffraction (EBSD) images of (A) dzharkenite and (B) ferroselite (right) from Př́bram, with indexed Kikuchi bands. Photo by M. Racek.

The chemical composition of dzharkenite from Přibram is close to the ideal formula FeSe 2 . Copper content is 0.07 apfu at maximum and $S$ in the range 0.01-0.18 apfu (Table S18). Its empirical formula (average of 22 analyses) based on 3 apfu is $\left(\mathrm{Fe}_{0.98} \mathrm{Cu}_{0.02}\right)_{\Sigma 1.00}\left(\mathrm{Se}_{1.92} \mathrm{~S}_{0.08}\right)_{\Sigma 2.00}$.

Dzharkenite is a very rare mineral on a global scale. Ferroselite is the selenium analogue of marcasite, and is more common at hydrothermal uranium deposits $[4,7,86]$. Dzharkenite was first described from the Suluchekinskoye Se-U deposit in Kazakhstan by Yashunsky et al. [87]. Another occurrence was reported from the Zapadno-Ozernoe deposit of $\mathrm{Cu}-\mathrm{Zn}$ massive sulphides in Russia [88]; members of the solid solution pyrite-dzharkenite are here of a supergene origin. Dzharkenite occurs as minute octahedra enclosed in calcite at the Cisco locality, Utah [89]. Litochleb et al. [49] reported Se-rich pyrite (0.21-0.29 apfu Se) from the Bytíz deposit as minute subhedral grains up to $40 \times 80 \mu \mathrm{m}$ enclosed in calcite and partly rimmed by coffinite. A comparison of variation in Se and $S$ in the dzharkenite-pyrite solid solution from various occurrences is presented in Figure 30.

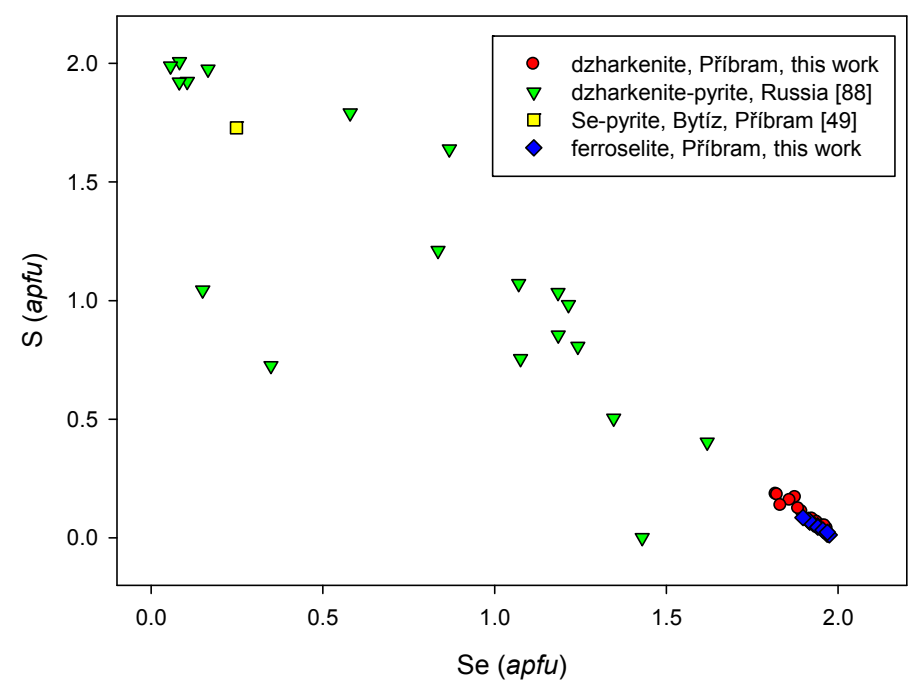

Figure 30. Se vs. S (apfu) graph of dzharkenite, ferroselite, and Se-pyrite from various localities. 


\subsubsection{Eskebornite-Chalcopyrite Solid Solution, $\mathrm{CuFeSe}_{2}-\mathrm{CuFeS}_{2}$}

Minerals of the eskebornite-chalcopyrite isomorphic series are relatively common at the deposit. Eskebornite occurs only locally, but chalcopyrite is known from many places.

Eskebornite was observed as anhedral brown $1 \mathrm{~mm}$ grains in association with $\mathrm{Cu}$-selenides and hakite. It also forms aggregates with abundant umangite and berzelianite grains (Figure 31) or inclusions in hakite aggregates (Figure 32). Eskebornite also replaces earlier uraninite spherical aggregates (Figure 33).

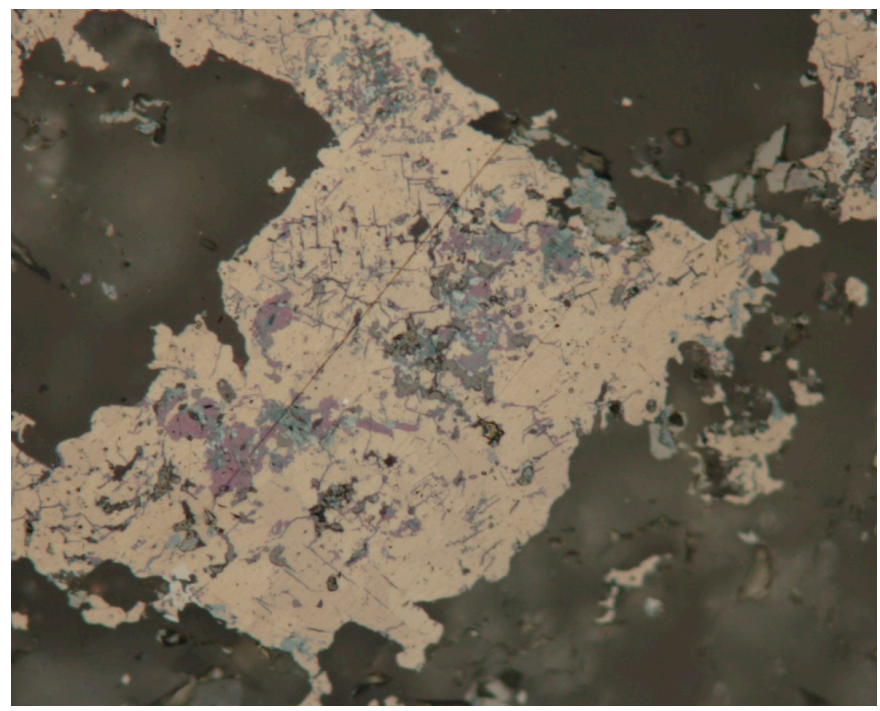

Figure 31. Brown eskebornite with inclusions of violet umangite, blue berzelianite, and dark grey uraninite. Middle grey minor tetrahedrite is in the association. Reflected light, one polarizer. FOV is $210 \mu \mathrm{m}$. Př́bram, dump at shaft 16. Photo by P. Škácha.

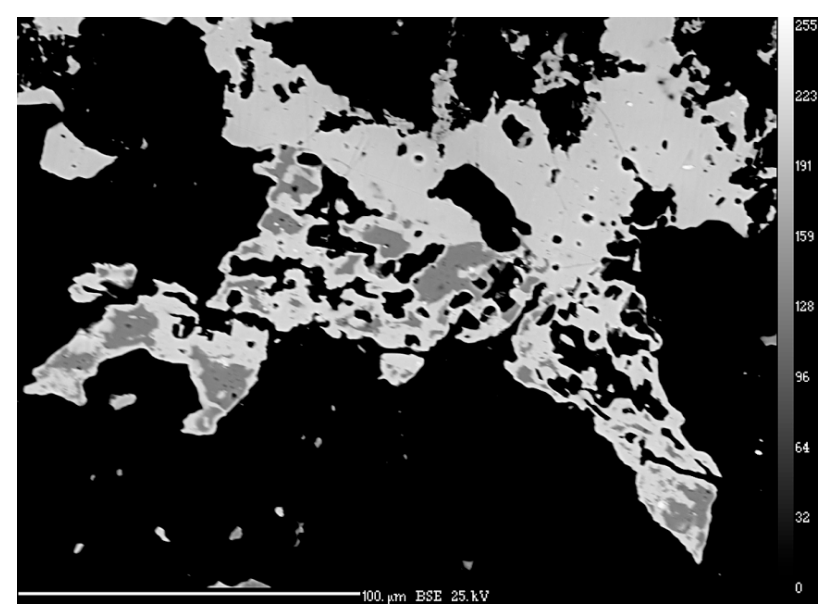

Figure 32. Eskebornite grains (dark grey) in hakite aggregates (light grey). BSE photograph. Př́bram, a dump of shaft 16 . Photo by J. Sejkora, P. Škácha.

In reflected light, eskebornite is light brown with a pink shade. It is strongly anisotropic under crossed polarizers.

In the course of the study of the chemical composition of eskebornite (Table S19), aside from minor contents of $\mathrm{Te}, \mathrm{Ag}$, and $\mathrm{Tl}$, two groups of analyses with different $\mathrm{S}$ contents were observed: 0-0.17 apfu and 0.57-0.79 apfu S. The empirical formulae for these eskebornite types from Příbram are the following: 
$\mathrm{Cu}_{1.03} \mathrm{Fe}_{0.99}\left(\mathrm{Se}_{1.92} \mathrm{~S}_{0.05}\right)_{\Sigma 1.97}$ (S-poor, the mean of 19 analyses) and $\mathrm{Cu}_{1.06} \mathrm{Fe}_{0.95}\left(\mathrm{Se}_{1.31} \mathrm{~S}_{0.66}\right)_{\Sigma 1.97}$ (S-rich, the mean of seven analyses).

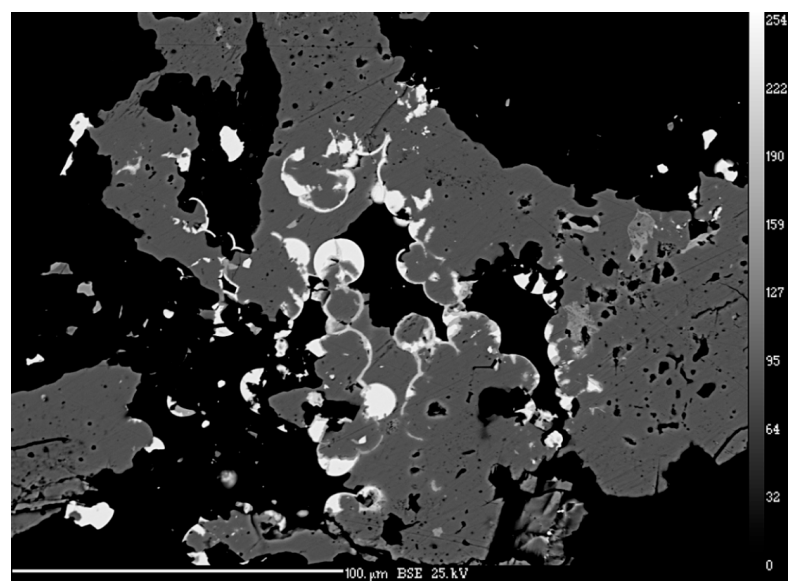

Figure 33. Eskebornite aggregates (dark grey) partly replace earlier spherical aggregates of uraninite (white). BSE photograph. Př́bram, a dump of shaft 16. Photo by J. Sejkora, P. Škácha.

Eskebornite is a relatively abundant selenide in hydrothermal uranium deposits. In the Czech Republic, it was reported from Slavkovice [90], Habří [91], and Petrovice deposits [92].

Chalcopyrite is one of the most common sulphides present in the carbonate-uraninite stage, in association with tetrahedrite, uraninite, and selenides. It forms typical golden yellow elongated aggregates up to several centimeters long. Chalcopyrite in the aggregates is mainly anhedral with some grains tending towards euhedral. A study of polished sections shows that chalcopyrite is later than tetrahedrite, and belongs to the youngest minerals of the whole mineral association (Figure 32).

In reflected light, it is strongly yellow and weakly anisotropic.

During the study of the chemical composition of chalcopyrite, only local minor contents of $\mathrm{Ag}$, $\mathrm{Pb}, \mathrm{Tl}$, and $\mathrm{Sb}$ were observed (Table $\mathrm{S} 20$ ). The $\mathrm{SeS}_{-1}$ substitution is more significant, but the Se content still never exceeds 0.21 apfu. Figure 34 shows the $S$ and Se contents of chalcopyrite-eskebornite solid solutions from various localities, and suggests the presence of a possible solvus gap.

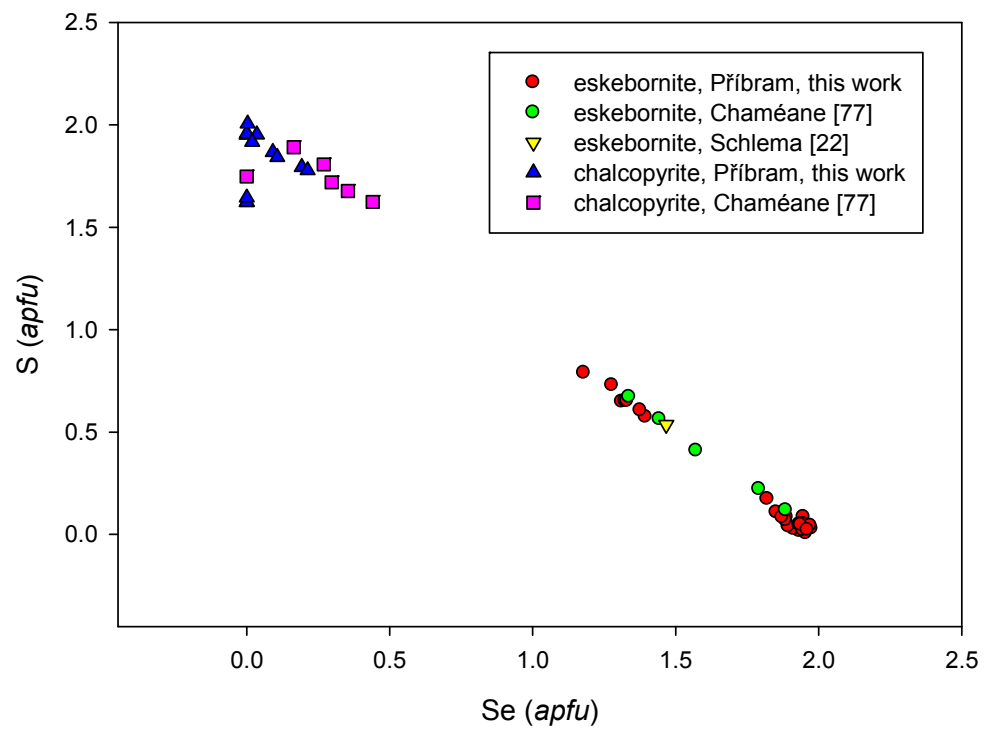

Figure 34. Se vs. S (apfu) graph of chalcopyrite and eskebornite from various localities. 


\subsubsection{Eucairite, AgCuSe}

Eucairite in studied samples forms abundant anhedral aggregates up to $0.5 \mathrm{~mm}$, which most frequently occur in association with berzelianite and umangite (Figure 35). It is earlier than $\mathrm{Cu}$-selenides, which replace eucairite (Figure 36). The eucairite inclusions in clausthalite were observed only rarely.

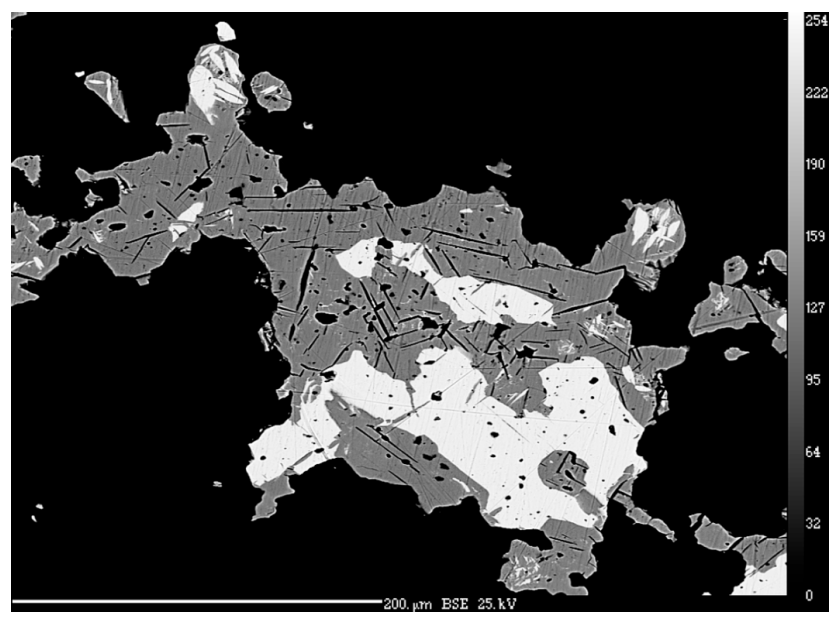

Figure 35. Umangite (dark grey) aggregates partly replace earlier eucairite (light grey). BSE photograph. Přibram, a dump of shaft 16 . Photo by J. Sejkora and P. Škácha.

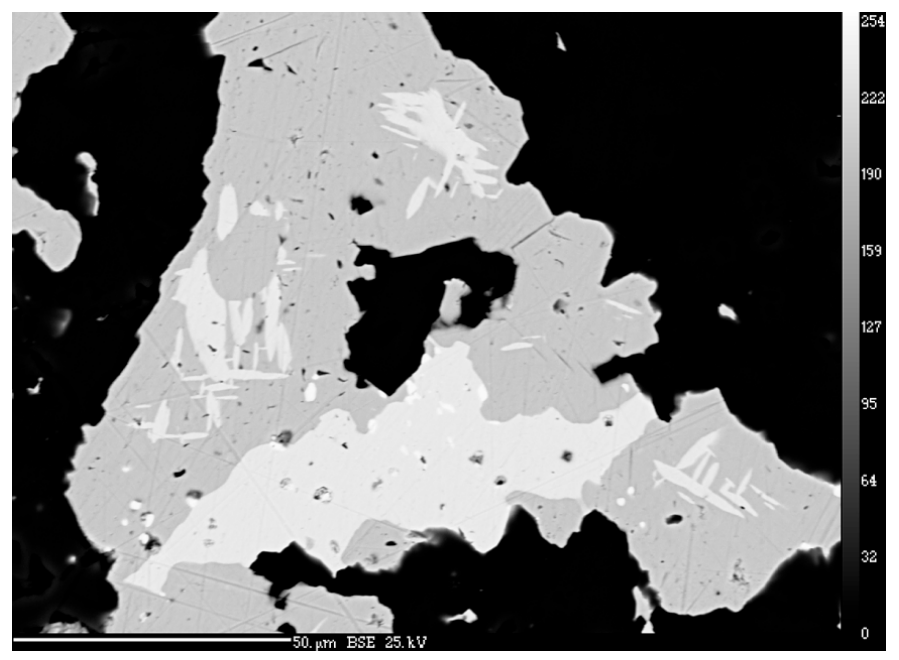

Figure 36. Berzelianite (grey) replaces earlier eucairite aggregates (white). BSE photograph. Př́bram, a dump of shaft 16. Photo by J. Sejkora and P. Škácha.

In reflected light, it has a cream-yellow color with a pink shade. It is strongly anisotropic from blue-green to blue-grey colors.

The X-ray powder diffraction data of eucairite from Příbram (Table S21) agree very well with data calculated from the crystal structure information [93]. The refined unit-cell parameters of eucairite from Přibram are compared with the published data in Table S22.

During the chemical study of eucairite from Přibram, minor contents of $\mathrm{Tl}$, As, and Te in addition to the dominant elements (Table S23) were determined. The empirical formula of eucairite from Přibram (the average of 48 analyses) based on 3 apfu is $\mathrm{Ag}_{1.00} \mathrm{Cu}_{1.04}\left(\mathrm{Se}_{0.95} \mathrm{Te}_{0.01}\right)_{\Sigma 0.96}$.

An interesting phase related to eucairite was observed in a single polished section. It forms rather inhomogeneous aggregates up to $200 \mu \mathrm{m}$, with penetrating naumannite lamellae. Both of the minerals 
probably represent products of disintegration of an unknown Ag-Cu-Se mineral that is stable at higher temperatures. This mineral (after recalculation to $3 \mathrm{apfu}$ ) shows a strong variation in contents of $\mathrm{Ag}$ (1.18-1.63 apfu), Cu (0.31-0.63 apfu), and Se (1.05-1.18 apfu). Minor Hg contents (to $0.01 a p f u)$, Te (to $0.003 \mathrm{apfu}$ ), and S (to $0.01 \mathrm{apfu}$ ) were also observed in this mineral phase (Table S24).

\subsubsection{Ferroselite, $\mathrm{FeSe}_{2}$}

Ferroselite occurs only rarely in studied samples. It forms idiomorph crystals up to $15 \mu \mathrm{m}$ (Figure 37) and their aggregates not exceeding $50 \mu \mathrm{m}$ in calcite gangue. Dzharkenite, přibramite, antimonselite, and a new $\mathrm{Hg}$-Cu-Sb-selenide were found in association.

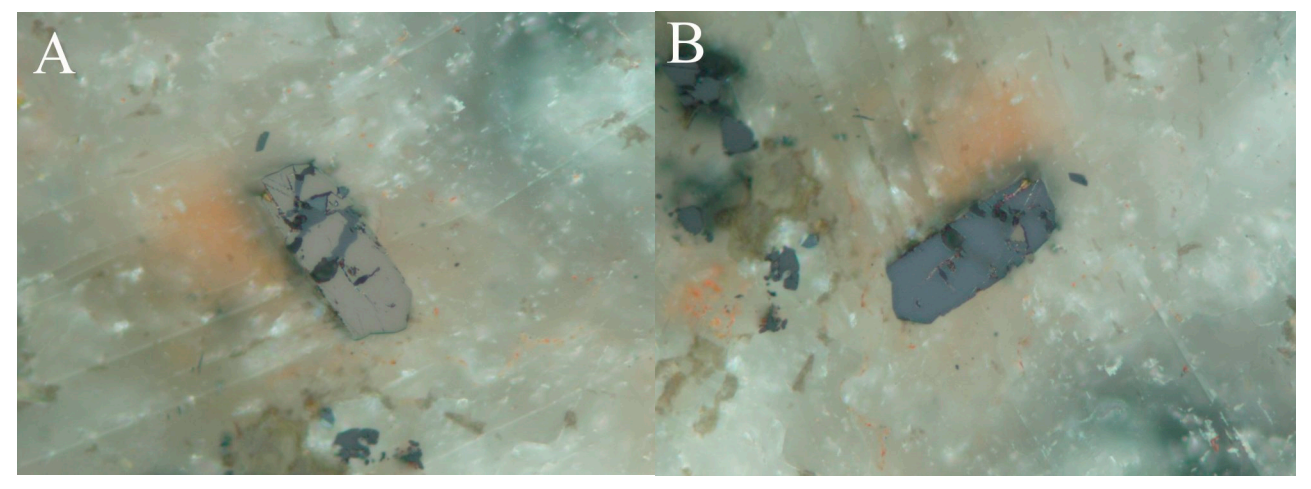

Figure 37. Pinkish ferroselite anhedral grain with very intensive anisotropism (A,B). Reflected light, partly-crossed polarizers. FOV $210 \mu \mathrm{m}$. Příbram, a dump of shaft 16. Photo by P. Škácha.

In reflected light, it has a cream-yellow color with a pink shade. It is strongly anisotropic from blue-green to blue-grey. Identification of ferroselite and dzharkenite was confirmed by EBSD (Figure 29).

The chemical composition of ferroselite does not significantly differ from dzharkenite, and is close to the ideal formula $\mathrm{FeSe}_{2}$. Copper contents up to 0.02 apfu and S contents in the range 0.01-0.09 apfu were determined (Table S25). The empirical formula of ferroselite from Př́bram (the mean of 12 analyses) based on 3 apfu is $\left(\mathrm{Fe}_{1.00} \mathrm{Cu}_{0.01}\right)_{\Sigma 1.01}\left(\mathrm{Se}_{1.94} \mathrm{~S}_{0.05}\right)_{\Sigma 1.99}$.

\subsubsection{Klockmannite, CuSe}

Klockmannite is very rare in the studied material. It was observed in several samples as anhedral grains up to $30 \mu \mathrm{m}$ across composed of very thin lamellar crystals intergrown with berzelianite in association with uraninite and tiemannite (Figure 38).

It is blue in reflected light, is anisotropic, and it shows a strong bireflection.

During the study of the chemical composition of klockmannite from Příbram (Table S26), increased Ag contents (up to 0.03 apfu) were observed; the cation/anion ratio varies in the range 0.90-1.05, probably due to intergrowth with other $\mathrm{Cu}$-selenides on a sub-microscopic scale. In the anion site, dominant Se is substituted by $\mathrm{Te}$ and $\mathrm{S}$ in a minor range. The empirical formula of klockmannite (average of nine analyses) on the basis of 2 apfu is $\left(\mathrm{Cu}_{0.98} \mathrm{Ag}_{0.02}\right)_{\Sigma 1.00}\left(\mathrm{Se}_{0.98} \mathrm{~S}_{0.03}\right)_{\Sigma 1.01}$. Variation of Se vs. $\mathrm{S}$ in klockmannite from several localities in the Czech Republic is presented in Figure 39. 


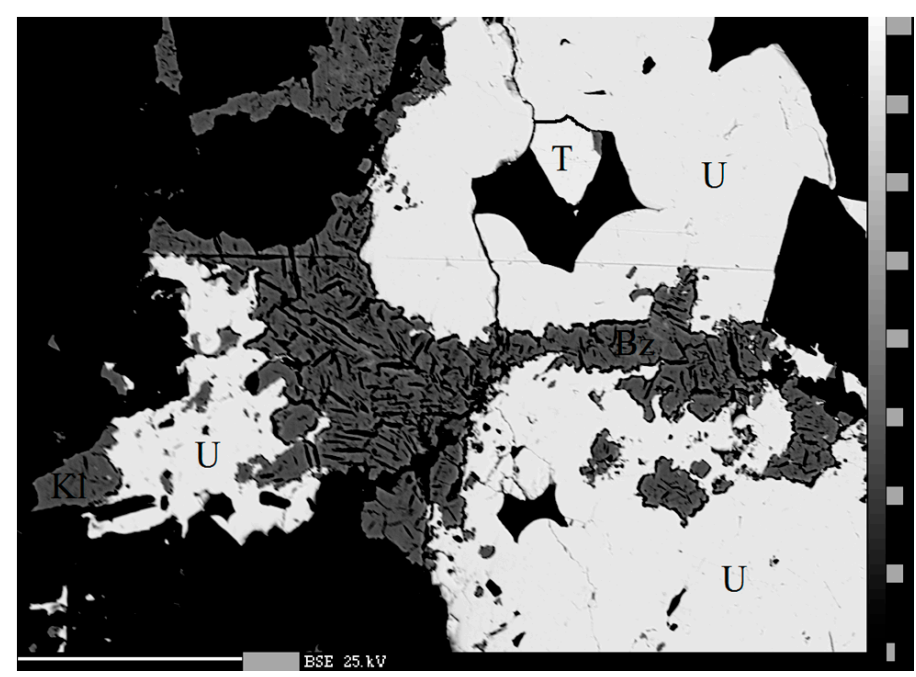

Figure 38. A euhedral tiemannite crystal $(\mathrm{T})$ occurs in the cavity of uraninite aggregates (U), in the association are Cu-selenides (dark grey) including klockmannite (K1) and berzelianite (Bz). BSE photograph. Př́bram, a dump of shaft 16. Photo by J. Sejkora and P. Škácha.

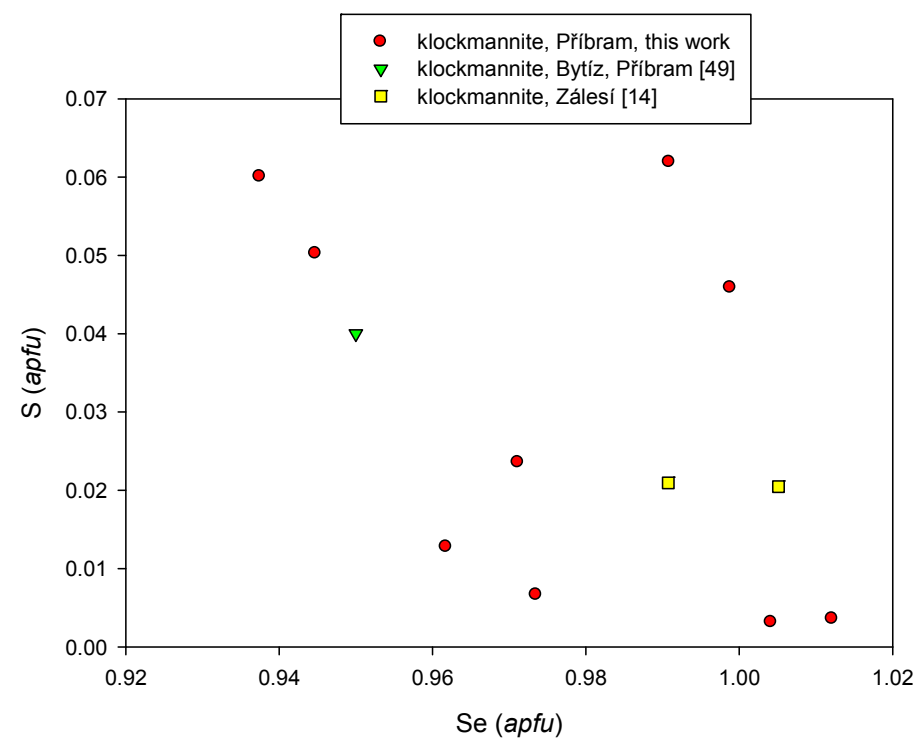

Figure 39. Se vs. S (apfu) graph for klockmannite.

In the sample from Přibram described by Litochleb et al. [49], klockmannite is the predominant phase in compound grains and aggregates. The size of anhedral grains is up to $70 \times 150 \mu \mathrm{m}$, and rarely $1 \mathrm{~mm}$. In places, the aggregates enclose minute pieces of earlier umangite and athabascaite. The observed sulphur contents are up to 0.7 apfu [49].

\subsubsection{Naumannite, $\mathrm{Ag}_{2} \mathrm{Se}$}

Naumannite was only observed in a limited number of polished sections; however, it was relatively abundant in some cases. It forms anhedral grains up to $40 \mu \mathrm{m}$ in association with tiemannite and inhomogenous aggregates of AgCuSe minerals (Figures 40 and 41). 


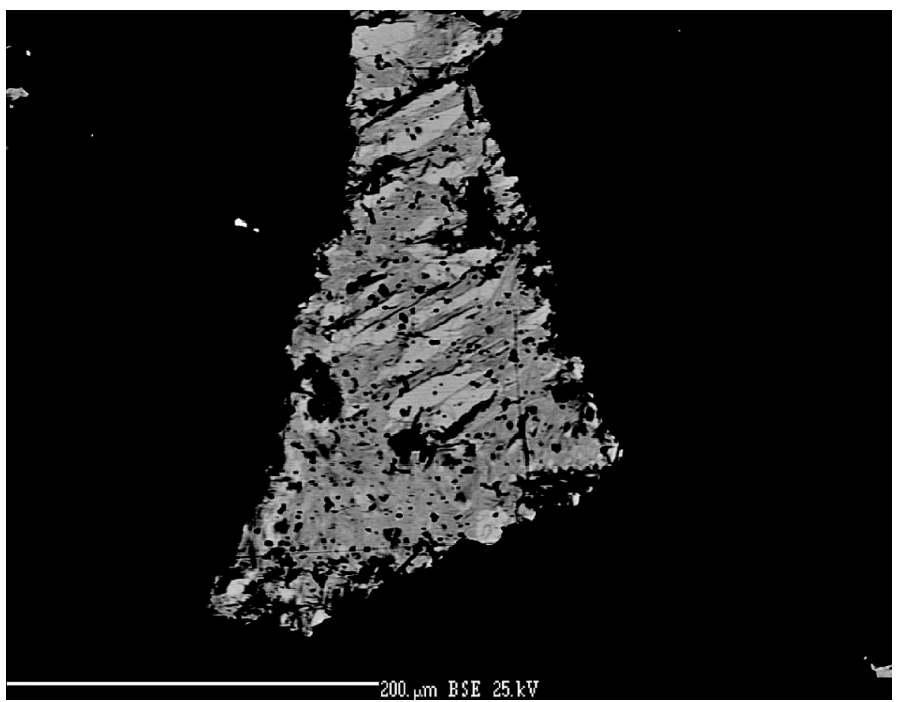

Figure 40. Inhomogeneous aggregates of $\mathrm{Ag}-\mathrm{Cu}-\mathrm{Se}$ phase close to eucairite with naumannite lamellae (light grey). BSE photograph. Příbram, a dump of shaft 16. Photo by J. Sejkora and P. Škácha.

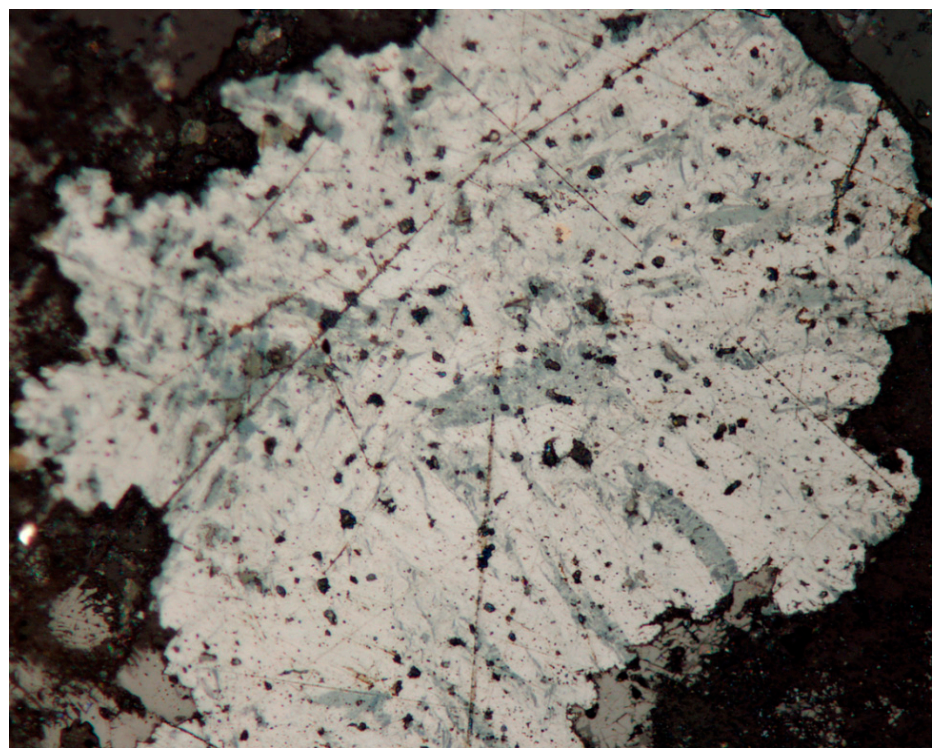

Figure 41. Pinkish inhomogeneous aggregates of Ag-Cu-Se phase close to eucairite with naumannite lamellae and greyish blue Cu-selenide. Reflected light, one polarizer. The width of the area is $210 \mu \mathrm{m}$. Př́bram, a dump of shaft 16. Photo by P. Škácha.

In reflected light, naumannite is grey and weakly anisotropic.

The chemical composition of naumannite from Přibram is usually relatively simple; minor contents of $\mathrm{Cd}, \mathrm{Hg}$, As, and $\mathrm{Te}$ (Table S27) were observed locally. Naumannite aggregates with increased $\mathrm{Cu}$ contents up to 0.36 apfu were observed in rare cases (Figure 42). The empirical formula of naumannite (from the mean of 30 analyses) calculated on the basis of 3 apfu is $\left(\mathrm{Ag}_{1.96} \mathrm{Cu}_{0.06}\right)_{\Sigma 2.02} \mathrm{Se}_{0.97}$. 


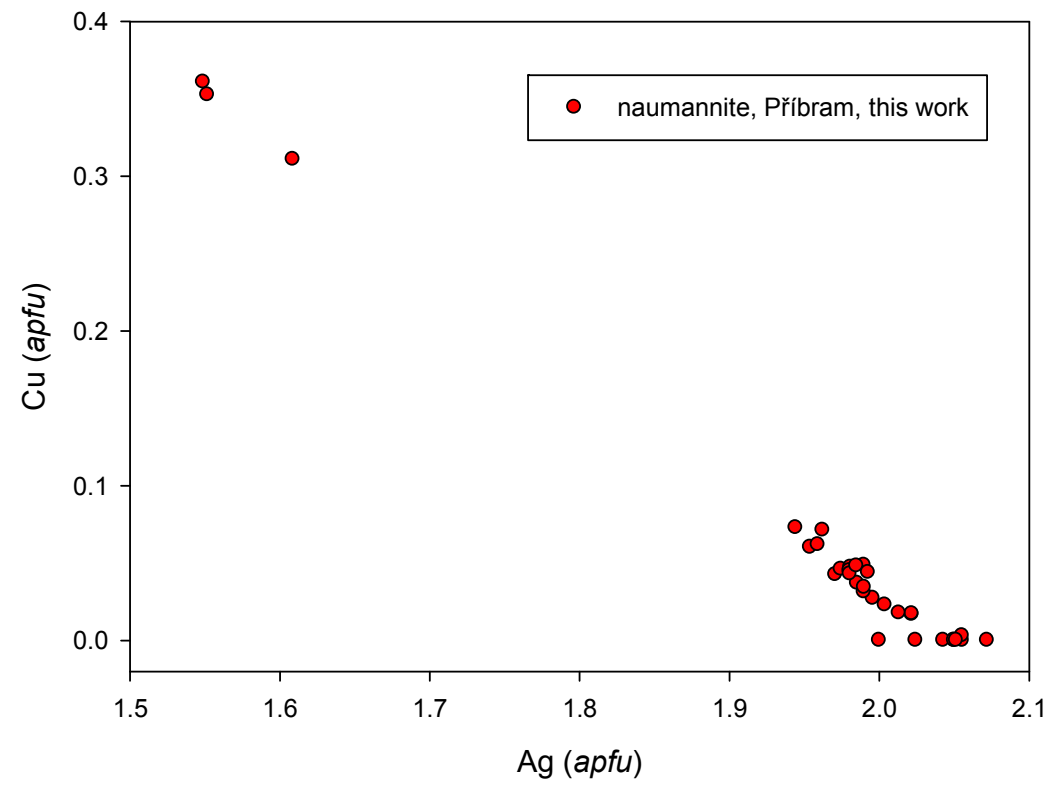

Figure 42. Ag vs. $\mathrm{Cu}(a p f u)$ graph for naumannite.

\subsubsection{Permingeatite, $\mathrm{Cu}_{3} \mathrm{SbSe}_{4}$}

The occurrence of permingeatite in the studied material was described in detail by Škácha et al. [52]. The mineral occurs as anhedral grains and aggregates, in the rare case up to $1 \mathrm{~mm}$ across in brownish or black calcite, in association with chalcopyrite, hematite, príbramite, antimonselite, dzharkenite, ferroselite, uraninite, löllingite, clausthalite, hakite, berzelianite, umangite, and eskebornite. A narrow clausthalite rim was developed around some permingeatite aggregates (Figure 43). In the studied assemblage, uraninite is locally abundant as typical colloform aggregates with a strong semi-metallic lustre. Permingeatite grains show megascopic bronze-brown color with a yellow shade and a strong metallic lustre. Permingeatite is brownish pink in reflected light and its anisotropy is strong. In comparison with the data of Johan et al. [40] for material from Předbořice, the measured reflectance values for permingeatite from Přibram [52] are different, probably due to the use of different standards.

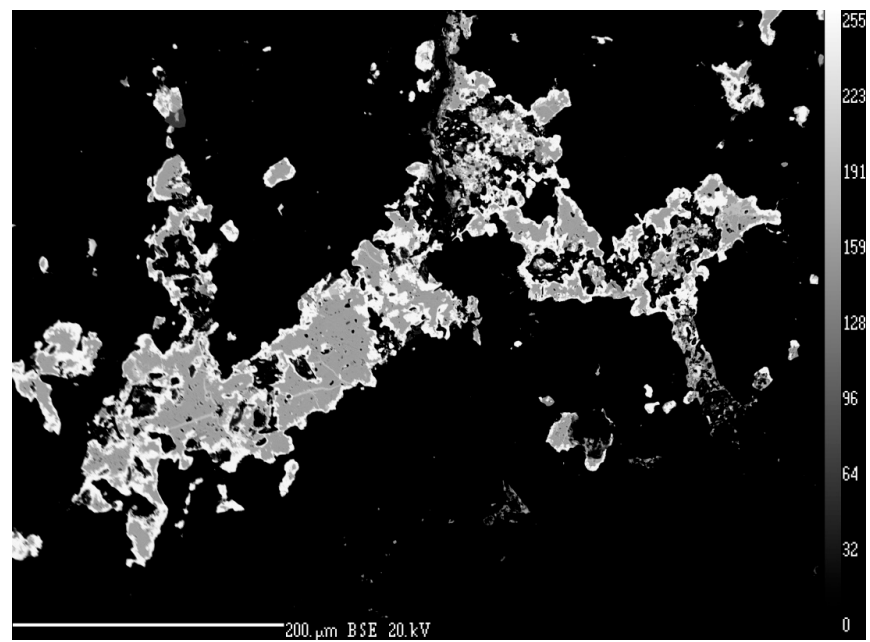

Figure 43. Permingeatite anhedral grains (grey) rimmed by clausthalite (white). BSE photograph. Přibram, a dump of shaft 16. Photo by J. Sejkora and P. Škácha. 
WDS data for permingeatite published by Škácha et al. [52] indicate a partial Se-S substitution corresponding to the solid solution of permingeatite $\left(\mathrm{Cu}_{3} \mathrm{SbSe}_{4}\right)$-famatinite $\left(\mathrm{Cu}_{3} \mathrm{SbS}_{4}\right)$. In addition to contents of $\mathrm{Cu}, \mathrm{Sb}, \mathrm{Se}$, and $\mathrm{S}$, only minor Fe contents were documented, which imperfectly correlate with $\mathrm{Cu}$. The empirical formula of the studied S-rich permingeatite (an average of 10 spot analyses) on the basis of 8 apfu is $\left(\mathrm{Cu}_{3.00} \mathrm{Fe}_{0.04}\right)_{\Sigma 3.04} \mathrm{Sb}_{0.99}\left(\mathrm{Se}_{3.74} \mathrm{~S}_{0.23}\right)_{\Sigma 3.97}$.

During the study of other samples collected after the Škácha et al. [52] publication, permingeatite aggregates (Table S28) containing-in addition to S-small amounts of As (up to 0.08 apfu), $\mathrm{Ag}$ (to $0.05 \mathrm{apfu}$ ), $\mathrm{Hg}$ (to $0.01 \mathrm{apfu}$ ), and $\mathrm{Tl}$ (to $0.01 \mathrm{apfu}$ ) were detected. The empirical formula of permingeatite (the mean of 41 analyses on the basis of 8 apfu) can be expressed as $\left(\mathrm{Cu}_{3.01} \mathrm{Fe}_{0.02}\right)_{\Sigma 3.03}\left(\mathrm{Sb}_{1.00} \mathrm{As}_{0.01}\right)_{\Sigma 1.01}\left(\mathrm{Se}_{3.71} \mathrm{~S}_{0.24}\right)_{\Sigma 3.95}$. The Se vs. S diagram (Figure 44) shows a correlation with a slope of -1 , confirming partial S-Se-1 substitution.

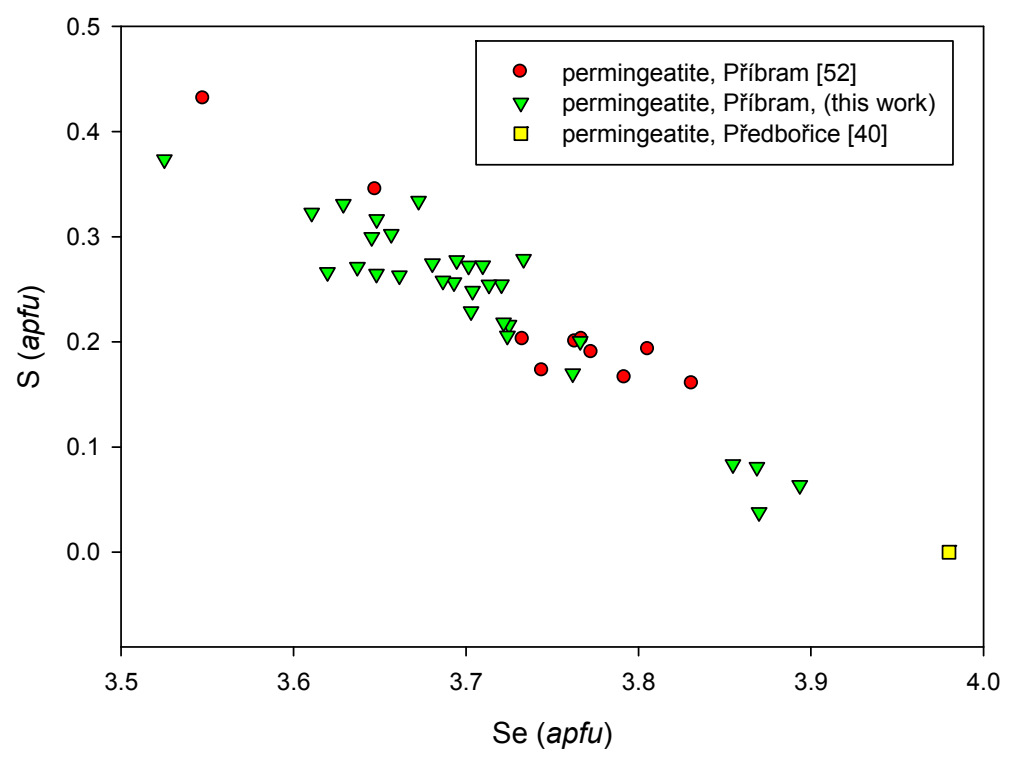

Figure 44. Se vs. S (apfu) graph for permingeatite.

X-ray powder diffraction data for permingeatite were presented by Škácha et al. [52]. The refined lattice parameters $\mathrm{a}=5.6323(2) \AA, \mathrm{c}=11.2354(7) \AA, \mathrm{V}=356.41(2) \AA^{3}$ (for the space group $142 \mathrm{~m}$ ) are in good agreement with the data of Johan et al. [40] for permingeatite from the type locality Předbořice, and are lower than values for a synthetic analogue of permingeatite [94]. The published data indicate that increasing contents of As and S result in lowering the volume of the unit-cell.

\subsubsection{Př́bramite-Chalcostibite Solid Solution $\mathrm{CuSbSe}_{2}-\mathrm{CuSbS}_{2}$}

The occurrence of minerals of the přibramite-chalcostibite solid solution series in the Příbram uranium ore district was first mentioned in the study of antimonselite of Škácha et al. [53]. Later on, these minerals were identified in additional samples, which resulted in their detailed characterization.

The new mineral príbramite-a Se-analogue of chalcostibite—was approved in 2016 (2015-127). The paper by Škácha et al. [46] provides a detailed characteristic, including its crystal structure solution $\left(R_{\mathrm{obs}}=0.0480 ; 342\right.$ unique reflections). Př́bramite has been found at the dump at shaft 16 (Př́bram-Háje) in two fragments of calcite gangue. In the first sample, přibramite forms locally-abundant polycrystalline aggregates up to $100 \mu \mathrm{m}$ in size, consisting of minute lens-shaped crystals (Figure 45). The tiemannite, antimonselite, dzharkenite, hakite, ferroselite, and a new $\mathrm{Hg}$-Cu-Sb selenide were identified in the association. The second sample contains anhedral príbramite grains up to $15 \mu \mathrm{m}$ across, intergrown with bytízite in association with chaméanite, giraudite, and bukovite. 

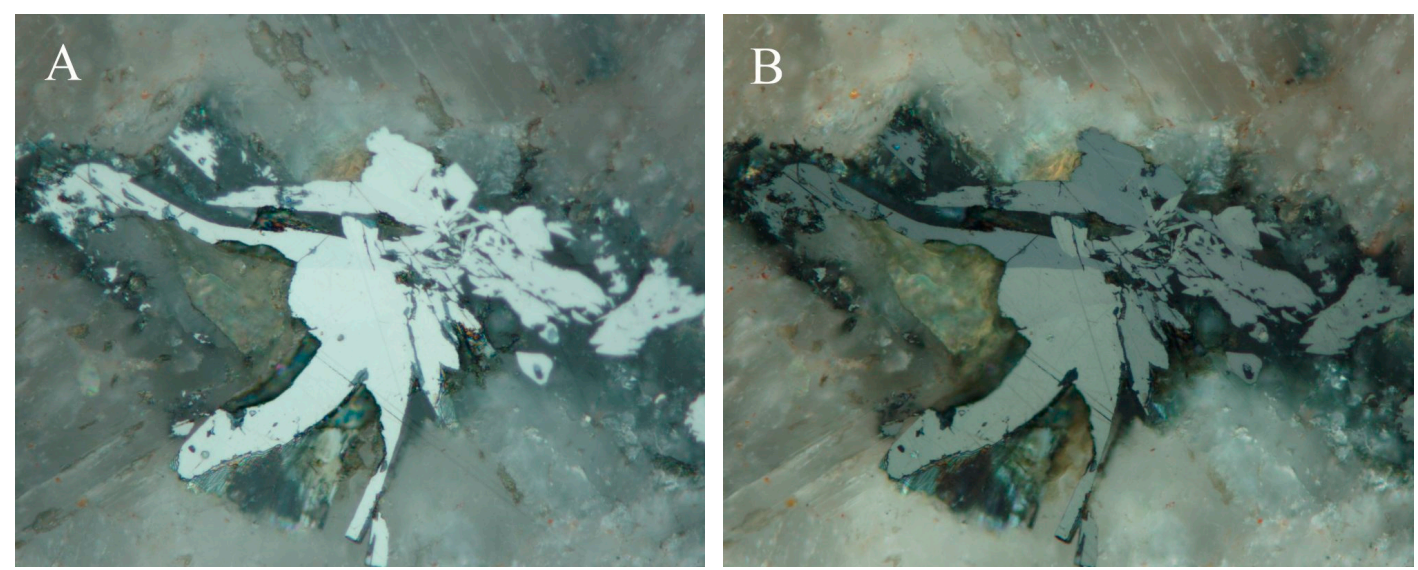

Figure 45. Prismatic přibramite crystals embedded in calcite. Reflected light, (A) one polarizer, (B) partly-crossed polarizers. FOV $210 \mu \mathrm{m}$. Příbram, a dump of shaft 16. Photo by P. Škácha.

In reflected light, prribramite is grey with a yellow shade, slightly lighter than Hg-rich hakite; it is distinctly anisotropic.

Study of přibramite chemical composition (Table S29) resulted in the observation of $\mathrm{SbAs}_{-1}$ substitution (up to $0.07 \mathrm{apfu}$ As) and $\mathrm{SeS}_{-1}$ substitution (0.09-0.51 apfu S). The diagram in Figure 46 indicates the range of probable príbramite-chalcostibite solid solution as supported by the present data. Copper dominates the cation position, but minor contents of $\mathrm{Ag}, \mathrm{Fe}, \mathrm{Pb}, \mathrm{Tl}$, and $\mathrm{Hg}$ (up to 0.0X apfu) were found locally. The empirical formula of pribramite (the mean of 53 analyses on the basis of 4 apfu) can be expressed as $\mathrm{Cu}_{1.00}\left(\mathrm{Sb}_{1.02} \mathrm{As}_{0.01}\right)_{\Sigma 1.03}\left(\mathrm{Se}_{1.81} \mathrm{~S}_{0.15}\right)_{\Sigma 1.96}$.

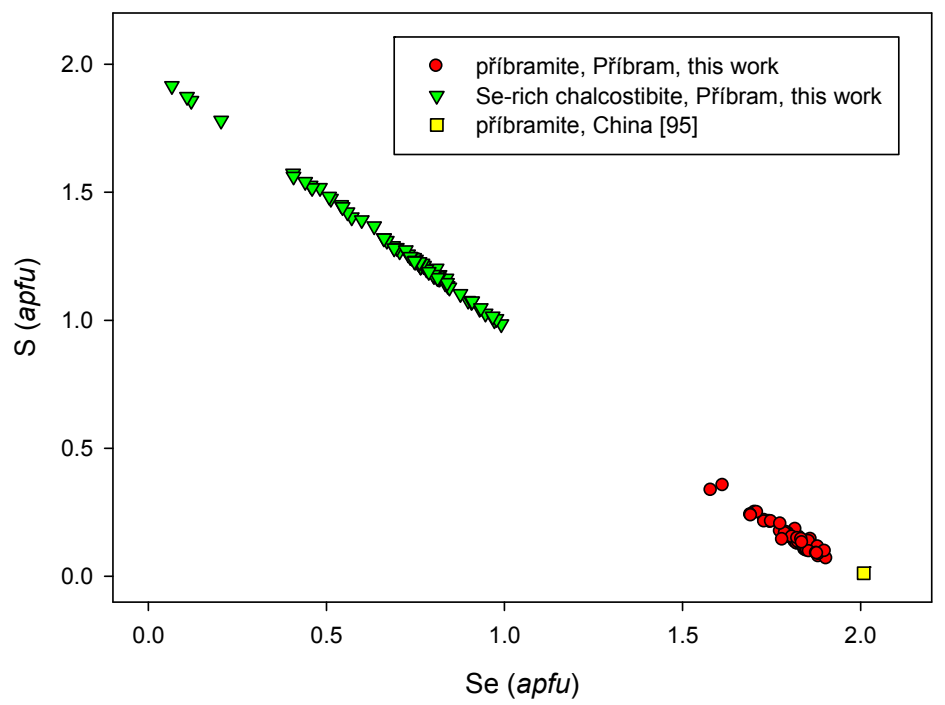

Figure 46. Se vs. S (apfu) graph for přibramite and Se-rich chalcostibite from Příbram and China.

An unnamed mineral from the U-Hg-Mo deposit in the Guizhou region, China that was observed as microscopic grains in carbonate veins carrying U-Se mineralization [95] probably corresponds to přibramite because of similar chemistry and reflected light properties.

Se-containing chalcostibite forms abundant lens-shaped-to-tabular crystals up to $10 \mu \mathrm{m}$ and their aggregates several $\mathrm{mm}$ across (Figure 47) in calcite gangue colored black by microscopic inclusions of sulphides and selenides. Antimonselite, luzonite, tennantite, and other minerals are present in the association. The megascopic aggregates have a pink shade and are very brittle. It is grey and strongly anisotropic in reflected light. 


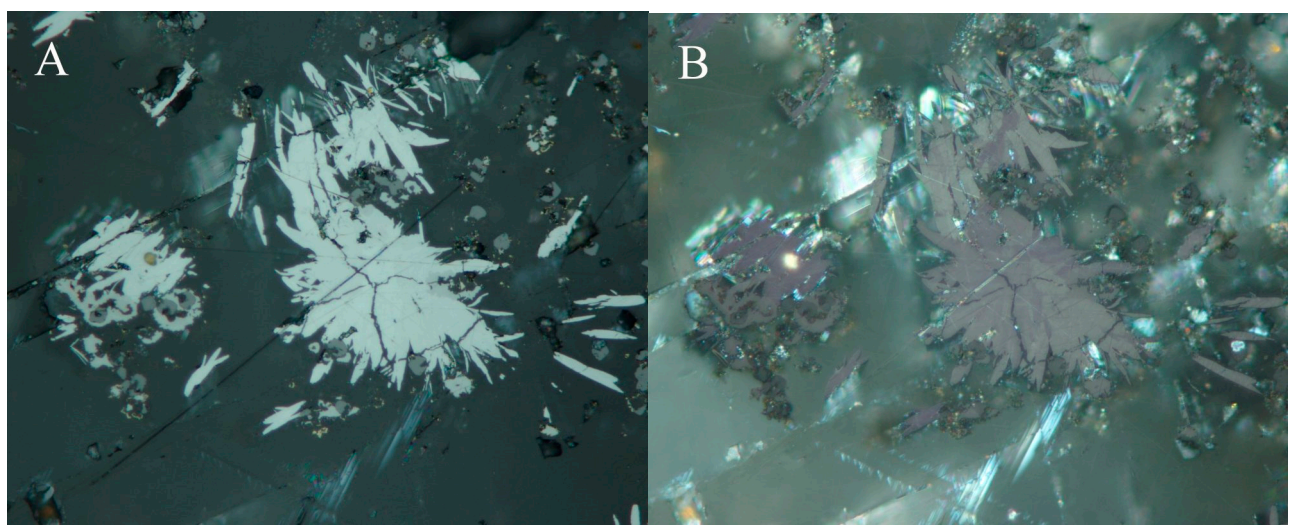

Figure 47. Lenticular euhedral grains of Se-rich chalcostibite (light grey), hakite (medium), and uraninite (dark grey) aggregates in calcite gangue. Reflected light, (A) one polarizer, and (B) partly-crossed polarizers. FOV $210 \mu \mathrm{m}$. Příbram, a dump of shaft 16. Photo by P. Škácha.

Backscattered electron images of chalcostibite show distinct zoning (Figure 48), due especially to a wide S-Se ${ }_{-1}$ substitution; the analysed Se contents range from 0.07 to 0.99 apfu (Figure 46). In the cation position, dominant $\mathrm{Cu}$ (Table S30) is accompanied by minor $\mathrm{Ag}$, $\mathrm{Fe}$, and $\mathrm{Pb}$ (up to 0.0X apfu); $\mathrm{Sb}$ shows a minor substitution (up to $0.01 \mathrm{apfu}$ ) by As. The empirical formula of Se-chalcostibite (the mean of 72 analyses on the basis of 4 apfu) can be expressed as $\mathrm{Cu}_{1.00}\left(\mathrm{Sb}_{0.99} \mathrm{As}_{0.02}\right)_{\Sigma 1.01}\left(\mathrm{Se}_{1.29} \mathrm{~S}_{0.70}\right)_{\Sigma 1.99}$.

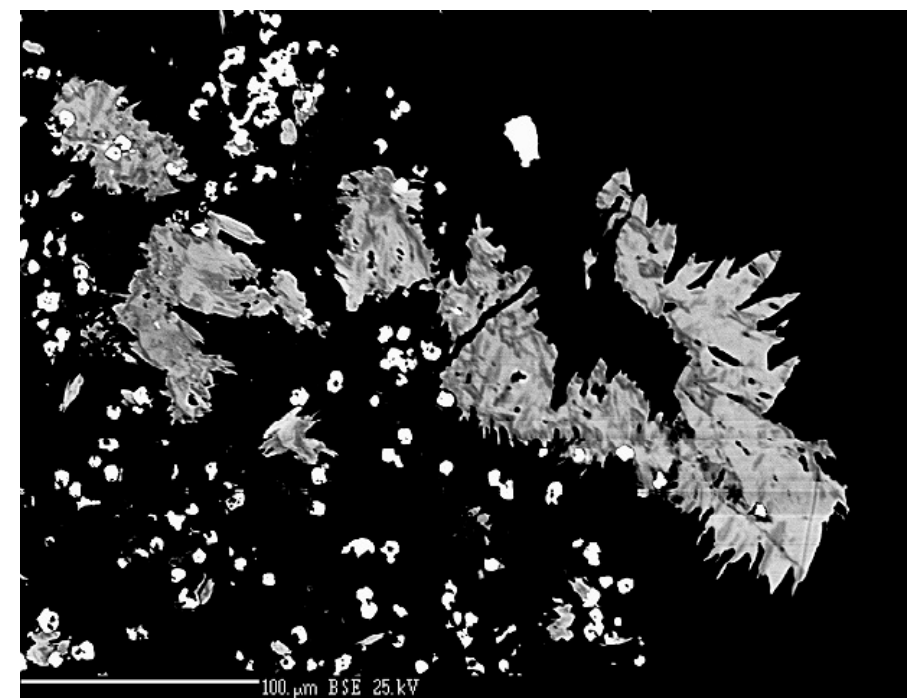

Figure 48. Zonation of Se-rich chalcostibite euhedral aggregates caused by variable Se-S content. BSE photo. Přibram, a dump of shaft 16. Photo by J. Sejkora and P. Škácha.

\subsubsection{Sabatierite, $\mathrm{Cu}_{6} \mathrm{TlSe}_{4}$}

Sabatierite with the idealized formula $\mathrm{Cu}_{6} \mathrm{TlSe}_{4}$ was first described by Johan et al. [33] from the Bukov deposit. Based on a study of powder diffraction data, Berger [96] proposed a different formula $\left(\mathrm{Cu}_{4} \mathrm{TlSe}_{3}\right)$, but his assumption is not confirmed by chemical study. The formula and crystal structure of sabatierite are not yet known.

In the studied material from Př́bram, sabatierite was observed as a single anhedral grain $30 \mu \mathrm{m}$ in size, intergrown with bukovite (Figure 49) in association with berzelianite and eskebornite. In reflected light, sabatierite is creamy white with a pinkish shade. 


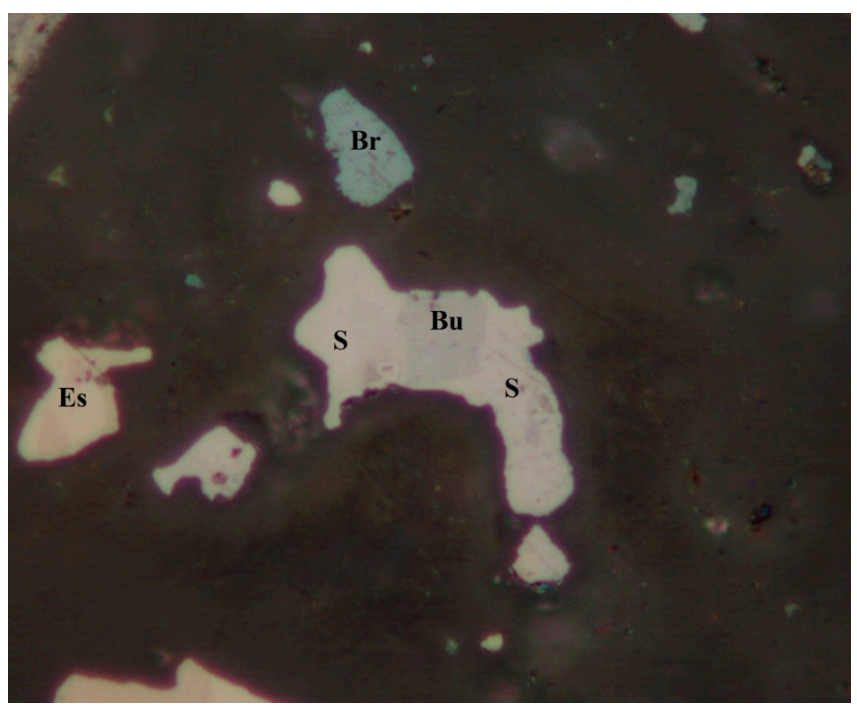

Figure 49. Brown-grey sabatierite is intergrown with dark grey bukovite. Reflected light, one polarizer. FOV $90 \mu \mathrm{m}$. Příbram, a dump of the shaft 16. Photo by P. Škácha.

Study of the chemical composition of the mineral (Table S31) shows that it contains dominant $\mathrm{Tl}, \mathrm{Cu}$, and Se, and minor Ag (0.01-0.39 apfu), Fe (0.01-0.03 apfu), and S (0.01-0.03 apfu). The empirical formula (the mean of four analyses) on the basis of 11 apfu is $\left(\mathrm{Cu}_{6.16} \mathrm{Ag}_{0.12}\right)_{\Sigma 6.28}\left(\mathrm{Tl}_{0.92}\right.$ $\left.\mathrm{Fe}_{0.02}\right)_{\Sigma .94}\left(\mathrm{Se}_{3.67} \mathrm{~S}_{0.12}\right)_{\Sigma 3.79}$; this corresponds to stoichiometry proposed by Johan et al. [33]. The elevated Ag content in the studied sample is interesting. One of the spot analyses (Table S32) indicates a possible solid solution approaching an unnamed Ag-Cu-Tl selenide described by Sejkora et al. [15] from the Zálesí deposit. The diagram of Ag vs. Cu contents (Figure 50) for both phases from Příbram and Zálesí exhibit a negative correlation of these elements.

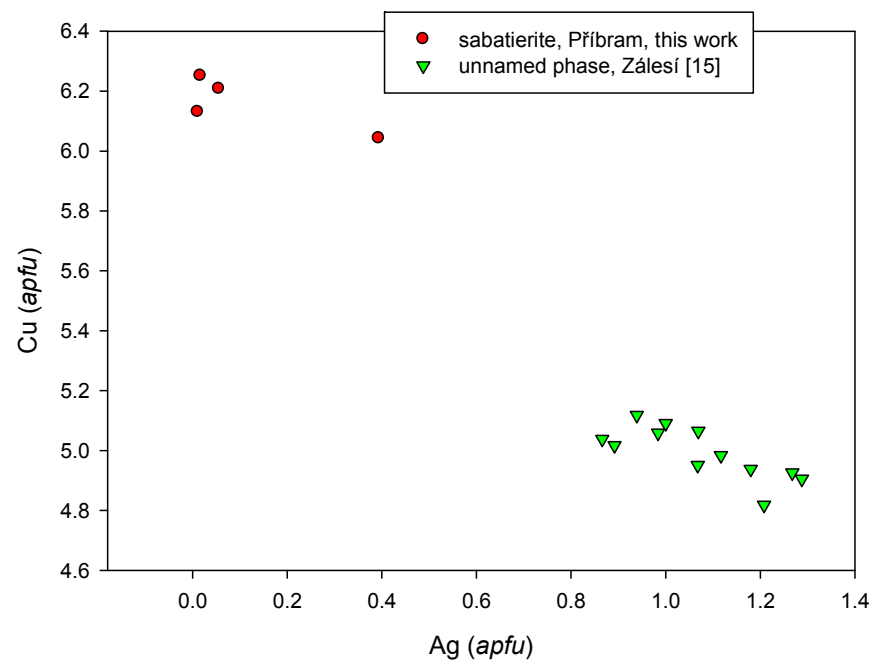

Figure 50. Ag vs. $\mathrm{Cu}(a p f u)$ graph for sabatierite from Příbram and an unnamed Ag-Cu-Tl-Se phase from Zálesí.

\subsubsection{Tetrahedrite Group}

The tetrahedrite group is the most complex isotypic series among the sulphosalts in nature. It is caused by the multiplicity of iso- and heterovalent substitutions [97]. A simplified general formula for minerals of the tetrahedrite group can be expressed according to Moëlo et al. [97] as ${ }^{[I I I]} \mathrm{A}_{6}{ }^{[\mathrm{VV}]}(\mathrm{B}, \mathrm{C})_{6}{ }^{[\mathrm{III}]} \mathrm{X}_{4}{ }^{[\mathrm{IV}]} \mathrm{Y}_{12}{ }^{[\mathrm{VI}]} \mathrm{Z}_{1}$, where $A$ is $\mathrm{Cu}$ or $\mathrm{Ag}$ in triangular coordination; $B$ is $\mathrm{Cu}^{1+}$ or $\mathrm{Ag}$ in 
tetrahedral coordination, $\mathrm{C}$ is generally a divalent metal (typically Fe or $\mathrm{Zn}$, but also $\mathrm{Hg}, \mathrm{Mn}, \mathrm{Cd}, \mathrm{Cu}^{2+}$, etc.) in the same coordination as $B ; X$ is $\mathrm{Sb}, \mathrm{As}, \mathrm{Bi}$, or Te in trigonal pyramidal coordination; $\mathrm{Y}$ is $\mathrm{S}$ or Se in tetrahedral coordination, and $Z$ is $S$ or Se in special octahedral coordination. Structural studies confirmed the presence of vacancies or interstitial atoms (e.g. $\mathrm{Cu}$ ), or heterovalent substitutions due to the incorporation of $\mathrm{Fe}^{3+}$ or $\mathrm{Te}^{4+}$.

The classification of the tetrahedrite group of minerals is in need of review and updating, but this has not been done to date $[97,98]$. Currently, the divalent substituents $C$ in tetrahedral coordination are not generally distinguished in the IMA-approved definitions of the minerals, with the exception of Hg-dominant hakite, although varieties with different dominant $C$ cations are distinguished in the literature [54]. However, the dominant $C$ cation in these minerals may be $\mathrm{Zn}, \mathrm{Fe}, \mathrm{Hg}, \mathrm{Cu}$, or $\mathrm{Cd}$, and here we distinguish these cases using the dominant-constituent rule [99]. Hakite has been originally described as an $\mathrm{Hg}$ variety, but for the matter of classification, Škácha et al. [54] propose the application of the dominant rule (on the atomic basis) for solid-solutions of the members of the tetrahedrite group. That is why we distinguish $\mathrm{Zn-}, \mathrm{Fe}-, \mathrm{Hg}-, \mathrm{Cu}-$, and $\mathrm{Cd}-$ members in the following text.

\subsubsection{Giraudite-Tennantite Solid Solution, $\mathrm{Cu}_{6}\left[\mathrm{Cu}_{4}(\mathrm{Fe}, \mathrm{Zn})_{2}\right] \mathrm{As}_{4} \mathrm{Se}_{13}-\mathrm{Cu}_{6}\left[\mathrm{Cu}_{4}(\mathrm{Fe}, \mathrm{Zn})_{2}\right] \mathrm{As}_{4} \mathrm{~S}_{13}$}

Minerals of the giraudite-tennantite solid solution were rare, they were found in only some samples. Cu-giraudite forms rims around hakite, and it is intergrown with berzelianite (Figure 51) or its aggregates up to $400 \mu \mathrm{m}$ long are intergrown with chaméanite in association with prribramite, bytízite, and Tl-selenides. In another sample, anhedral Hg-giraudite grain about $30 \mu \mathrm{m}$ across is replaced by later $\mathrm{Cu}$-selenide (Figure 52); this is a unique case at the locality that a mineral of the tetrahedrite group is older than the $\mathrm{Cu}$-selenides. Both giraudite types are of a light grey color with a brownish shade in reflected light.

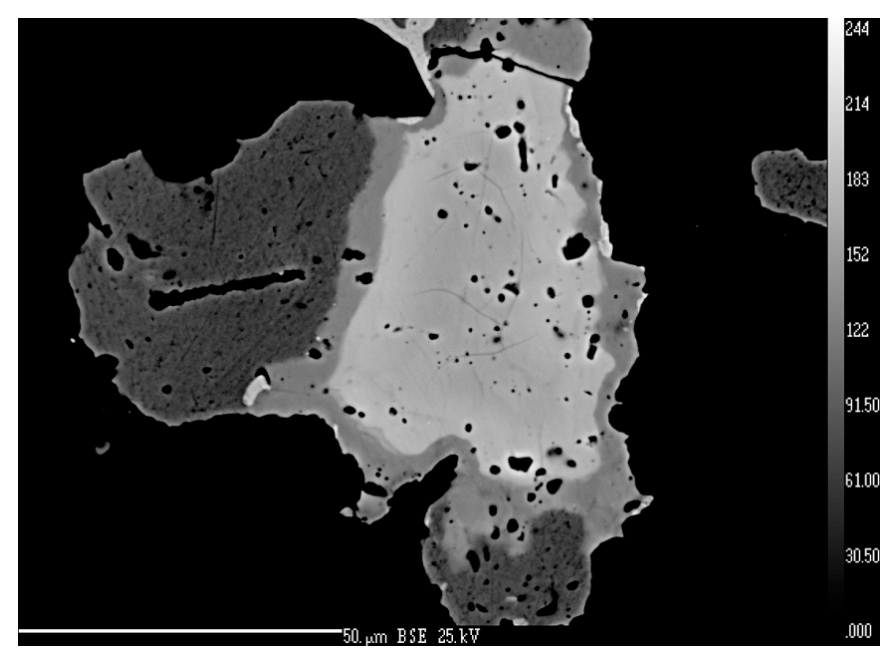

Figure 51. The core of aggregate formed by hakite (light grey) is rimmed by giraudite (grey); berzelianite (dark grey) is the youngest mineral in the association. BSE photo. Přibram, a dump of shaft 16. Photo by J. Sejkora and P. Škácha.

In its chemical composition, giraudite shows typical substitutions of the tetrahedrite group. Two compositional types were identified: $\mathrm{Cu}$ - and $\mathrm{Hg}$-giraudite (Table S32). Cu-giraudite (22 analyses) also contains $\mathrm{Ag}$ in the $A$ position (up to $0.23 \mathrm{apfu}$ ) in addition to $\mathrm{Cu}$; the $B$ position is fully occupied by $\mathrm{Cu}$. The $C$ position is dominated by $\mathrm{Cu}(1.6-2.39$ apfu), with a small $\mathrm{Hg}$ content (up to 0.83 apfu), Fe (up to $1.40 a p f u$ ), Zn (up to 0.11 apfu), and Cd (up to 0.03 apfu). Arsenic in the position $X$ is substituted by Sb (up to 0.71 apfu), and locally, Te (up to 0.43 apfu). The highest $S$ contents in the anion positions do not exceed $1.38 \mathrm{apfu}$. The empirical formula of Cu-giraudite based on 29 apfu is $\left(\mathrm{Cu}_{5.82} \mathrm{Ag}_{0.18}\right)_{\Sigma 6.00} \mathrm{Cu}_{4.00}\left(\mathrm{Cu}_{1.76} \mathrm{Fe}_{0.34} \mathrm{Hg}_{0.07} \mathrm{Zn}_{0.03}\right)_{\Sigma 2.20}\left(\mathrm{As}_{3.27} \mathrm{Sb}_{0.65}\right)_{\Sigma 3.92}\left(\mathrm{Se}_{12.82} \mathrm{~S}_{0.05}\right)_{\Sigma 12.87}$. 


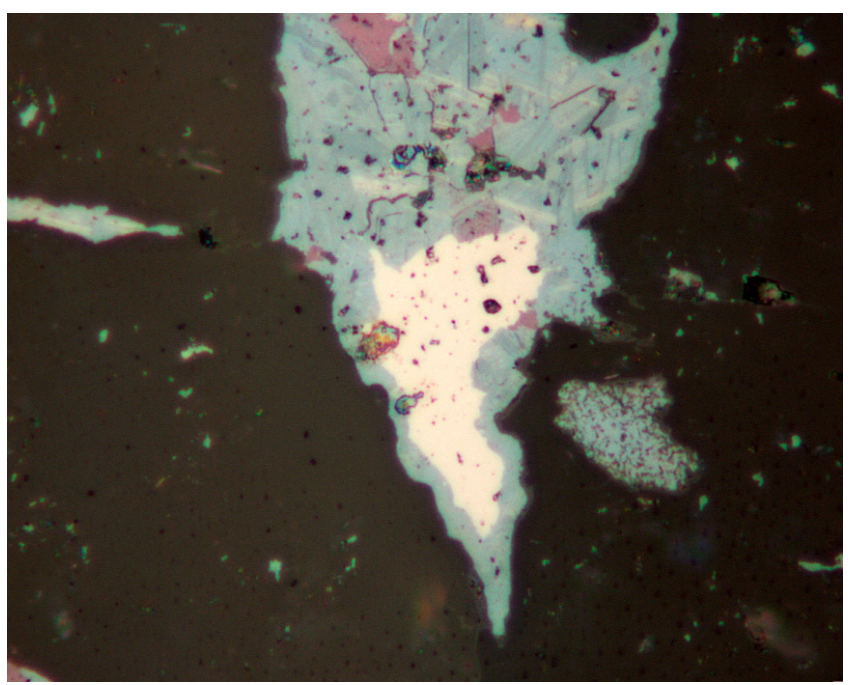

Figure 52. Yellowish-pink giraudite anhedral grain replacing by blue-green berzelianite which is partly replaced by violet umangite. Reflected light, one polarizer. FOV $210 \mu \mathrm{m}$. Příbram, a dump of shaft 16. Photo by P. Škácha.

In the $A$ position, $\mathrm{Hg}$-giraudite (two analyses) contains $\mathrm{Ag}(0.22-0.23$ apfu), in addition to $\mathrm{Cu}$. The $B$ position is fully occupied by $\mathrm{Cu}$. The $C$ position is filled mainly by $\mathrm{Hg}(1.3 \mathrm{apfu})$, minor $\mathrm{Cd}(0.2 \mathrm{apfu})$, and $\mathrm{Zn}(0.12 \mathrm{apfu})$. In the $X$ position, in addition to arsenic, is a low Sb content (0.19-0.44 apfu). Sulphur contents in anion positions vary around $1.6 \mathrm{apfu}$. The empirical formula of Hg-giraudite based on 29 apfu is $\left(\mathrm{Cu}_{5.78} \mathrm{Ag}_{0.22}\right)_{\Sigma 6.00} \mathrm{Cu}_{4.00}\left(\mathrm{Hg}_{1.29} \mathrm{Cu}_{0.41} \mathrm{Cd}_{0.22} \mathrm{Zn}_{0.12}\right)_{\Sigma 2.04}\left(\mathrm{As}_{3.55} \mathrm{Sb}_{0.31}\right)_{\Sigma 3.86}\left(\mathrm{Se}_{11.48} \mathrm{~S}_{1.61}\right)_{\Sigma 13.09}$.

Giraudite is a very rare member of the tetrahedrite group. It was reported from the hydrothermal Chaméane deposits [77] and Alberoda [19]. It is also mentioned from some epithermal deposits in Mexico and USA. Figure 53 shows an obvious negative correlation between As and $\mathrm{Sb}$ for various minerals of the tetrahedrite group, including giraudite from Přibram.

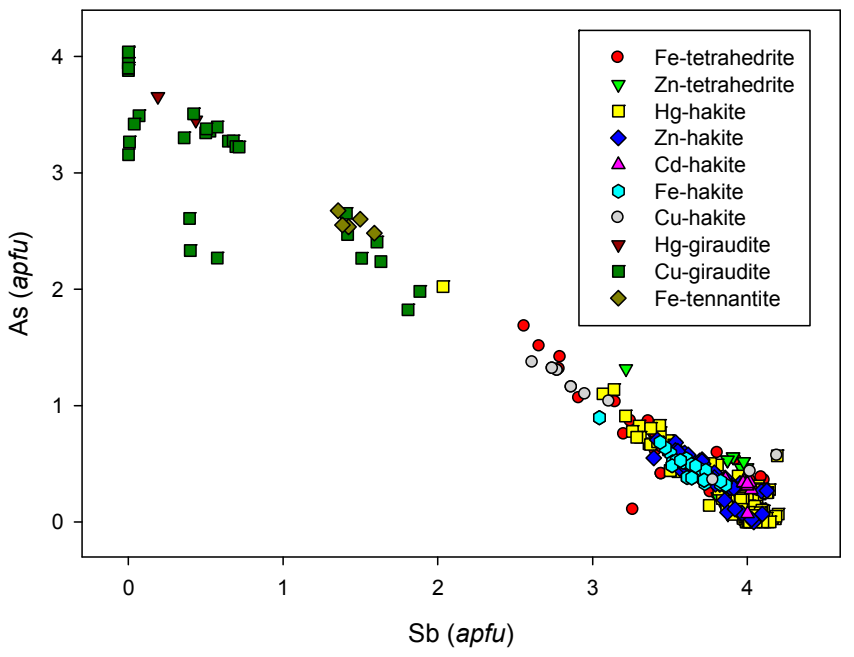

Figure 53. Sb vs. As (apfu) graph for tetrahedrite group of minerals from Příbram.

Fe-tennantite is very rare in the studied material. It forms thin irregular rims about $30 \times 10 \mu \mathrm{m}$ around tetrahedrite aggregate (Figure 54) in association with luzonite, antimonselite, and Se-rich chalcostibite. In reflected light, tennantite is similar to tetrahedrite. It is grey, without notable anisotropy. 


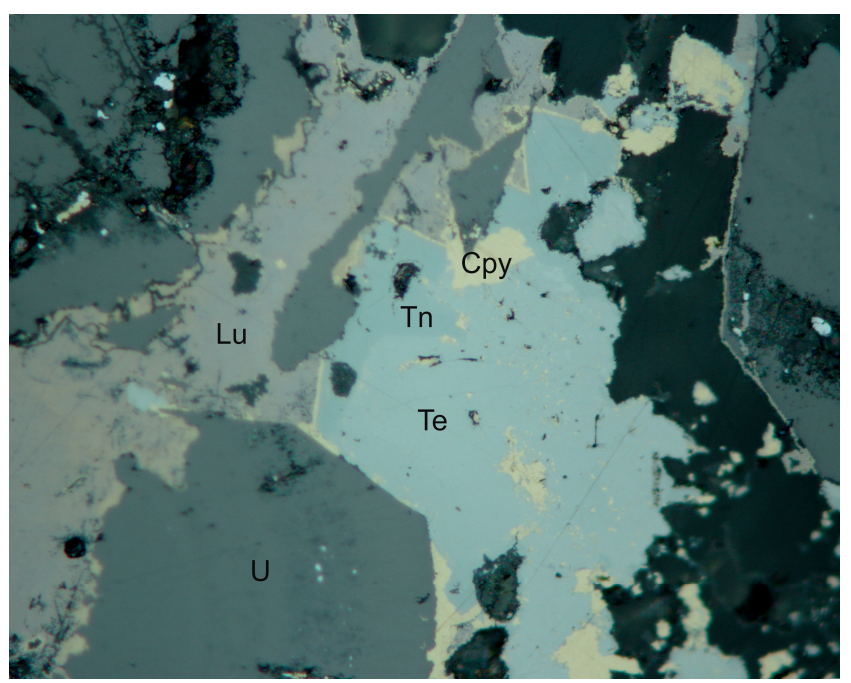

Figure 54. Dark grey Fe-tennantite (Tn) overgrowing grey Fe-tetrahedrite (Te) in association with pinkish luzonite (Lu), chalcopyrite (Cpy), and uraninite (U). Reflected light, one polarizer. FOV 210 $\mu \mathrm{m}$. Př́ibram, a dump of the shaft no. 16. Photo P. Škácha.

Tennantite is chemically relatively homogeneous (Table S33) and shows substitutions typical for the tetrahedrite group. In position $A$ are minor amounts of $\mathrm{Ag}$ (up to $0.01 \mathrm{apfu}$ ) in addition to the dominant $\mathrm{Cu}$. The $B$ position is fully occupied by $\mathrm{Cu}$. Fe $(1.16-1.39 a p f u)$ is predominant in the $C$ position, accompanied by $\mathrm{Cu}(0.52-0.76$ apfu) and very low $\mathrm{Pb}$ (up to $0.01 \mathrm{apfu}$ ). Position $X$ is dominated by As (2.48-2.67 apfu), which is significantly substituted by Sb (1.35-1.59 apfu). Sulphur in the anion position is partly substituted by Se (0.18-0.33 apfu). The chemical composition of Fe-tennantite (the mean of five analyses) can be expressed on the basis of 29 apfu by the following formula: $\left(\mathrm{Cu}_{5.99} \mathrm{Ag}_{0.01}\right)_{\Sigma 6.00} \mathrm{Cu}_{4.00}\left(\mathrm{Fe}_{1.26} \mathrm{Cu}_{0.62}\right)_{\Sigma 1.88}\left(\mathrm{As}_{2.57} \mathrm{Sb}_{1.45}\right)_{\Sigma 4.02}\left(\mathrm{~S}_{12.84} \mathrm{Se}_{0.25}\right)_{\Sigma 13.09}$.

Litochleb et al. [49] described from Bytíz allotriomorphic to hypidiomorphic tetrahedrite-tennantite aggregates, which are replaced by Sb-rich chalcopyrite. Similar to the studied samples, the mineral is Fe-rich tennantite with a significant SeS-1 substitution [49].

\subsubsection{Hakite-Tetrahedrite Solid Solution, $\mathrm{Cu}_{6}\left[\mathrm{Cu}_{4}(\mathrm{Hg}, \mathrm{Zn})_{2}\right] \mathrm{Sb}_{4} \mathrm{Se}_{13}-\mathrm{Cu}_{6}\left[\mathrm{Cu}_{4}(\mathrm{Fe}, \mathrm{Zn})_{2}\right] \mathrm{Sb}_{4} \mathrm{~S}_{13}$}

Hakite and its sulphur analogue tetrahedrite are relatively common in the studied samples. In contrast to tetrahedrite, hakite is more common in microscopic form, but locally, aggregates up to several $\mathrm{mm}$ in size were observed. At present, Škácha et al. [54] studied in detail hakite from Přibram. They distinguish three chemical types of hakite: $\mathrm{Hg}-, \mathrm{Zn}-$, and Cd-hakite. Most detailed data were obtained for the most common Hg-hakite; its refined unit-cell parameters (space group $I-43 m) \mathrm{a}=10.8783(3) \AA, \mathrm{V}=1287.3(1) \AA^{3}$ agree very well with the published data for Hg-hakite from Předbořice [39]. With the use of precession electron diffraction tomography (PED), the Hg-hakite crystal structure was solved and its relationship to the tetrahedrite group was confirmed.

After extending the data set used by Škácha et al. [54] by analyses of the new samples, it is possible to define five chemical types of hakite, depending on filling the $C$ position by the respective elements: $\mathrm{Hg}-, \mathrm{Zn}-, \mathrm{Cd}-, \mathrm{Fe}-$, and $\mathrm{Cu}$-hakite.

Hg-hakite is the prevailing type, which forms relatively abundant allotriomorphic aggregates together with Zn-hakite up to several mm across (Figures 13 and 55). In one case, Hg-hakite formed an aggregate of well-formed idiomorphic crystals up to $100 \mu \mathrm{m}$ [54]. Both of the hakite types occur especially in association with berzelianite, or rarely, with athabascaite. In all analysed Hg-hakite samples, $\mathrm{Cu}$ predominates at the $A$ site. It contains up to $1.93 \mathrm{apfu} \mathrm{Ag}$, which is more than that observed in other types of hakite (Figure 56). The range of Ag content in the Hg-hakite is 0.04-1.93 apfu $(n=122)$. The $B$ position is fully occupied by $\mathrm{Cu}$ in most cases. In the $C$ position, $\mathrm{Hg}(0.72-1.98$ apfu 
is predominant above other elements (Zn up to 0.96 apfu; $\mathrm{Cu}$ and $\mathrm{Cd}$ up to 0.71 apfu, and Fe up to $0.59 \mathrm{apfu}$ ). The antimony contents vary in the range 2.03-4.20 apfu; less common is As (up to 2.02 apfu). The measured S contents are 0.01-4.69 apfu, and the average Se content is 11.67 apfu. On the basis of the mean of 122 EPM analyses (Table S34), the empirical formula is based on 29 apfu and can be expressed as $\left(\mathrm{Cu}_{5.65} \mathrm{Ag}_{0.35}\right)_{\Sigma 6.00} \mathrm{Cu}_{4.00}\left(\mathrm{Hg}_{1.72} \mathrm{Zn}_{0.16} \mathrm{Fe}_{0.07} \mathrm{Cu}_{0.05} \mathrm{Cd}_{0.05}\right)_{\Sigma 2.05}\left(\mathrm{Sb}_{3.89} \mathrm{As}_{0.27}\right)_{\Sigma 4.16}\left(\mathrm{Se}_{11.67} \mathrm{~S}_{1.13}\right)_{\Sigma 12.80}$.

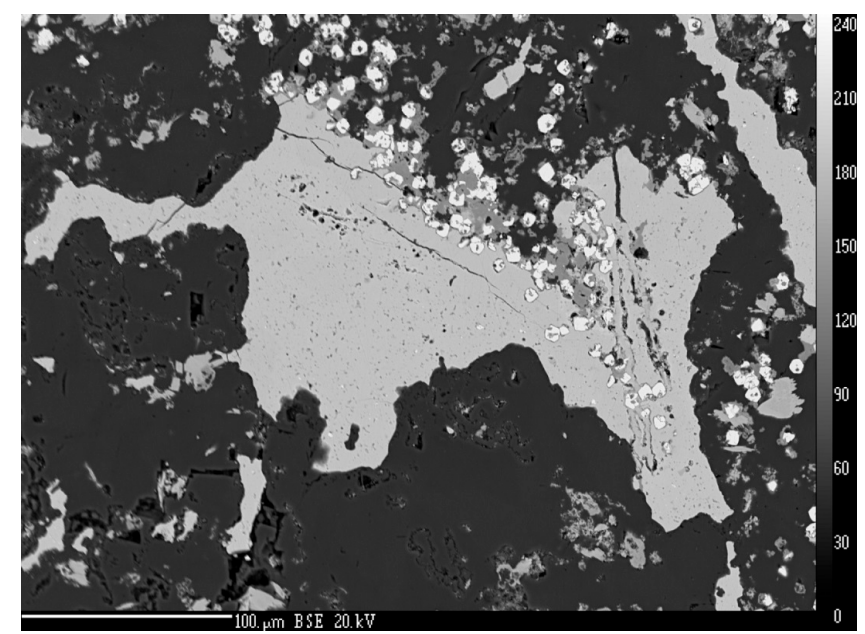

Figure 55. Homogeneous Hg-hakite (light grey) in association with uraninite (white) and Fe-tetrahedrite (dark grey). BSE photo. Přibram, a dump of shaft 16. Photo by J. Sejkora and P. Škácha.

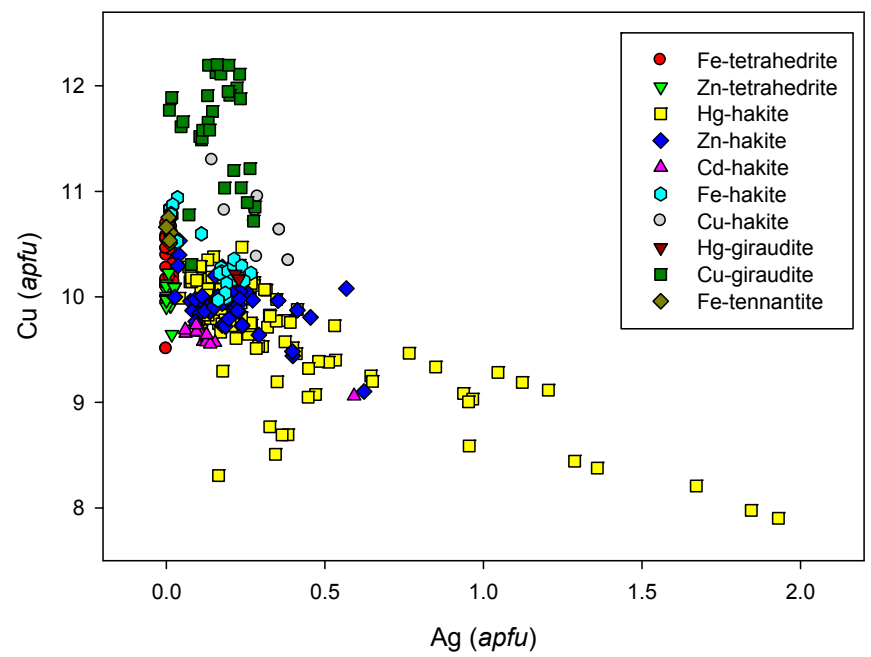

Figure 56. Ag vs. $\mathrm{Cu}(a p f u)$ graph for tetrahedrite group of minerals from Příbram.

Zn-hakite was observed as irregular aggregates up to several $\mathrm{mm}$ in size in association with Hg-hakite, clausthalite, bukovite (Figure 18), and berzelianite. It also occurs together with Hg-hakite and Zn-tetrahedrite as a part of zoned idiomorphic crystals up to $100 \mu \mathrm{m}$ [54]. Minor Ag contents not exceeding 0.62 apfu were observed in the $A$-site during the study of its chemical composition (Table S35); the B-site is fully occupied by Cu. $\mathrm{Hg}$ (up to 0.80 apfu), Fe (up to 0.59 apfu), and Cd (up to $0.47 \mathrm{apfu})$, in addition to the dominant $\mathrm{Zn}(0.60-1.88 \mathrm{apfu})$, were observed in the $C$ site. In the $X$ position, the dominant $\mathrm{Sb}$ is accompanied by As (up to $0.71 \mathrm{apfu}$ ), and in the anion site, Se is partly substituted by S (0.07-4.52 apfu). The empirical Zn-hakite formula (the mean of 53 analyses) on the basis of 29 apfu is $\left(\mathrm{Cu}_{5.80} \mathrm{Ag}_{0.20}\right)_{\Sigma 6.00} \mathrm{Cu}_{4.00}\left(\mathrm{Zn}_{1.46} \mathrm{Hg}_{0.31} \mathrm{Cu}_{0.12} \mathrm{Cd}_{0.07}\right)_{\Sigma 1.96}\left(\mathrm{Sb}_{3.78} \mathrm{As}_{0.38}\right)_{\Sigma 4.16}\left(\mathrm{Se}_{11.94} \mathrm{~S}_{0.91}\right)_{\Sigma 12.85}$.

Cd-hakite forms very rare allotriomorphic aggregates up to $50 \mu \mathrm{m}$ in size, intergrown with clausthalite (Figure 21). Its aggregates are locally replaced by lath-shaped cadmoselite crystals; the 
replacement starts from the center of aggregates. According to chemical analyses (Table S36), the $A$ site in Cd-hakite contains minor amounts of Ag (0.06-0.59 apfu) in addition to the dominant Cu. The $B$ site is fully occupied by $\mathrm{Cu}$. In the $C$ position, $\mathrm{Cd}$ in the range of 1.05-1.54 apfu is accompanied by $\mathrm{Zn}$ (up to $0.89 \mathrm{apfu}$ ) and $\mathrm{Hg}$ (up to $0.57 \mathrm{apfu}$ ). Sb shows a substitution by As (up to 0.37 apfu), and in the anion group, the dominant Se is locally accompanied by S contents in the range 0.67-4.54 apfu. The chemical composition of $\mathrm{Cd}$-hakite (mean of 14 analyses) corresponds to the empirical formula $\left(\mathrm{Cu}_{5.60} \mathrm{Ag}_{0.14}\right)_{\Sigma 5.74} \mathrm{Cu}_{4.00}\left(\mathrm{Cd}_{1.37} \mathrm{Hg}_{0.45} \mathrm{Zn}_{0.15}\right)_{\Sigma 1.97}\left(\mathrm{Sb}_{3.99} \mathrm{As}_{0.32}\right)_{\Sigma 4.31}\left(\mathrm{Se}_{9.95} \mathrm{~S}_{3.05}\right)_{\Sigma 13.00}$.

Fe-hakite has been found very rarely as allotriomorphic aggregates up to $300 \times 30 \mu \mathrm{m}$ in size, in association with chalcopyrite, Cu-hakite, chaméanite, giraudite, permingeatite, tetrahedrite, bukovite, bytízite, and přibramite (Figure 57). During the study of the chemical composition (Table S37), dominant $\mathrm{Cu}$ contents were found in the $A$ position accompanied by $\mathrm{Ag}$ in the range 0.01-0.29 apfu and, exceptionally, by Tl (up to $0.02 a p f u$ ). The $B$ position is fully occupied by $\mathrm{Cu}$, and in the $C$ position, in addition to the dominant Fe (0.50-1.33 apfu), and mainly $\mathrm{Zn}(0.15-0.72 a p f u)$, and $\mathrm{Hg}(0.00-0.52$ apfu) occur. In the $X$ position is $\mathrm{Sb}(2.61-3.86$ apfu), partly replaced by As (0.36-1.37 apfu). Sulphur contents in the $Y+Z$ positions are low (0.04-0.47 apfu). The empirical formula of Fe-hakite based on 29 apfu (the mean of 27 analyses) is $\left(\mathrm{Cu}_{5.87} \mathrm{Ag}_{0.13}\right)_{\Sigma 6.00} \mathrm{Cu}_{4.00}\left(\mathrm{Fe}_{0.92} \mathrm{Cu}_{0.55} \mathrm{Zn}_{0.45} \mathrm{Hg}_{0.21}\right)_{\Sigma 2.13}\left(\mathrm{Sb}_{3.63} \mathrm{As}_{0.47}\right)_{\Sigma 4.10}\left(\mathrm{Se}_{10.66} \mathrm{~S}_{2.11}\right)_{\Sigma 12.77}$.

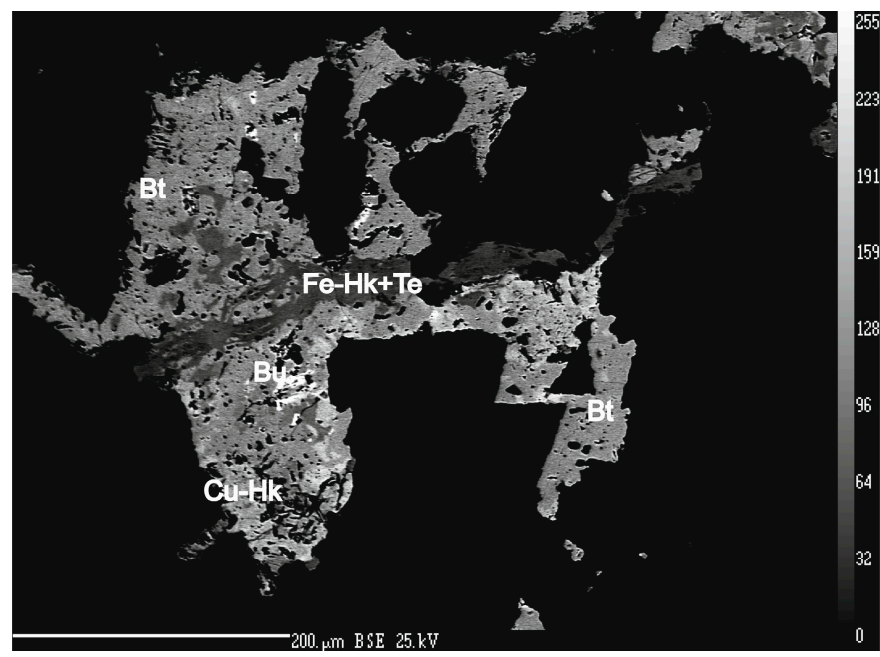

Figure 57. The complicated aggregate of dark grey Fe-hakite (Fe-Hk), Cu-hakite (Cu-Hk) and Fe-tetrahedrite (Te), bytízite (Bt), and bukovite $(\mathrm{Bu})$. BSE photo. Příbram, a dump of shaft 16 . Photo by J. Sejkora and P. Škácha.

Cu-hakite forms very rare, small allotriomorphic aggregates intergrown with bytízite in association with Fe-hakite, chaméanite, giraudite, bukovite, tetrahedrite, and příbramite (Figure 57). In its chemical composition (Table S38), the dominant $\mathrm{Cu}$ in the $A$ position is accompanied by Ag (0.14-0.39) and, rarely, Tl (up to $0.015 a p f u$ ). The $B$ position is fully occupied by $\mathrm{Cu}$, and in the $C$ position, minor Fe (0.06-0.82 apfu) and $\mathrm{Zn}(0.03-0.23 a p f u)$ accompany the dominant $\mathrm{Cu}$ (0.67-1.44 apfu). In the $X$ position, the dominant Sb (2.61-4.02 apfu) is-in part-replaced by As (0.36-1.37apfu). Isomorphic substitution by $S$ in the $Y+Z$ positions is low (0.04-0.47apfu). The empirical formula of Cu-hakite on the basis of 29 apfu (the mean of eight analyses) is $\left(\mathrm{Cu}_{5.72} \mathrm{Ag}_{0.28}\right)_{\Sigma 6.00} \mathrm{Cu}_{4.00}\left(\mathrm{Cu}_{1.02} \mathrm{Hg}_{0.38} \mathrm{Fe}_{0.45} \mathrm{Zn}_{0.19}\right)_{\Sigma 2.04}\left(\mathrm{Sb}_{3.10} \mathrm{As}_{1.01}\right)_{\Sigma 4.11}\left(\mathrm{Se}_{12.74} \mathrm{~S}_{0.12}\right)_{\Sigma 12.86}$.

Tetrahedrite is abundant in the studied material. It is a common component of hypidiomorphic to idiomorphic aggregates several $\mathrm{mm}$ in size (Figure 57), sometimes intergrown with later chalcopyrite. Tetrahedrite was also observed as zoned granular aggregates with hakite (Figure 58) or as rims around chalcocite (Figure 59); in these aggregates, tetrahedrite usually forms the outer parts of grains. In reflected light, it is grey, isotropic, and slightly darker than hakite. 


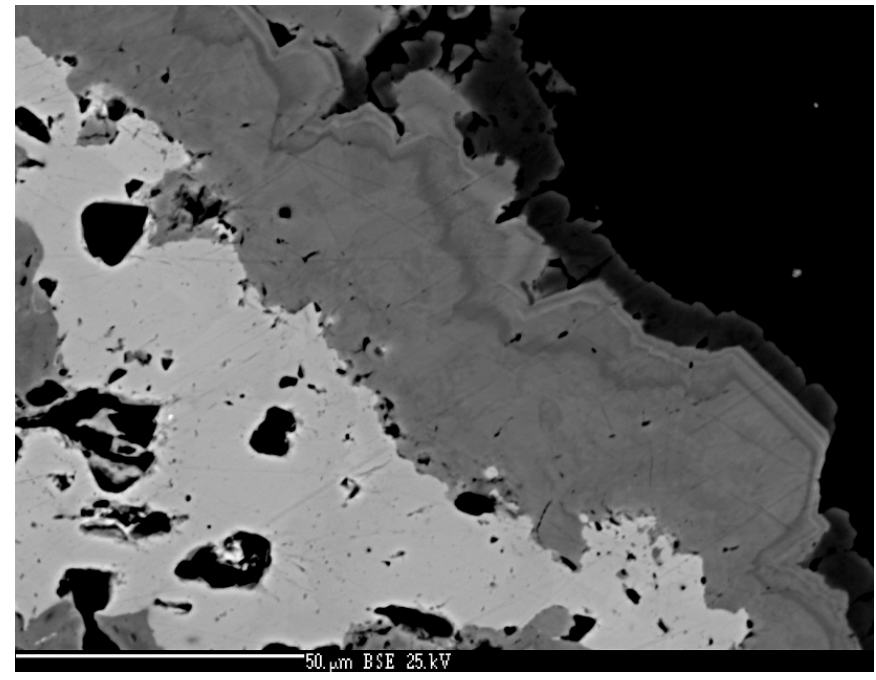

Figure 58. Earlier Hg-hakite (light grey) overgrown by later zonal Fe-tetrahedrite (middle grey) with the latest chalcopyrite (dark grey). Zonality in Fe-tetrahedrite is caused by a fluctuation of $\mathrm{Zn}$ and $\mathrm{Hg}$ content. BSE photo. Přibram, a dump of shaft 16. Photo by J. Sejkora and P. Škácha.

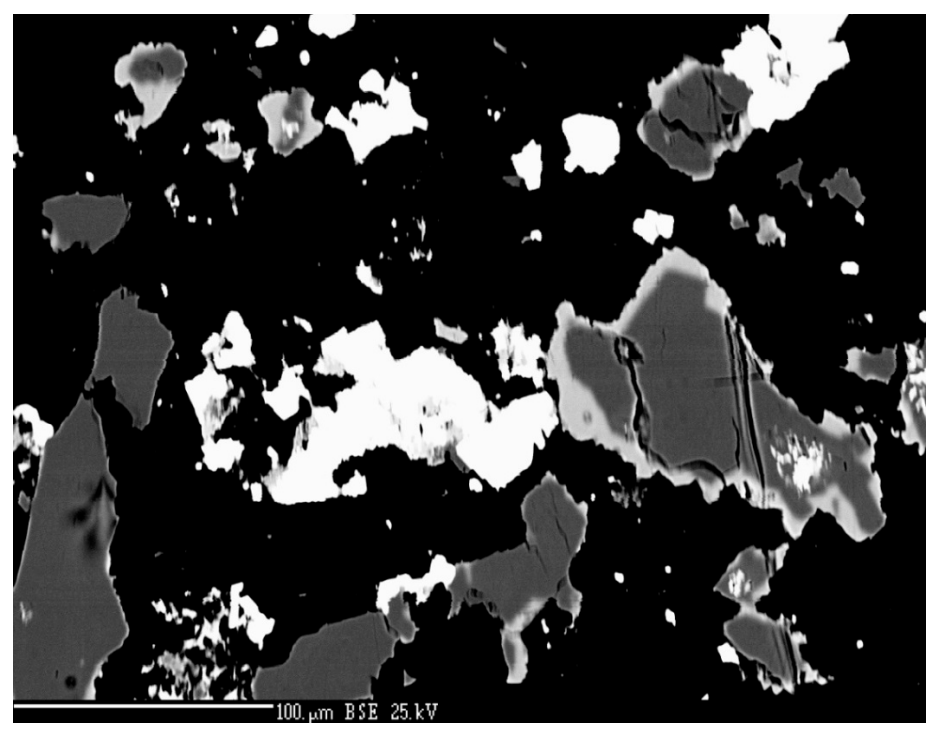

Figure 59. Zn-tetrahedrite aggregates (middle grey) overgrowing anhedral chalcocite (dark grey) in association with clausthalite (white). BSE photo. Příbram, a dump of shaft 16 . Photo by J. Sejkora and P. Škácha.

Two types of tetrahedrite were encountered in the course of the study of the chemical composition: Zn-tetrahedrite and Fe-tetrahedrite. Fe-tetrahedrite was observed in the association with antimonselite, Se-chalcostibite, Fe-tennantite, luzonite, chalcopyrite, or with chaméanite, bytízite, příbramite, giraudite, bukovite, crookesite, new As-Cu selenide, Fe-hakite, and chalcopyrite. Zn-tetrahedrite occurs as rims around chalcocite euhedral grains with clausthalite, in association with antimonselite, přibramite, new Hg-Cu-Sb selenide, tiemannite, and other minerals. Tetrahedrite in Přibram forms a continuous solid solution series with hakite (Figure 60) as previously reported by, e.g., Förster and Rhede [19] and Förster et al. [21]. 


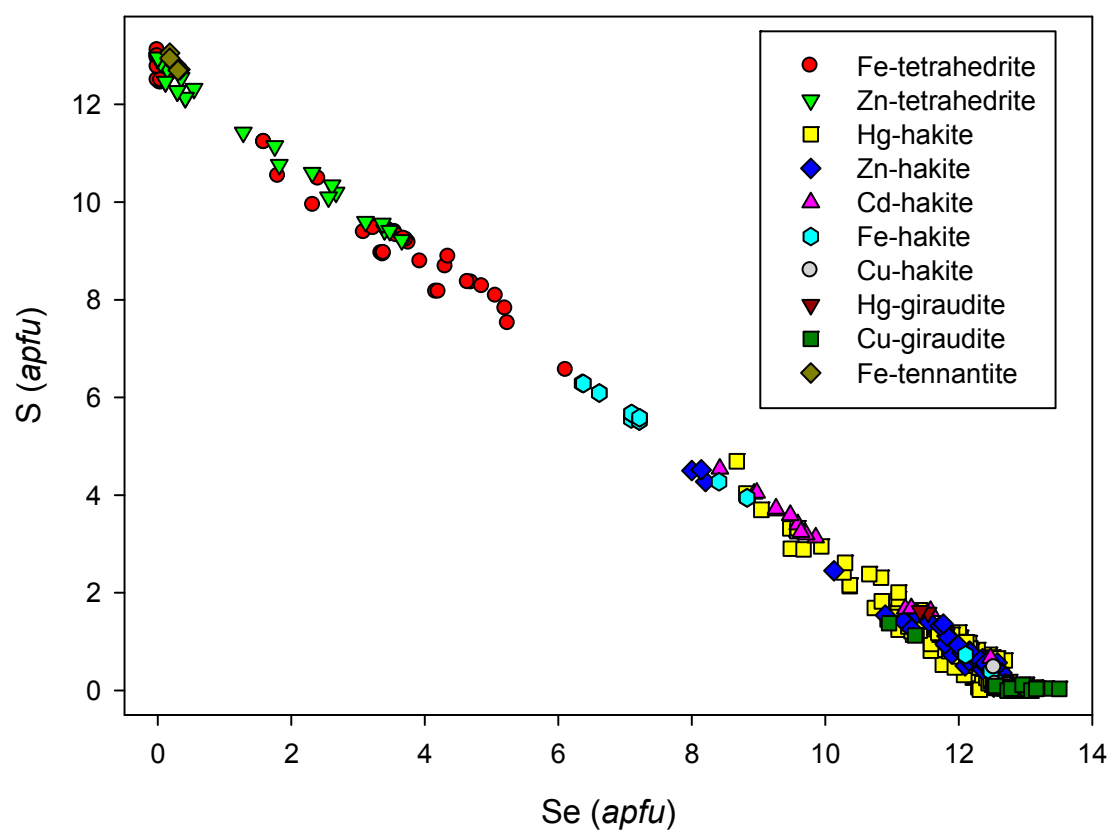

Figure 60. Se vs. S (apfu) graph for tetrahedrite group of minerals from Přibram.

The $A$ and $B$ positions of the crystal structure in $\mathbf{Z n - t e t r a h e d r i t e ~ a r e ~ d o m i n a n t l y ~ o c c u p i e d ~ b y ~}$ $\mathrm{Cu}$, but low Ag contents below 0.03 apfu occur in the $A$ position (Table S39). The dominant $\mathrm{Zn}$ (0.97-1.81 apfu) is accompanied by Fe (0.06-0.99 apfu), $\mathrm{Cu}$ (up to 0.24 apfu), $\mathrm{Hg}$ (up to 0.32 apfu), $\mathrm{Cd}$ (up to $0.32 a p f u$ ), and $\mathrm{Pb}$ (up to $0.17 \mathrm{apfu}$ ) in the $C$ position. In the $X$ position is the dominant $\mathrm{Sb}$, replaced in part by As in the range of 0.02-1.32 apfu. Sulphur is partly substituted by selenium (up to $4.27 \mathrm{apfu}$ ). The empirical formula of Zn-tetrahedrite (the mean of 15 analyses) on the basis of 29 apfu is $\left(\mathrm{Cu}_{5.99} \mathrm{Ag}_{0.01}\right)_{\Sigma 6.00} \mathrm{Cu}_{4.00}\left(\mathrm{Zn}_{1.42} \mathrm{Fe}_{0.45} \mathrm{Cd}_{0.02} \mathrm{Hg}_{0.07} \mathrm{~Pb}_{0.02}\right)_{\Sigma 1.98}\left(\mathrm{Sb}_{3.91} \mathrm{As}_{0.11}\right)_{\Sigma 4.01}\left(\mathrm{~S}_{11.51} \mathrm{Se}_{1.40}\right)_{\Sigma 12.91}$.

The $A$ and $B$ positions in Fe-tetrahedrite are-like in $\mathrm{Zn}$-tetrahedrite-occupied dominantly by $\mathrm{Cu}$ (Table S40), and $\mathrm{Ag}$ in the $A$ position is below 0.03 apfu. The $C$ position contains-in addition to the dominant $\mathrm{Fe}$ (up to 2.35 apfu) - $\mathrm{Zn}(0.01-1.12$ apfu), $\mathrm{Pb}$ (up to 0.16 apfu), $\mathrm{Cd}$ (up to 0.10 apfu), $\mathrm{Cu}$ (up to $0.73 \mathrm{apfu}$ ), and $\mathrm{Hg}$ (up to $0.14 \mathrm{apfu}$ ). Antimony is slightly substituted by As (up to 0.59 apfu) and S by Se (up to $5.21 \mathrm{apfu}$ ). The empirical formula of Fe-tetrahedrite (the mean of 27 analyses) on the basis of 29 apfu is $\left(\mathrm{Cu}_{5.99} \mathrm{Ag}_{0.01}\right)_{\Sigma 6.00} \mathrm{Cu}_{4.00}\left(\mathrm{Fe}_{1.22} \mathrm{Zn}_{0.32} \mathrm{Cu}_{0.47} \mathrm{~Pb}_{0.02} \mathrm{Hg}_{0.01}\right)_{\Sigma 2.04}\left(\mathrm{Sb}_{3.69} \mathrm{As}_{0.37}\right)_{\Sigma 4.06}\left(\mathrm{~S}_{9.74} \mathrm{Se}_{3.16}\right)_{\Sigma 12.90}$.

Tetrahedrite is a very abundant and characteristic mineral, especially in the neighboring Březové Hory base-metal district [100]. Its occurrences in the uranium district are most frequently tied to the base-metal mineralization of the siderite-sulphide stage. In the calcite-sulphidic stage, it belongs to locally-common minerals, often associated with chalcopyrite.

\subsubsection{Unnamed $\mathrm{Hg}-\mathrm{Cu}-\mathrm{Sb}$ Selenide from the Tetrahedrite Group}

A probable new $\mathrm{Hg}$-Cu-Sb selenide was discovered in a single sample with dzharkenite, ferroselite, příbramite, antimonselite, and Hg-hakite (Figure 61). This phase contains up to $30.73 \mathrm{wt} \% \mathrm{Hg}$ (Table S41). A similar phase was already described as an unnamed mineral with a proposed formula $(\mathrm{Cu}, \mathrm{Hg})_{1-x} \mathrm{Sb}_{\mathrm{x}}(\mathrm{Se}, \mathrm{S})$, from Guizhou Province, China, by Chen et al. [95]. 


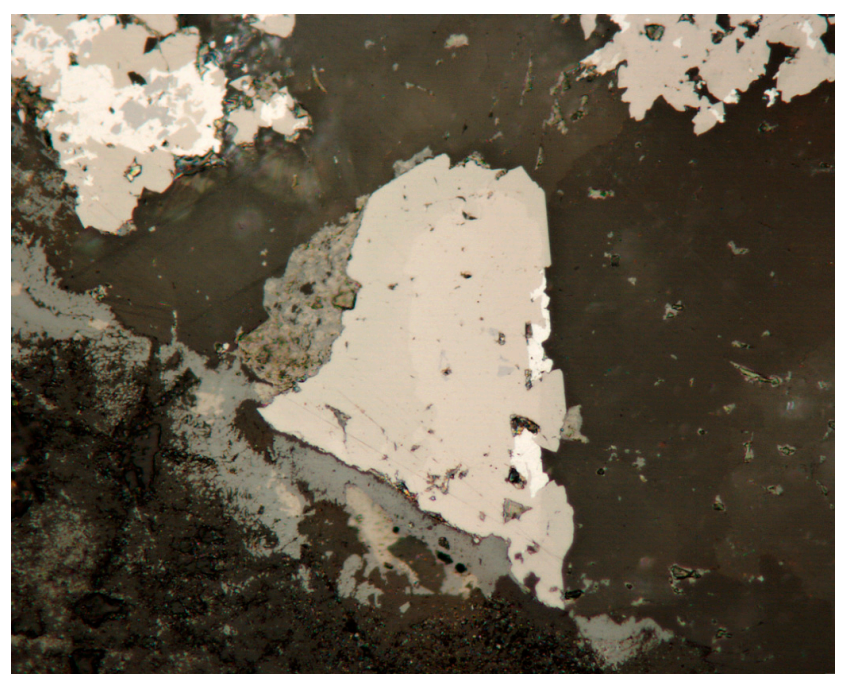

Figure 61. The core of the zonal aggregate is formed by new $\mathrm{Hg}$-Cu-Sb selenide and Hg-hakite (indistinguishable from each other in the ore microscope); the rim is grey tetrahedrite. Bluish-grey uraninite and white anhedral grains of tiemannite are the oldest phases in the association. Reflected light, one polarizer. FOV $210 \mu \mathrm{m}$. Přibram, a dump of shaft 16. Photo by P. Škácha.

The unnamed $\mathrm{Hg}-\mathrm{Cu}-\mathrm{Sb}$ selenide in the studied material from Příbram forms idiomorphic to hypidiomorphic grains up to $40 \times 20 \mu \mathrm{m}$ in size. In the BSE image, it is lighter than the associated hakite. A crystallization sequence tiemannite $\rightarrow$ unnamed $\mathrm{Hg}$-Cu-Sb selenide $\rightarrow \mathrm{Hg}$-hakite $\rightarrow$ tetrahedrite is quite distinct in one grain (Figure 62). In reflected light, no differences were noted between Hg-hakite and the unnamed phase; both are isotropic with a light brown color. The analogous unnamed selenide from China [95] is isotropic with a white color and yellowish tint.

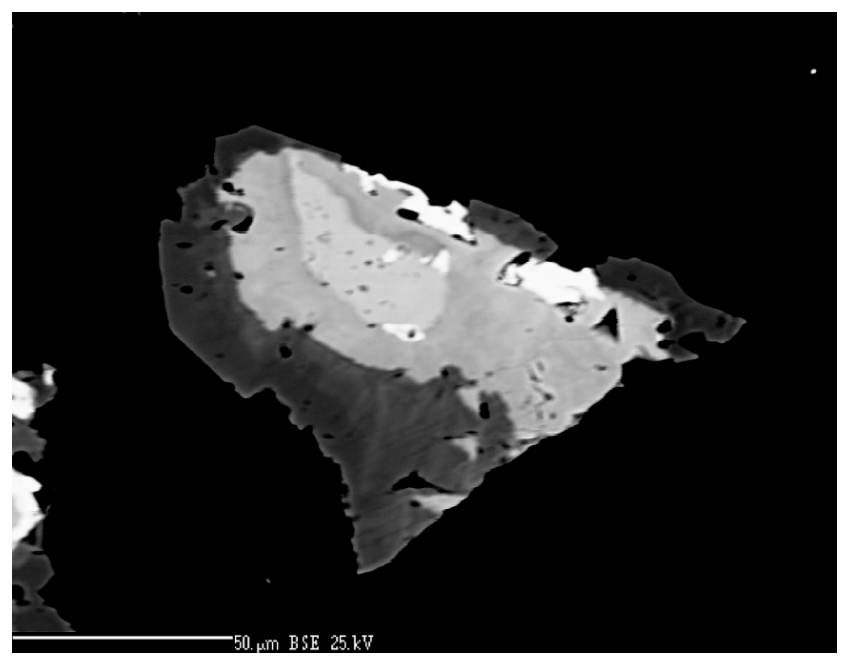

Figure 62. The core of the zonal aggregate is formed by new $\mathrm{Hg}-\mathrm{Cu}-\mathrm{Sb}$ selenide (light grey), overgrown by Hg-hakite (grey) with the tetrahedrite (dark grey) rim. Tiemannite (white) in the form of anhedral grains is the oldest phase in the association. BSE photo. Přibram, a dump of shaft 16. Photo by J. Sejkora and P. Škácha.

The relation of the crystal structure of the unnamed $\mathrm{Hg}$-Cu-Sb selenide from Př́bram to minerals of the tetrahedrite group was checked with EBSD, Raman spectroscopy, and single-crystal diffraction. A zoned aggregate of this mineral overgrown by $\mathrm{Hg}$-hakite and tetrahedrite was selected for the EBSD study. The fit of all three sets of EBSD data in the studied aggregate not only supports them having 
the tetrahedrite type (Figure 63), but also the identical crystallographic orientation of all three phases. Raman spectra were very similar for the unnamed selenide and coexisting Hg-hakite (Figure 64a), the main differences being a band at $261 \mathrm{~cm}^{-1}$ which was observed only for hakite, strong splitting of the stretching modes at $210-230 \mathrm{~cm}^{-1}$, and a shift to a lower wavenumber of the lattice modes near $70 \mathrm{~cm}^{-1}$ for the unnamed selenide. Bands were assigned based on the data of Kharbish et al. [101]. Hooke's Law [102] predicts significant shifts to lower wavenumbers for Sb-Se vibrations relative to $\mathrm{Sb}-\mathrm{S}$; this can be seen if the spectra of Figure 64A,B are compared. An analogous shift has been reported as a consequence of S-Se substitution in permingeatite-famatinite/luzonite [52]. Single-crystal X-ray diffraction experiments proved that the studied extracted grains of the unnamed $\mathrm{Hg}-\mathrm{Cu}$-Sb selenide are cubic, with a $=10.9636(12) \AA$ and $\mathrm{V}=1317.83(8) \mathrm{A}^{3}, \mathrm{Z}=2$.
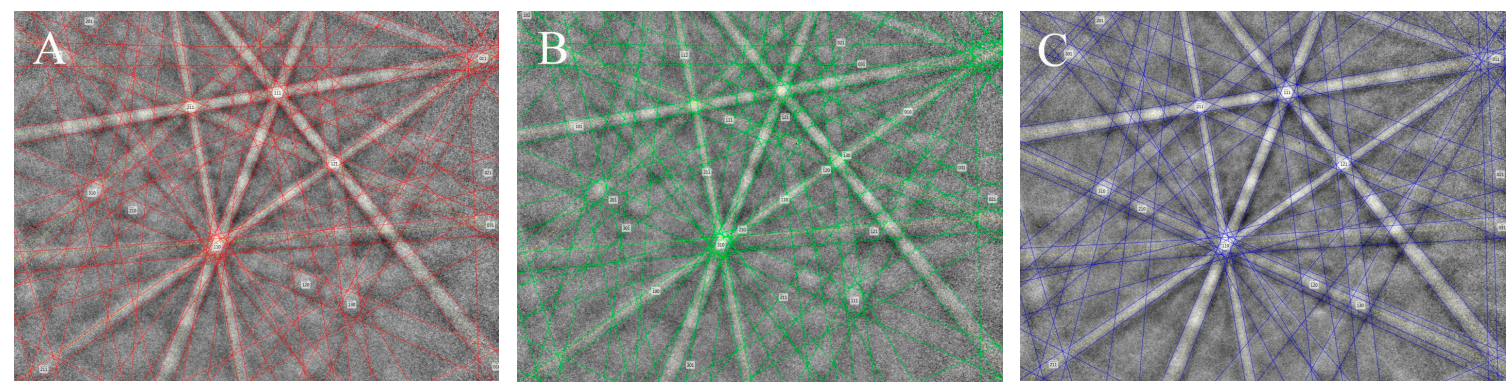

Figure 63. EBSD images of (A) new $\mathrm{Hg}$-Cu-Sb selenide, (B) Hg-hakite, and (C) tetrahedrite from Př́bram with indexed Kikuchi bands. These photos were taken from the zonal aggregate depicted in Figure 62. Photo by M. Racek.

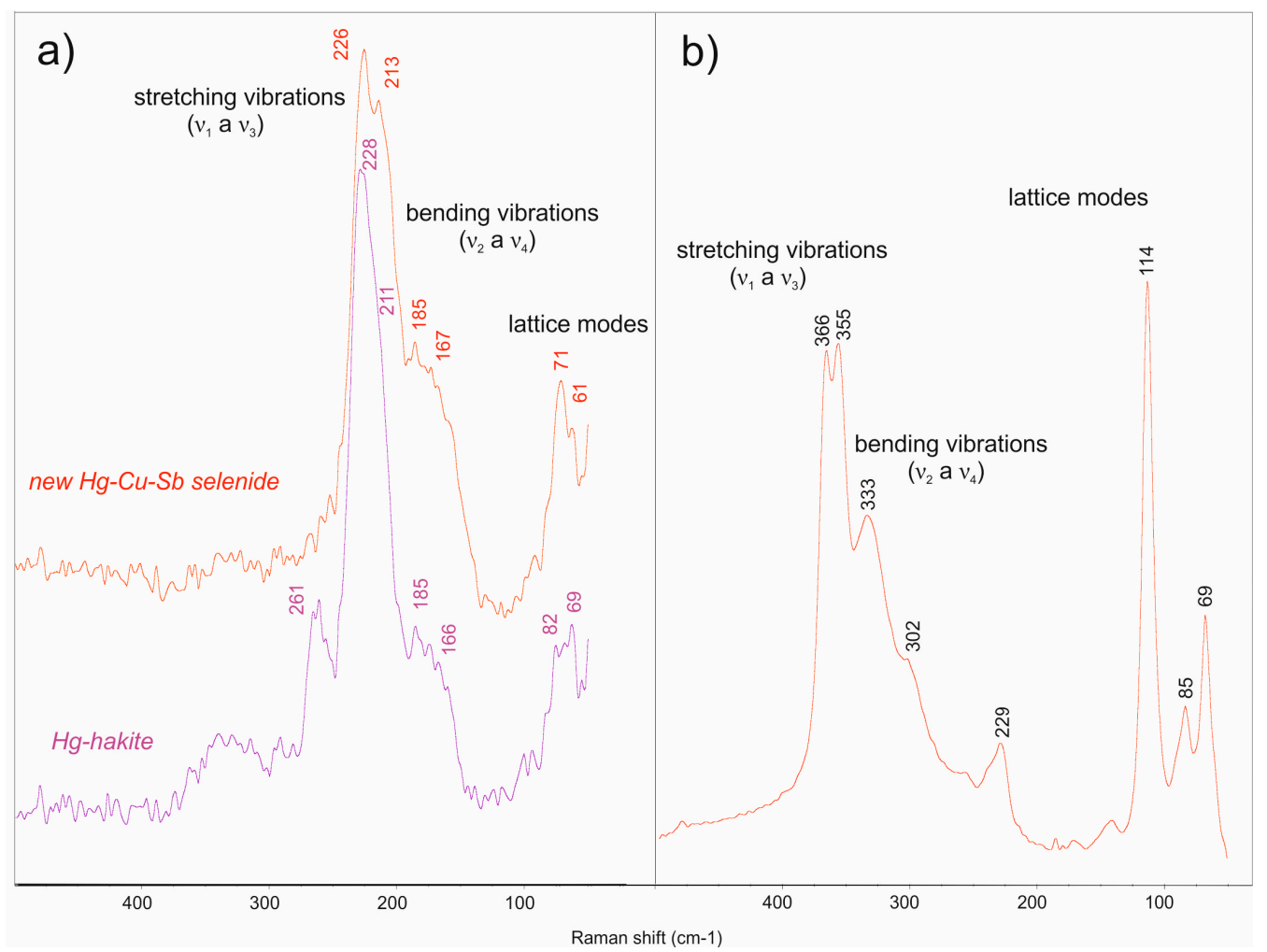

Figure 64. Raman spectra of (a) the new Hg-Cu-Sb selenide and Hg-hakite and (b) coexisting tetrahedrite. The vertical shift of spectra was done for clarity.

The interpretation of chemical composition of an unnamed $\mathrm{Hg}-\mathrm{Cu}-\mathrm{Sb}$ selenide is somewhat complicated; observed stoichiometry (especially low $\mathrm{Cu}$ content) indicates a presence of vacancies 
at the $A$ or $B-C$ positions. That is why the composition of this phase was calculated on the basis $(\mathrm{Sb}+\mathrm{As})=4 a p f u$. In the $A$ position of unnamed $\mathrm{Hg}$-Cu-Sb selenide from Prribram, minor Ag (0.18-0.34 apfu) and occasionally $\mathrm{Tl}$ contents (up to $0.05 \mathrm{apfu}$ ) were found. The range of $\mathrm{AgCu}_{-1}$ substitution of the unnamed phase is distinctly lower than in the case of coexisting Hg-hakite (Figure 65). Copper at the $A$ and $B$ positions (4.79-7.17 $\mathrm{Cu}$ apfu) is partly substituted by $\mathrm{Hg}$ (Figure 66). In the available literature for minerals of the tetrahedrite group sensus stricto, including synthetic phases (e.g. [103-108]), $\mathrm{Hg}$ contents above 2 apfu connected with substitution $\mathrm{Hg}^{2+}-\mathrm{Cu}^{1+}$ were not observed, including tetrahedrites from $\mathrm{Hg}$ deposits [100]. On the other hand, the $\mathrm{Hg}^{2+}-\mathrm{Cu}^{1+}$ substitution was observed in some minerals structurally related to tetrahedrite (e.g., galkhaite, aktashite) [109], or related to polybasite-fettelite [110]. The observed Hg contents (2.73-4.09 apfu) positively correlate (Figure 67) with calculated vacancies (1.73-3.06 pfu); the presence of vacancies also provides a charge balance to the formula. In contrast to coexisting Hg-hakite, the contents of $\mathrm{Zn}$ (up to 0.14 apfu), Fe (up to $0.12 \mathrm{apfu}$ ), and Cd (up to $0.10 \mathrm{apfu}$ ) in the unnamed phase are significantly lower (Figure 68). In the $X$ position, $\mathrm{Sb}$ is slightly substituted by As in the range 0.12-0.28 apfu. The determined range of $\mathrm{S}_{-} \mathrm{Se}_{-1}$ substitution in the unnamed $\mathrm{Hg}-\mathrm{Cu}-\mathrm{Sb}$ selenide is distinctly more limited (0.67-2.02 S) than in the coexisting Hg-hakite (Figure 69).

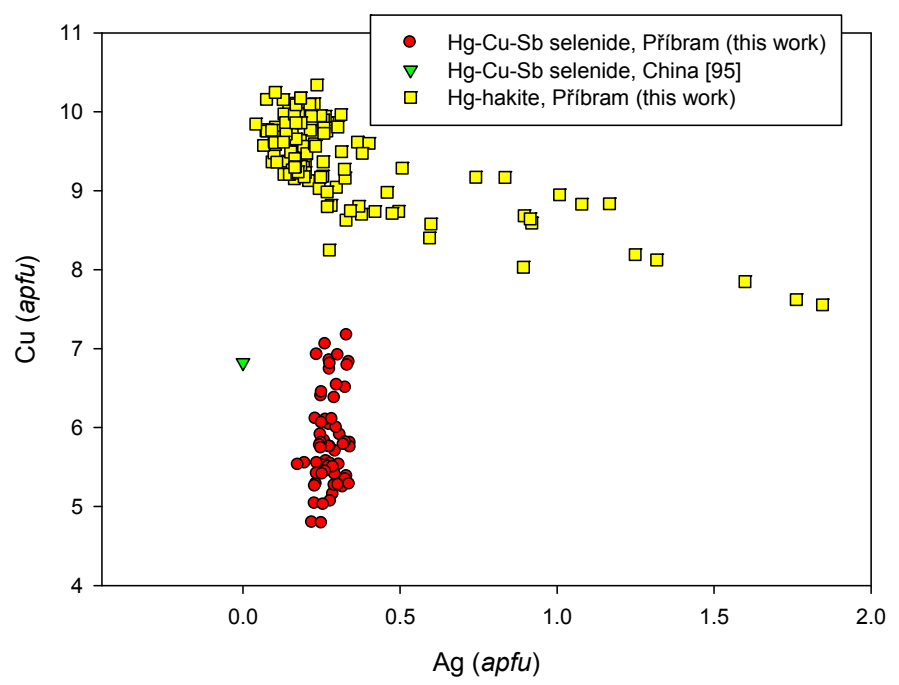

Figure 65. Ag vs. Cu (apfu) graph for unnamed $\mathrm{Hg}$-Cu-Sb selenide and Hg-hakite.

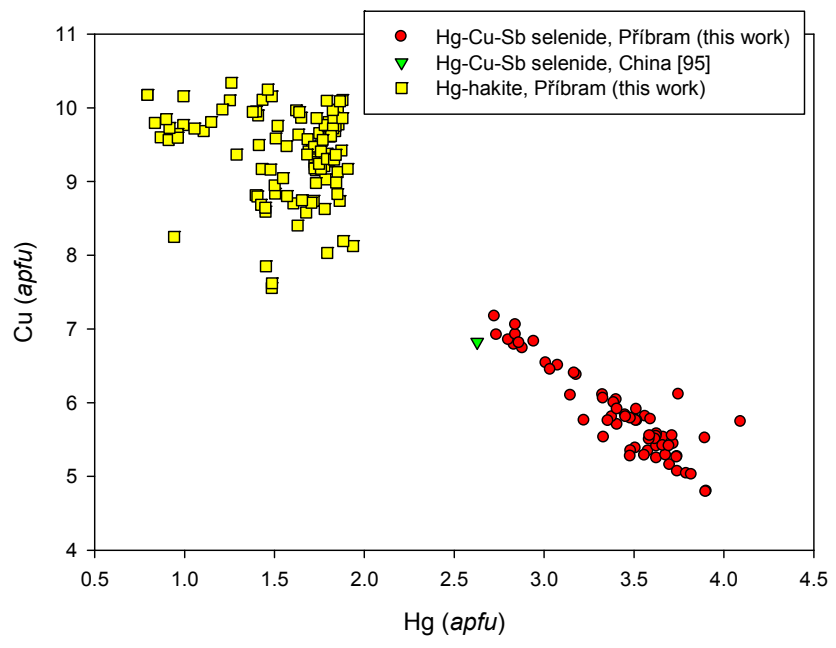

Figure 66. $\mathrm{Hg}$ vs. $\mathrm{Cu}(a p f u)$ graph for unnamed $\mathrm{Hg}$-Cu-Sb selenide and Hg-hakite. 


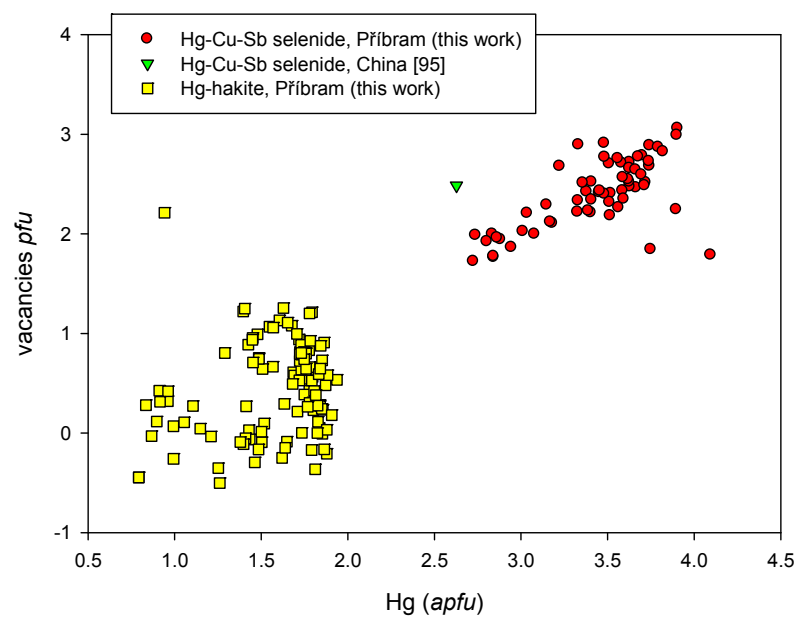

Figure 67. $\mathrm{Hg}(a p f u)$ vs. vacancies pfu graph for unnamed $\mathrm{Hg}$-Cu-Sb selenide and Hg-hakite; vacancies were calculated as $12-\left(\mathrm{Cu}^{+} \mathrm{Ag}^{+} \mathrm{Tl}^{+} \mathrm{Hg}^{+} \mathrm{Fe}^{+} \mathrm{Zn}^{+} \mathrm{Cd}\right)$.

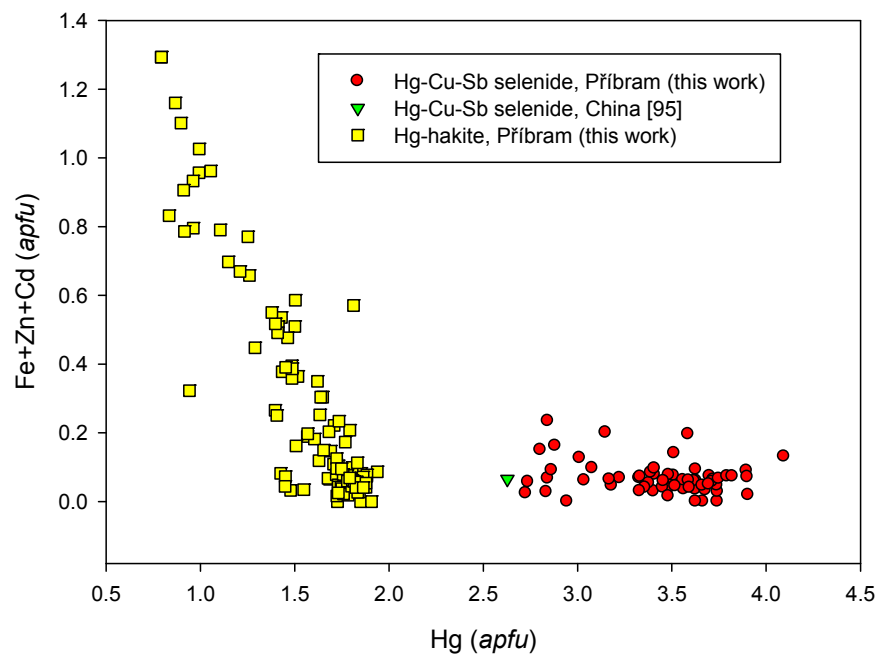

Figure 68. $\mathrm{Hg}$ vs. $\mathrm{Fe}+\mathrm{Zn}+\mathrm{Cd}(a p f u)$ graph for unnamed $\mathrm{Hg}-\mathrm{Cu}-\mathrm{Sb}$ selenide and $\mathrm{Hg}$-hakite.

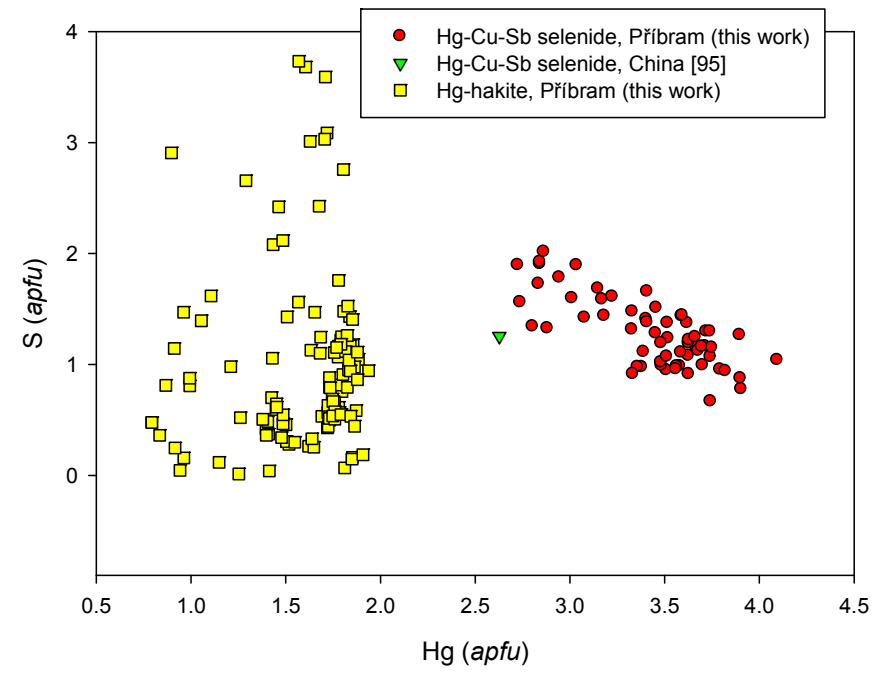

Figure 69. Hg vs. S (apfu) graph for unnamed $\mathrm{Hg}-\mathrm{Cu}-\mathrm{Sb}$ selenide and Hg-hakite. 
The empirical formula of a new Hg-Cu-Sb selenide (mean of 62 analyses) on the basis of $(\mathrm{Sb}+\mathrm{As})=4$ apfu is $\mathrm{Cu}_{5.83} \mathrm{Ag}_{0.28} \square_{2.40} \mathrm{Hg}_{3.43} \mathrm{Fe}_{0.01} \mathrm{Zn}_{0.03}\left(\mathrm{Sb}_{3.88} \mathrm{As}_{0.12}\right)_{\Sigma 4.00}\left(\mathrm{Se}_{10.83} \mathrm{~S}_{1.29}\right)_{\Sigma 12.12}$ and the expected ideal formula is $\mathrm{Cu}_{6} \mathrm{Hg}_{4} \mathrm{Sb}_{4} \mathrm{Se}_{13}$.

\subsubsection{Trends in the Chemical Composition of Minerals of the Tetrahedrite Group at Přibram}

Minerals of the tetrahedrite group viewed from the perspective of element substitution represent some of the most complex phases. The complex compositional variations in S-dominant members of the tetrahedrite group have been studied by numerous authors (cf. [100,103,105-108]), and particularly by Velebil et al. [100]. In contrast, information on possible substitutions in Se-dominant members is rather limited. Papers by numerous authors $[11,15,19,39,111-114]$ present related information.

In the frame of the study of minerals of the tetrahedrite group from Přibram were data obtained for co-existing Se- and S-dominant members of this group. Increased Ag contents (1-2 apfu) in the A position were observed only in Hg-hakite; analysed contents in all remaining members of this group do not exceed 0.5-0.7 apfu (Figure 56). Ag content is lower in the case of tetrahedrite; conversely, Ag content is higher in hakite-especially in Hg-hakite (Figure 70). In the $C$ position of tetrahedrite is a preference for $\mathrm{Zn}$ and $\mathrm{Fe}$, in contrast to closely-associated hakite with a preference for $\mathrm{Hg}, \mathrm{Zn}$, and $\mathrm{Cd}$. A larger ionic radius of selenium atoms with respect to sulphur or the local geochemical conditions may be responsible for the situation. The rare undersubstitued Fe-tetrahedrite was found in association with selenides from Př́bram (Figure 71) [54]. The selenides contain larger voids in the structure, which may more easily host larger cations such as $\mathrm{Hg}$, $\mathrm{Ag}$, or $\mathrm{Cd}$. A change in fluid chemistry over the time span of crystallization can be an additional factor [54].

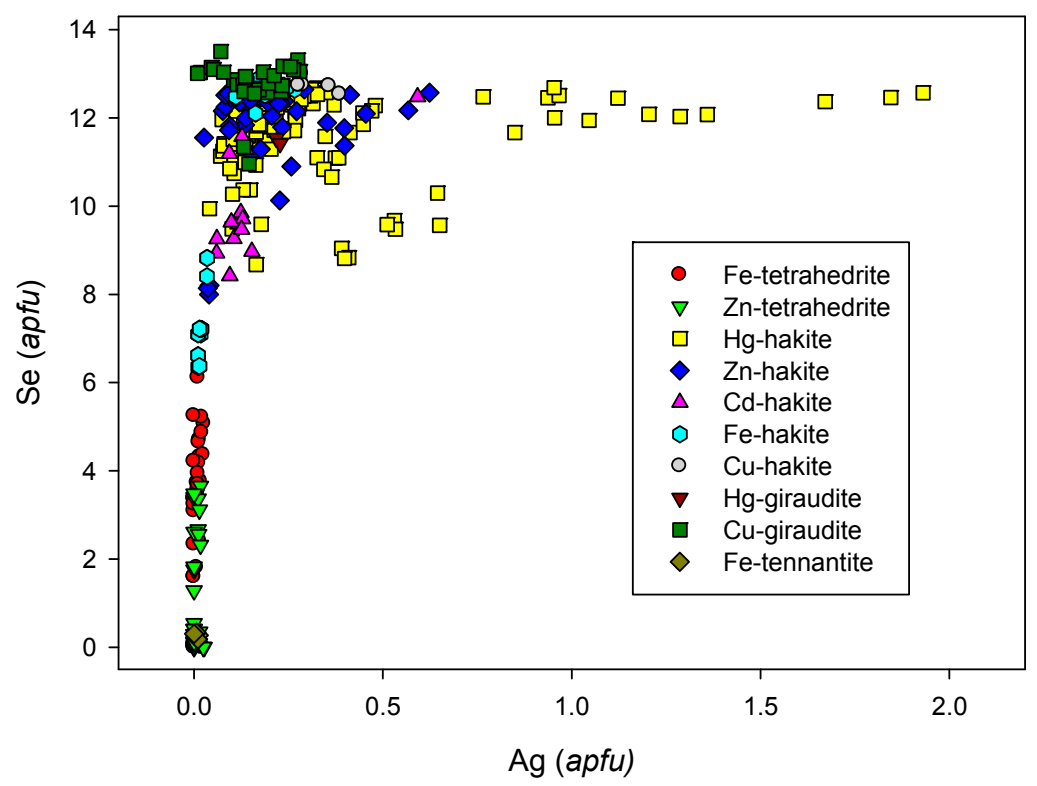

Figure 70. Ag vs. Se (apfu) graph for tetrahedrite group of minerals from Př́bram. 


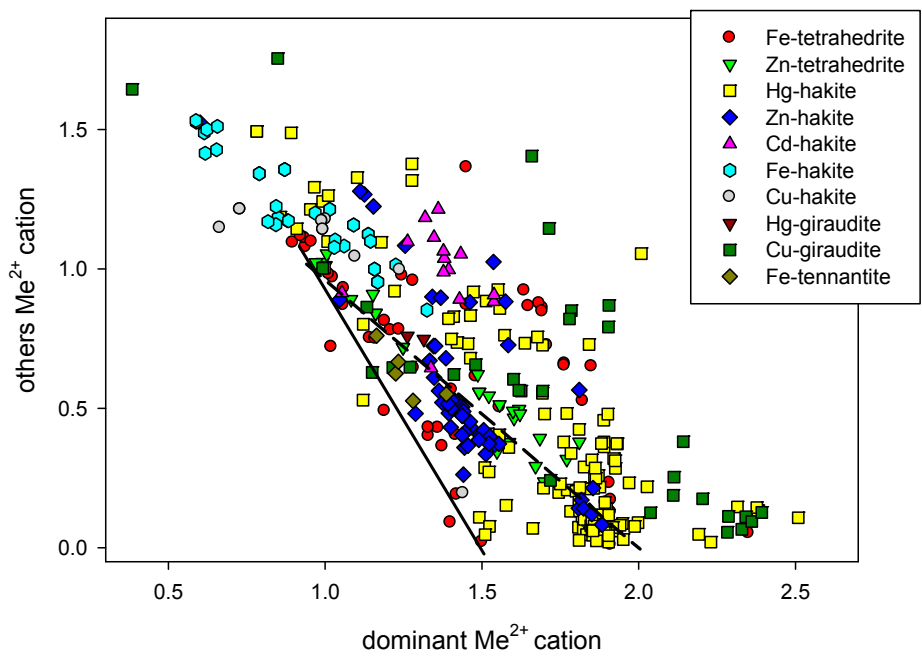

Figure 71. Dominant $\mathrm{Me}^{2+}$ cation vs. others $\mathrm{Me}^{2+}$ cations graph for the tetrahedrite group of minerals from Přibram. Most tetrahedrite-group members follow the 1:1 to 2:0 mixing-line for $\mathrm{Me}^{2+}$, except for the Se-rich Fe-tetrahedrite, which follows a line from the $1 \mathrm{Fe}: 1 \mathrm{Me}^{2+}$ ratio to the $1.5 \mathrm{Fe}: 0 \mathrm{Me}^{2+}$ ratio.

\subsubsection{Tiemannite, HgSe}

In the studied association, tiemannite is one of the relatively common minerals. It forms metallic grey anhedral grains up to $500 \mu \mathrm{m}$ across in calcite gangue and is accompanied by other selenides. Tiemannite is intergrown with brodtkorbite, eucairite, and minerals of the tetrahedrite group (Figure 72) or prríbramite. It is light grey in reflected light, and is isotropic.

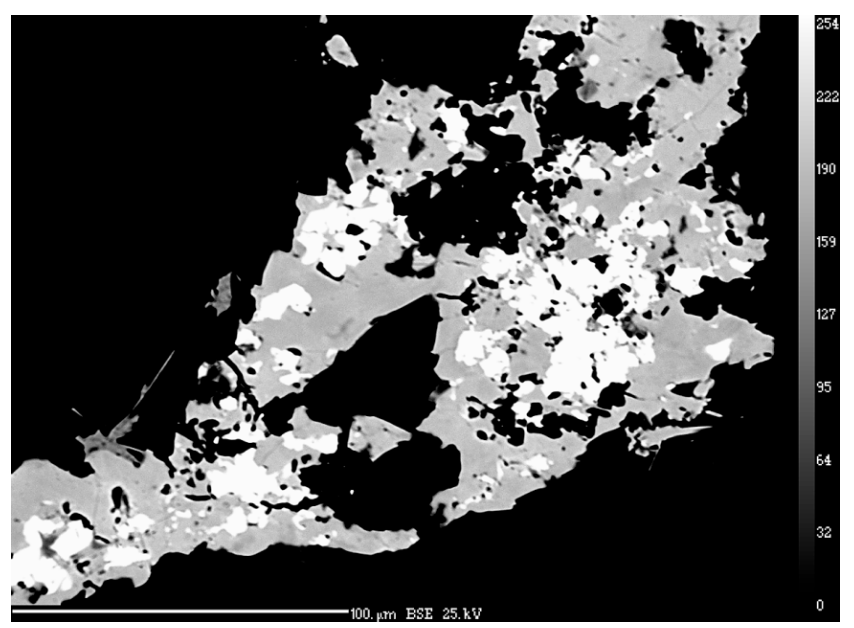

Figure 72. Hakite aggregates (grey) with abundant earlier grains of tiemannite (white); tiny acicular crystals of the youngest antimonselite (dark grey) are on the bottom-left of the figure. BSE photo. Přibram, a dump of the shaft 16 . Photo by J. Sejkora and P. Škácha.

The chemical composition of the studied tiemannite (Table S42) contains minor Ag (up to $0.03 \mathrm{apfu}$ ), $\mathrm{Cd}$ (up to $0.14 \mathrm{apfu}$ ), As (to $0.01 \mathrm{apfu}$ ), and $\mathrm{Cu}$ (to $0.05 \mathrm{apfu}$ ) in addition to the dominant $\mathrm{Hg}$. In the anion position, besides dominant Se, S (up to 0.02 apfu) occurs locally. Its empirical formula (based on 93 analyses) on the basis of 2 apfu is $\left(\mathrm{Hg}_{0.98} \mathrm{Cd}_{0.02} \mathrm{Cu}_{0.01}\right)_{\Sigma 1.01}\left(\mathrm{Se}_{0.98} \mathrm{~S}_{0.1}\right)_{\Sigma 0.99}$.

An anomalous Te-rich tiemannite was found in a single sample (Table S43). In addition to elevated Te contents (0.10-0.24 apfu), minor Cu contents (up to $0.12 a p f u$ ) were also observed. The empirical formula of studied Te-tiemannite (the average of 38 analyses) on the basis of 2 apfu is $\left(\mathrm{Hg}_{0.95} \mathrm{Cd}_{0.01} \mathrm{Cu}_{0.05}\right)_{\Sigma 1.01}\left(\mathrm{Se}_{0.79} \mathrm{Te}_{0.18}\right)_{\Sigma 0.97}$. 
Minor contents of $\mathrm{Cu}$ (up to $0.17 \mathrm{wt} \%$ ) and $\mathrm{Cd}$ (up to $0.15 \mathrm{wt} \%$ ) are reported for tiemannite from the Tumiñico deposit, Argentina [79]. The distinctly negative correlation of Se and Te (Figure 73) confirms the existence of at least a partial solid solution between isostructural tiemannite $(\mathrm{HgSe})$ and coloradoite (HgTe). No information on significant contents of Te in tiemannite was found in the literature.

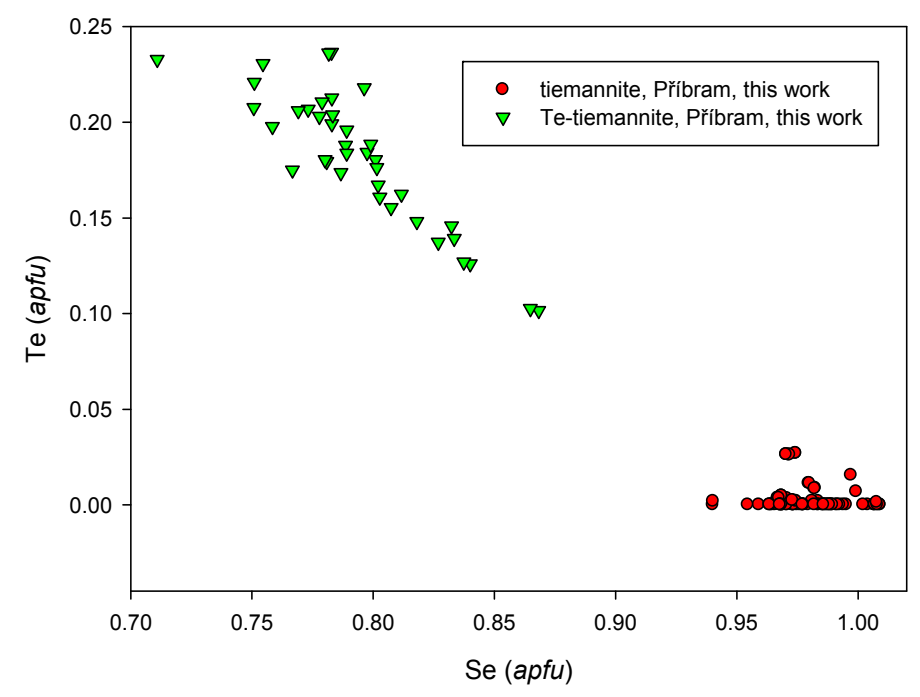

Figure 73. Se vs. Te (in $a p f u$ ) graph for tiemannite and Te-rich tiemannite from Příbram.

\subsubsection{Umangite, $\mathrm{Cu}_{3} \mathrm{Se}_{2}$}

In the studied samples, umangite is relatively abundant as minute anhedral aggregates with a typically violet color. The size of the aggregates is rarely up to $3 \mathrm{~mm}$. The mineral is frequently associated with berzelianite and eucairite, and less commonly with hakite, tiemannite, and brodtkorbite. S-rich umangite was found in association with chalcocite and S-rich berzelianite.

In reflected light, the mineral has a red-pink color (Figure 74); it is strongly anisotropic, with red-orange and yellow colors.
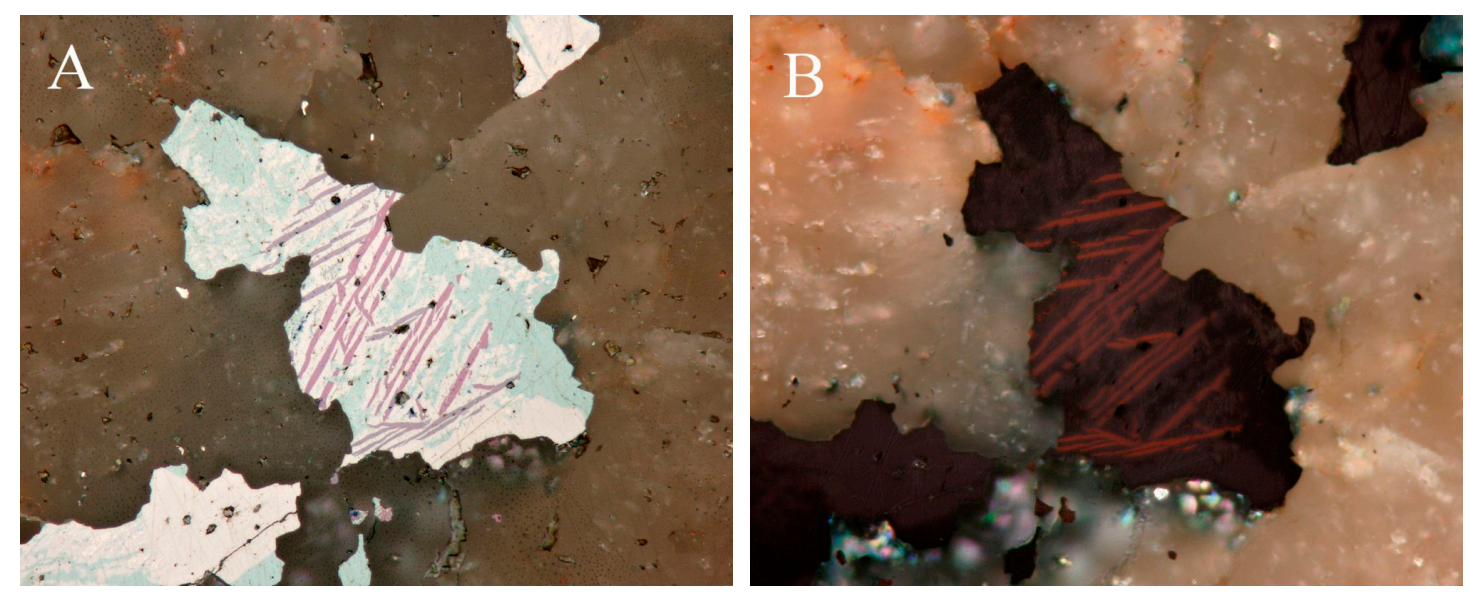

Figure 74. Lamellae of violet umangite replace bluish berzelianite. White eucairite is in the association. Reflected light, (A) one polarizer; (B) crossed polarizers. FOV $210 \mu \mathrm{m}$. Příbram, a dump of the shaft 16. Photo by P. Škácha.

The study of the chemical composition of umangite (Table S44) confirmed-in the cation position-minor contents of Ag (up to $0.28 \mathrm{apfu}$ ) and Fe (up to $0.20 \mathrm{apfu}$ ), in addition to the dominant 
$\mathrm{Cu}$. In the anion position, besides the dominant Se, there is some S (up to 0.36 apfu), and locally, Te (up to $0.01 \mathrm{apfu}$ ). The average empirical formula of the studied umangite from Přibram (the mean of 70 analyses) on the basis of $5 \mathrm{apfu}$ is $\left(\mathrm{Cu}_{3.00} \mathrm{Ag}_{0.02} \mathrm{Fe}_{0.02}\right)_{\Sigma 3.04}\left(\mathrm{Se}_{1.91} \mathrm{~S}_{0.05}\right)_{\Sigma 1.96}$.

One sample contained S-rich umangite (Table S45). The dominant selenium in the anion position (Se 1.18-1.45 apfu) is significantly substituted by S (0.61-0.85 apfu). Elevated sulphur contents in umangite (Figure 75) were reported from the Tilkerode uranium deposit, with values up to $13.5 \mathrm{wt} \%$ $\mathrm{S}$ by Wallis [115]. The chemical composition of S-rich umangite from Příbram (the mean of eight analyses) corresponds with the empirical formula $\left(\mathrm{Cu}_{2.83} \mathrm{Fe}_{0.14} \mathrm{Ag}_{0.01}\right)_{\Sigma 2.98}\left(\mathrm{Se}_{1.27} \mathrm{~S}_{0.75}\right)_{\Sigma 2.02}$. Te-rich umangite was found in the case of the only point analysed (Table S46). Its chemical composition is $\mathrm{Cu}_{2.98}\left(\mathrm{Se}_{1.86} \mathrm{Te}_{0.10} \mathrm{~S}_{0.06}\right)_{\Sigma 2.02}$.

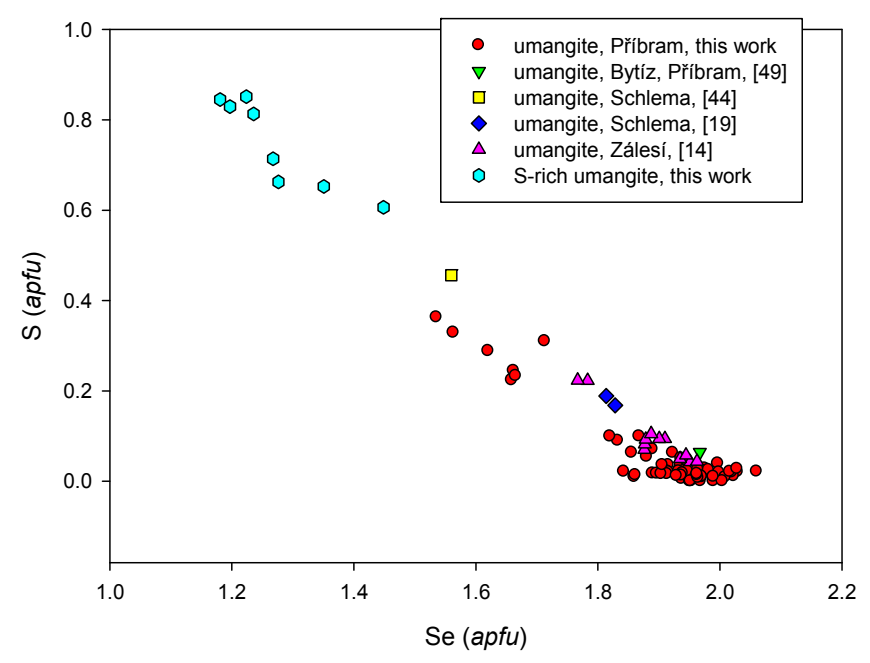

Figure 75. Se vs. S (apfu) graph for umangite from Příbram and other localities.

Umangite is a relatively abundant selenide in hydrothermal uranium deposits. It occurs in association with other $\mathrm{Cu}$ selenides. It is often formed via disintegration of berzelianite, which changes to umangite at temperatures below $112{ }^{\circ} \mathrm{C}$ [116]. Litochleb et al. [49] identified umangite in a historical sample from Bytíz. In addition to the major elements, it contains minor contents of $\mathrm{Pb}$ and $\mathrm{Hg}$.

\subsubsection{Unnamed Cu-As Selenide, CuAsSe}

Very tiny inclusions of an unnamed selenide with a maximum size of $15 \mu \mathrm{m}$, with chemistry corresponding to CuAsSe were found, showing extremely rare association with crookesite, chaméanite, giraudite, and other selenides (Figure 27).

It is grey in the reflected light, and anisotropy was not observed.

Except for the main elements, it contains a small amount of $\mathrm{Fe}, \mathrm{Ag}$, and $\mathrm{Tl}$ (up to $0.004 \mathrm{apfu}$ ). Only weak substitution $\mathrm{SSe}_{-1}$ (up to $0.013 \mathrm{apfu}$ ) and $\mathrm{SbAs}_{-1}$ (up to 0.003 apfu) was observed (Table S46). The chemical composition of unnamed Cu-As selenide from Přibram on the basis of 3 apfu (mean of two analyses) corresponds with the empirical formula $\mathrm{Cu}_{1.04} \mathrm{As}_{0.95}\left(\mathrm{Se}_{0.99} \mathrm{~S}_{0.01}\right)_{\Sigma 1.00}$.

Synthetic CuAsSe was explored by Whitfield [117]. Crystals of this phase have a structure with a simple polytypic relationship to the lautite (CuAsS) structure [118]. Both structures are ordered superstructures of the diamond arrangement, with $\mathrm{Cu}-\mathrm{As}$, As-(Se,Se), and $\mathrm{Cu}-(\mathrm{S}, \mathrm{Se})$ bonds.

\section{Succession of Crystallization}

In evaluating a succession of selenide mineralization in the studied ore district, it is important to note that all succession data were obtained from the dump material without knowing its original vein or its geological situation. The limited joint occurrence of some minerals, and mutual intergrowth relations, impose limits on the definition of a full succession. As all of the samples were collected at 
dumps, it is difficult to say if an unusual association (e.g., native arsenic, arsenolamprite, clausthalite, and berzelianite) represent certain evolutionary stages, or whether the minerals derived from a single vein-possibly affected by local lithology—are confined to a particular locality.

The presented scheme of mineral relations of the selenide and sulphide mineralization is based on a study of more than 250 polished sections. The possible or probable presence of some selenides or sulphides belonging to different generations (e.g., clausthalite, hakite, or chalcocite) would affect the accuracy of such a scheme. A general succession is proposed based on partial or local successions, but information is missing for some minerals of uncertain paragenetic position:

Eucairite, brodtkorbite, hessite $\rightarrow$ clausthalite $\rightarrow$ tiemannite $\rightarrow$ berzelianite $\rightarrow$ umangite $\rightarrow$ eskebornite $\rightarrow$ hakite, löllingite $\rightarrow$ giraudite, Se-tetrahedrite $\rightarrow$ tetrahedrite $\rightarrow$ Se-chalcopyrite $\rightarrow$ permingeatite, bytízite, př́bramite, Se-chalcostibite, luzonite, antimonselite.

\section{Discussion of the Formation Conditions}

The main part of the uraninite at this ore district formed in the course of the III. calcite-uraninite mineralization stage (5th-6th import stage) [59]. The same author classified selenides in the later calcite-sulphide stage corresponding to the 7th or 8th import stage. The relatively later age of selenides in relation to uraninite is in agreement with our observations. Other mineralization stages in the uranium district, and in the Březové Hory ore district, carry no selenide occurrences or sulphides with increased selenium content [119-121].

This situation follows from differences in Se and S properties and from specific conditions of the selenium mineralization. Similar to the situation at other deposits in the Czech Republic, selenides in the Přibram area formed at temperatures near $100{ }^{\circ} \mathrm{C}$. The abundance of calcite indicates a neutral to a weakly-alkaline environment $[122,123]$. Data on fluid inclusions in carbonates of the uraninite-antraxolite stage indicate crystallization temperatures of $80-140{ }^{\circ} \mathrm{C}$ [62]. The selenium thermometers confirm relatively low temperatures. Berzelianite-one of the most abundant selenides in the Přibram area-forms at temperatures exceeding $112{ }^{\circ} \mathrm{C}$, and it alters to umangite at lower temperatures. Both the minerals are relatively abundant in the studied samples. Very rare is bellidoite, which separates from berzelianite at temperatures lower than $123^{\circ} \mathrm{C}$. However, at higher selenium concentrations, berzelianite can coexist with bellidoite at still lower temperatures [124]. The local athabascaite occurrence indicates temperatures below $100{ }^{\circ} \mathrm{C}$ [68]. Similar data based on a study of selenide mineralization and fluid inclusions were obtained at the Tumiñico selenium deposit, Argentina, by Paar et al. [79].

The solutions involved in selenide precipitation were of low salinity, and partly of meteoritic origin [49,62]. A strong hematitic alteration is characteristic for the veins, although not evident in all samples.

The selenides in our samples crystallized before most of the sulphides of the same mineralization stage, in contrast to the observations of Litochleb et al. [49].

Selenides of the vein hydrothermal deposits formed under conditions of $f_{\mathrm{O} 2}$ above the hematite-magnetite buffer, probably in the range of $5.8 \mathrm{log}$ units (hematite-ferroselite univariant reaction) to 7 log units (anglesite-galena buffer), above the hematite-magnetite buffer [125]. Such high oxygen fugacity values result in geochemical separation of selenium from sulphur in the hydrothermal fluids, a high $\mathrm{Se}_{2} / \mathrm{S}_{2}$ fugacity ratio, and in the deposition of various selenide minerals. The deposition of the various selenide minerals, as well as the extent and nature of the association formed depend on the concentration of available Se in solution [124].

The mineralogy of the selenide association changed through the paragenetic sequence as a function of the changing environmental conditions. The first ore mineral to crystallize was the first generation of chalcocite, accompanied by subordinate bornite. Next, colloform uraninite precipitated as spherical aggregates and vein fillings. Then, selenides crystallized, often replacing uraninite.

Clausthalite and berzelianite form an independent association with arsenic and arsenolamprite. The dominant role of arsenic in the oldest phases of Ag-rich associations is known from the neighboring 
shaft 21, Přibram-Háje [126]. The local crystallization of both arsenic polymorphs resulted in a lower As/Sb fugacity, and only a limited quantity of arsenic entered the selenide structure during the main period of their crystallization. With regard to the strongly-limited association of both arsenic polymorphs with selenides, it is not possible to determine their relative age in relation to the main stage of selenide crystallization.

The large volume of precipitated selenides is evidence of a high $\mathrm{Se}_{2} / \mathrm{S}_{2}$ fugacity ratio. During the earlier part of the selenide crystallization stage, tiemannite, clausthalite, eucairite, and Cu selenides precipitated, while minerals of the tetrahedrite group formed later. The presence of $\mathrm{Cu}$ or $\mathrm{Cu}-\mathrm{Sb}$ in selenides from Přibram is typical. Crystallization of these minerals lowered the Se fugacity sufficiently to cause the transition into the calcite-sulphidic crystallization stage, with the formation of minerals such as tetrahedrite and chalcopyrite. Similar relations were also observed at the Tumiñico locality [79].

During the later phase of selenide mineralization, there is evidence of repeated partial dissolution of older selenides, with replacement by the youngest Se-bearing phases and the production of significant textural complexity. This stage features considerable mineralogical complexity, even if it is of a limited occurrence. Variation in S and Se contents or other elements at the micrometer scale indicates highly variable fugacities in time and space of the respective low-temperature processes. Antimonselite, permingeatite, Se-rich chalcostibite, part of hakite, and two new minerals for the mineral system-přibramite [46] and bytízite [47]—-belong to minerals of this regeneration stage of mineralization in particular. Rare As-dominant selenides and sulphides-in contrast to local common native arsenic occurrence-are concentrated in this later phase. Arsenic was probably supplied by hydrothermally-altered older minerals.

The variability of selenium minerals of the calcite-sulphidic stage derives primarily from a compositional variation of hydrothermal fluids supplying elements for selenide crystallization. Variation in Se/S fugacity contributed to the occurrence of sulphide and selenide pairs, such as Se-chalcostibite-přibramite, chalcopyrite-eskebornite, hakite-tetrahedrite, giraudite-tennantite, and others. Selenides containing $\mathrm{Cd}$ and $\mathrm{Tl}$ are very rare. Minerals containing increased concentrations of these elements were not found, with the exception of $\mathrm{Cd}$ substitution in sphalerite in the Přibram ore district.

The selenide mineralization in the Přibram uranium district shows variations in $\mathrm{Se}_{2}$ and $\mathrm{S}_{2}$ fugacities ( -12 to -18 in the case of Se, and -17 to -24 of $S$, respectively), which are similar to those published in detail by Simon et al. [125] for "selenide-bearing nonconformity-related uranium deposits". Considering the absence of krut'aite in the association and according to the stability field diagram for the temperature $100{ }^{\circ} \mathrm{C}$ [125], we can expect the origin of the selenium mineralization under the krut'aite stability field. This corresponds to a $\log \mathrm{fSe}_{2}$ lower than -12 .

A characteristic feature of selenide association in the Přibram uranium district is the fine-grained character of this mineralization. The individual selenide grains rarely exceed the limit of $2 \mathrm{~mm}$. The occurrences include particularly abundant selenides of $\mathrm{Cu}, \mathrm{Sb}$, and $\mathrm{Hg}$. In contrast, no selenides of $\mathrm{Co}$, $\mathrm{Ni}, \mathrm{Bi}, \mathrm{Au}$, and other elements have been found, although these occur at the Předbořice deposit, not far from the Přibram area. The presence of minute and rare inclusions of hessite is surprising. The origin of tellurium contained in this mineral is unlikely in hydrothermal alterations of an older gold-bearing quartz gangue, which typically contains tellurides. However, characteristic quartz gangue was absent in veins carrying selenides.

Hessite in association with selenides is known from the Frederik VII mine in Southern Greenland [127]. In uranium deposits, it was found only at Niederschlema by Förster [17]. The accompanying selenides in Přibram-with the exception of tiemannite, and occasionally berzelianite and umangite-are free of notably-elevated Te, as at the Niederschlema deposit.

\section{Conclusions}

The Příbram uranium and base-metals district contains important occurrences of selenide mineralization. Twenty-six mineral species were identified, including two new approved minerals 
(příbramite and bytízite) and two possible new mineral species ( $\mathrm{Hg}$-Cu-Sb and $\mathrm{Cu}-\mathrm{As}$ selenide). The minerals were characterized by chemical and optical data, in some cases by powder or single-crystal X-ray diffraction. The detailed study confirmed the occurrence of several minerals which are rare on a worldwide scale (e.g., antimonselite, brodtkorbite, chaméanite, giraudite, cadmoselite, permingeatite), or a wide range of substitutions (especially of tetrahedrite-group minerals).

Crystallization of the selenides reflects a high $S_{2} / S_{2}$ fugacity ratio, but the phases formed changed through time as conditions evolved. Simple selenides of $\mathrm{Pb}, \mathrm{Hg}, \mathrm{Ag}$, and $\mathrm{Cu}$ formed first, with tetrahedrite-group minerals later, and finally, some very late minerals as replacements of earlier selenides. Micron-scale variation of S/Se ratios and contents of other elements reflect conditions that varied rapidly in time and space.

The origin of selenide mineralization in the Příbram uranium district occurred between the calcite-uraninite and carbonate-sulphidic stage. Selenides—always later than uraninite-crystallized at temperatures near $100{ }^{\circ} \mathrm{C}$ in a neutral-to-weakly-alkaline environment from solutions with high oxygen fugacity and a high $\mathrm{Se}_{2} / \mathrm{S}_{2}$ fugacity ratio.

Supplementary Materials: The following are available online at http://www.mdpi.com/2075-163X/7/6/91/s1.

Acknowledgments: The authors thank Ivo Macek (National Museum, Prague), Radek Škoda (Masaryk University, Brno), and Martin Racek (Charles University, Prague) for their kind cooperation with laboratory studies. The research was financially supported by project GA14-27006S of the Czech Science Foundation and by the Ministry of Culture of the Czech Republic (DKRVO 2017/01; National Museum 00023272) for PŠ and JS. Single-crystal X-ray diffraction experiments were conducted using instruments of the ASTRA lab established within the Operation program Prague Competitiveness project CZ.2.16/3.1.00/24510. Anonymous referees, as well as guest editor Hans-Jürgen Förster, and assistant editors Irwin Liang and Jingjing Yang are acknowledged for their comments and suggestions that helped greatly to improve the manuscript.

Author Contributions: Pavel Škácha found mineralogical samples. Pavel Škácha and Jiří Sejkora conducted the WDS and PXRD analyses and wrote the article. Jakub Plášil conducted the SXRD analyses and wrote related chapters.

Conflicts of Interest: The authors declare no conflict of interest.

\section{References}

1. Johan, Z. Preliminary report on the tiemannite-HgSe occurrence from Černý Důl in Krkonoše. Čas. Miner. Geol. 1960, 5, 65. (In Czech)

2. Kvaček, M.; Plhal, J.; Matuška, J.; Kupka, F. The berzelianite $\mathrm{Cu}_{2-\mathrm{x}}$ Se finding in Morava. Čas. Miner. Geol. 1963, 8, 267. (In Czech)

3. Kvaček, M. Selenides from the uranium deposits of western Moravia, Czechoslovakia-Part 1. Acta Univ. Carol. Geol. 1973, 1-2, 23-36.

4. Kvaček, M. Selenides from the uranium deposits of western Moravia, Czechoslovakia-Part 2. Acta Univ. Carol. Geol. 1979, 1-2, 15-38.

5. Blüml, A.; Tacl, A.; Rus, V. The occurrence of selenium minerals in southwest part of the selenides from the northwestern part of the Sedlčany-Krásná Hora metamorphosed island. Čas. Miner. Geol. 1964, 9, 73. (In Czech)

6. Blüml, A.; Tacl, A.; Rus, V. Selenides from the northwestern part of the Sedlčany-Krásná Hora metamorphosed island. Čas. Miner. Geol. 1966, 11, 37-45. (In Czech)

7. Johan, Z. Merenskyite, $\mathrm{Pd}(\mathrm{Te}, \mathrm{Se})_{2}$, and the low-temperature selenide association from the Předbořice uranium deposit, Czechoslovakia. Neues Jahrb. Mineral. Monatsh. 1989, 4, 179-191.

8. Čech, F.; Vavřín, I. Poubaite, $\mathrm{PbBi}_{2}(\mathrm{Se}, \mathrm{Te}, \mathrm{S})_{4}$, a new Miner. Neues Jahrb. Mineral. Monatsh. 1978, 9-19.

9. Čech, F.; Vavř́n, I. Součekite, $\mathrm{CuPbBi}(\mathrm{S}, \mathrm{Se})_{3}$, a new mineral of the bournonite group. Neues Jahrb. Mineral. Monatsh. 1979, 289-295.

10. Novická, Z.; Kašpar, P. The new finding of selenides in exocontact of the Middle Bohemian Pluton. Geol. Průzk. 1976, 18, 250.

11. Litochleb, J.; Šrein, V.; Novická, Z.; Šreinová, B. Selenides from the uranium deposit Ústaleč (nw. Bohemia). Bull. Mineral.-Petrol. Odd. Nár. Muz. 1999, 7, 98-108. (In Czech) 
12. Fojt, B.; Tenčík, I.; Panovský, K. Mineralogy and Geochemical Research of the Ore Deposits etc. Zálesí near Javorník Deposit; Lesní Čtvrt': Horní Hoštice, Bílá Voda, Czech Republic, Unpublished Report; 1971. (In Czech)

13. Topa, D.; Makovicky, E.; Sejkora, J.; Dittrich, H. The crystal structure of watkinsonite, $\mathrm{Cu}_{2} \mathrm{PbBi}_{4} \mathrm{Se}_{8}$, from the Zálesí uranium deposit, Czech Republic. Can. Mineral. 2010, 48, 1109-1118. [CrossRef]

14. Sejkora, J.; Plášil, J.; Litochleb, J.; Škácha, P.; Pavlíček, R. A selenide association with macroscopic umangite from the abandoned uranium deposit Zálesí, Rychlebské hory Mountains (Czech Republic). Bull. Mineral.-Petrol. Odd. Nár. Muz. 2012, 20, 187-196. (In Czech)

15. Sejkora, J.; Macek, I.; Škácha, P.; Pauliš, P.; Plášil, J.; Toegel, V. An occurrence of Hg and Tl selenides association at the abandoned uranium deposit Zálesí, Rychlebské hory Mountains (Czech Republic). Bull. Mineral.-Petrol. Odd. Nár. Muz. 2014, 22, 333-345. (In Czech)

16. Sejkora, J.; Škácha, P.; Kopecký, S.; Kopecký, S.; Pauliš, P.; Malíková, R.; Velebil, D. Se and Cu mineralization from Bílá Voda near Javorník (Czech Republic). Bull. Mineral.-Petrol. Odd. Nár. Muz. 2016, 24, 161-1177. (In Czech)

17. Förster, H.J. Mineralogy of the Niederschlema-Alberoda U-Se-polymetallic deposit, Erzgebirge, Germany. II. Hessite, $\mathrm{Ag}_{2} \mathrm{Te}$, and native Te (?), the first tellurium minerals. Neues Jahrb. Mineral. Abh. 2004, 180, 101-113. [CrossRef]

18. Förster, H.J. Mineralogy of the Niederschlema-Alberoda U-Se-polymetallic deposit, Erzgebirge, Germany. IV. Continuous solid solutions between clausthalite and galena. Neues Jahrb. Mineral. Abh. 2005, 181, 2, 125-134. [CrossRef] [PubMed]

19. Förster, H.J.; Rhede, D. Mineralogy of the Niederschlema-Alberoda U-Se-polymetallic deposit, Erzgebirge, Germany. III. First indication of complete miscibility between tennantite and giraudite. Can. Mineral. 2004, 42, 1719-1732. [CrossRef]

20. Förster, H.J.; Tischendorf, G. Se-rich tennantite and constraints on p-T-X conditions of selenide mineral formation in the Schlema-Alberoda uranium ore district (western Erzgebirge, Germany). Neues Jahrb. Mineral. Abh. 2001, 176, 109-126.

21. Förster, H.J.; Rhede, D.; Tischendorf, G. Continuous solid-solution between mercurian giraudite and hakite. Can. Mineral. 2002, 40, 1161-1170. [CrossRef]

22. Förster, H.J.; Rhede, D.; Tischendorf, G. Mineralogy of the Niederschlema-Alberoda U-Se-polymetallic deposit, Erzebirge, Germany. I. Jolliffeite, NiAsSe, the rare Se-dominant analogue of gersdorffite. Can. Mineral. 2004, 42, 841-849. [CrossRef]

23. Förster, H.J.; Tischendorf, G.; Rhede, D. Mineralogy of the Niederschlema-Alberoda U-Se-polymetallic deposit, Erzgebirge, Germany. V. Watkinsonite, nevskite, bohdanowiczite and other bismuth minerals. Can. Mineral. 2005, 43, 899-908. [CrossRef]

24. Sejkora, J.; Škácha, P.; Venclík, V.; Plášil, J. Vanadium-uranium mineralization in the Prachovice quarry (Czech Republic). Bull. Mineral.-Petrol. Odd. Nár. Muz. 2013, 21, 2, 113-130. (In Czech)

25. Sejkora, J.; Škácha, P. The occurrence of selenides at the deposit Běstvina, Železné hory Mountains (Czech Republic). Bull. Mineral.-Petrol. Odd. Nár. Muz. 2015, 23, 255-260. (In Czech)

26. Sejkora, J.; Škácha, P. Selenides from the fluorite deposit Moldava, Krušné hory Mountains (Czech Republic). Bull. Mineral.-Petrol. Odd. Nár. Muz. 2015, 23, 229-241. (In Czech)

27. Malec, J. Morphology and composition of gold from the alluvial sediments In Czech Republic. Bull. Mineral.-Petrol. Odd. Nár. Muz. 2002, 10, 156-166. (In Czech)

28. Pašava, J.; Sulovský, P.; Kovalová, M. Geochemistry and mineralogy of Proterozoic metal-rich black shales from the Bohemian Massif, Czech Republic, with a description of possible new molybdenum selenide and telluride phases. Can. Mineral. 1993, 31, 745-754.

29. Scharm, B.; Scharmová, M. Accessory minerals in proterozoic silicit rocks in Kokšín near Mítov. Bull. Mineral.-Petrol. Odd. Nár. Muz. 1997, 4-5, 113-120. (In Czech)

30. Scharmová, M. Mineralogical Evaluation of Wolframite Specimen from the Krupka-Barbora Adit; MS ČSUP: Stráž pod Ralskem, Česká Lípa, Czech Republic, 1989. (In Czech)

31. Sejkora, J. Mineralogical Association of the Burning Dump of the Kateřina Mine in Radvanice Near Trutnov and Processes of Their Origin. Ph.D. Thesis, Faculty of Science, Masaryk University, Brno, Czech Rebublic, 2002.

32. Johan, Z.; Kvaček, M. Bukovite, $\mathrm{Cu}_{3+\mathrm{x}} \mathrm{Tl}_{2} \mathrm{FeSe}_{4-\mathrm{x}}$, new Miner. Bull. Soc. Franç. Minéral. Cristallogr. 1971, 94, 529-533. (In French). 
33. Johan, Z.; Kvaček, M.; Picot, P. Sabatierite, new selenide of copper and thallium. Bull. Minéral. 1978, 101, 557-560. (In French).

34. Montreuil, L.A. Bellidoite: A new copper selenide. Econ. Geol. 1975, 70, 384-387. [CrossRef]

35. Banas, M.; Atkin, D.; Bowles, J.F.W.; Simpson, P.R. Definitive data on bohdanowiczite, a new silver bismuth selenide. Mineral. Mag. 1979, 43, 131-133. [CrossRef]

36. Johan, Z.; Picot, P.; Pierrot, R.; Kvaček, M. Krut'aite, $\mathrm{CuSe}_{2}$, new mineral of the pyrite group. Bull. Soc. Franç. Minéral. Cristallogr. 1972, 95, 475-481. (In French).

37. Johan, Z.; Kvaček, M.; Picot, P. Petrovicite, $\mathrm{Cu}_{3} \mathrm{HgPbBiSe}_{5}$, new Miner. Bull. Soc. Franç. Minéral. Cristallogr. 1976, 99, 310-313. (In French).

38. Johan, Z.; Picot, P.; Pierrot, R.; Kvaček, M. Fischesserite, $\mathrm{Ag}_{3} \mathrm{AuSe}_{2}$, the first selenide isotype of petzite. Bull. Soc. Franç. Minéral. Cristallogr. 1976, 94, 381-384. (In French).

39. Johan, Z.; Kvaček, M. Hakite, new mineral of the tetrahedrite group. Bull. Soc. Franç. Minéral. Cristallogr. 1971, 94, 45-48. (In French).

40. Johan, Z.; Picot, P.; Pierrot, R.; Kvaček, M. Permingeatite $\mathrm{Cu}_{3} \mathrm{SbSe}_{4}$, new mineral of the luzonite group. Bull. Soc. Franç. Minéral. Cristallogr. 1971, 94, 162-165. (In French).

41. Paar, W.H.; Topa, D.; Makovicky, E.; Culetto, F.J. Milotaite, PdSbSe, a new palladium mineral species from Předbořice, Czech Republic. Can. Mineral. 2005, 43, 689-694. [CrossRef]

42. Bindi, L.; Förster, H.J.; Grundmann, G.; Keutsch, F.N.; Stanley, C.J. Petř́čekite, CuSe 2 , a new member of the marcasite group from the Předbořice Deposit, Central Bohemia Region, Czech Republic. Minerals 2016, 6, 33. [CrossRef]

43. Dymkov, Y.M.; Loseva, T.I.; Zav'yalov, E.N.; Ryzhov, B.I.; Bochek, L.I. Mgriite, $(\mathrm{Cu}, \mathrm{Fe})_{3} \mathrm{AsSe}$, a new Miner. Zap. Vsesojuz. Mineral. Obshch. 1982, 111, 215-219. (In Russian).

44. Förster, H.J.; Cooper, M.A.; Roberts, A.C.; Stanley, C.J.; Criddle, A.J.; Hawthorne, F.C.; Laflamme, J.H.G.; Tischendorf, G. Schlemaite, $(\mathrm{Cu}, \square)_{6}(\mathrm{~Pb}, \mathrm{Bi}) \mathrm{Se}_{4}$, a new mineral species from Niederschlema-Alberoda, Erzgebirge, Germany: Description and crystal structure. Can. Mineral. 2003, 41, 1433-1444. [CrossRef]

45. Sejkora, J.; Makovicky, E.; Topa, D.; Putz, H.; Zagler, G.; Plášil, J. Litochlebite, $\mathrm{Ag}_{2} \mathrm{PbBi}_{4} \mathrm{Se}_{8}$, a new selenide mineral species from Zálesí, Czech Republic: Description and crystal structure. Can. Mineral. 2011, 49, 639-650. [CrossRef]

46. Škácha, P.; Sejkora, J.; Plášil, J. Př́ibramite, $\mathrm{CuSbSe}_{2}$, the Se-analogue of chalcostibite, a new mineral from Přibram, Czech Republic. Eur. J. Mineral. 2017. [CrossRef]

47. Škácha, P.; Sejkora, J.; Plášil, J. Bytízite, $\mathrm{Cu}_{3} \mathrm{SbSe}_{3}$, the Sb-Se analogue of witichenite, a new mineral from Př́bram, Czech Republic. Mineral. Mag. 2017, in press.

48. Růžička, J. Minerals of the Uranium Deposit Přibram; Vyd. Komitét Symp. Horn. Příbram ve Vědě a Technice: Pribram, Czech Republic, 1986; Volume 1-244. (In Czech)

49. Litochleb, J.; Sejkora, J.; Šrein, V. Selenide minerals from the Bytíz deposit (Příbram uranium-base-metal ore district). Bull. Mineral.-Petrol. Odd. Nár. Muz. 2004, 12, 113-123. (In Czech)

50. Škácha, P.; Sejkora, J. The occurrence of arsenolamprite at the Příbram uranium-polymetallic district (Czech Republic). Bull. Mineral.-Petrol. Odd. Nár. Muz. 2007, 14-15, 131-133. (In Czech)

51. Škácha, P.; Sejkora, J.; Litochleb, J.; Hofman, P. The occurrence of cuprostibite in the Přibram uranium-base metals ore district (the shaft 16, Příbram-Háje), Czech Republic. Bull. Mineral.-Petrol. Odd. Nár. Muz. 2009, 17, 73-78. (In Czech)

52. Škácha, P.; Buixaderas, E.; Plášil, J.; Sejkora, J.; Goliáš, V.; Vlček, V. Permingeatite, $\mathrm{Cu}_{3} \mathrm{SbSe}_{4}$, from Příbram (Czech Republic): Description and Raman spectroscopy investigations of the luzonite-subgroup of minerals. Can Mineral. 2014, 52, 501-511. [CrossRef]

53. Škácha, P.; Plášil, J.; Sejkora, J.; Goliáš, V. Suphur-rich antimonselite, $\mathrm{Sb}_{2}(\mathrm{Se}, \mathrm{S})_{3}$ in the Se bearing mineral association from the uranium and base metal ore district Př́bram, Czech Republic. J. Geosci. 2015, 60, $23-29$. [CrossRef]

54. Škácha, P.; Sejkora, J.; Palatinus, L.; Makovicky, E.; Plášil, J.; Macek, I.; Goliáš, V. Hakite from Př́ibram, Czech Republic: Compositional variability, crystal structure and the role in the Se-mineralization. Mineral. Mag. 2016, 80, 1115-1128. [CrossRef]

55. Sejkora, J.; Škácha, P.; Laufek, F.; Plášil, J. Brodtkorbite from Příbram, Czech Republic: Crystal structure and description. Eur. J. Mineral. 2017. [CrossRef] 
56. Škácha, P. Role of the Selenium in the Late Hydrothermal Phase of the Př́bram Uranium Region. Ph.D. Thesis, Faculty of Science, Charles University, Prague, Czech Republic, 2015.; pp. 1-235.

57. Ettler, V.; Sejkora, J.; Drahota, P.; Litochleb, J.; Pauliš, P.; Zeman, J.; Novák, M.; Pašava, J. Příbram and Kutná Hora mining districts-From historical mining to recent environmental impact. IMA 2010, Budapest, Acta Mineral.-Petrol. Field Guide Ser. 2010, 7, 1-23.

58. Litochleb, J.; Černý, P.; Litochlebová, E.; Sejkora, J.; Šreinová, B. The deposits and occurrences of mineral raw materials in the Střední Brdy Mts. and the Brdy piedmont area (Central Bohemia). Bull. Mineral.-Petrol. Odd. Nár. Muz. 2003, 12, 57-86. (In Czech)

59. Komínek, J. Geology of the Wide Surroundings and of the Deposit, Part I and II. Final Report on the Uranium District Přibram; MS DIAMO: Příbram, Czech Republic, 1995; p. 418.

60. Anderson, E.B. Isotopic-Geochronological Investigation of the Uranium Mineralization of Czechoslovakia; MS DIAMO: Příbram, Czech Republic, 1987.

61. Škácha, P.; Goliáš, V.; Sejkora, J.; Plášil, J.; Strnad, L.; Škoda, R.; Ježek, J. Hydrothermal uranium-base metal mineralization of the Jánská vein, Březové Hory, Př́bram, Czech Republic: Lead isotopes and chemical dating of uraninite. J. Geosci. 2009, 54, 1-13. [CrossRef]

62. Žák, K.; Dobeš, P. Stable isotopes and fluid inclusions in hydrothermal deposits: The Př́bram ore region. Rozpr. ČSAV, řada mat. a př́r. věd, 1991, 1-109.

63. Pouchou, J.L.; Pichoir, F. "PAP" ( $\phi \rho Z)$ procedure for improved quantitative microanalysis. In Microbeam Analysis; Armstrong, J.T., Ed.; San Francisco Press: San Francisco, CA, USA, 1985; pp. 104-106.

64. Ondruš, P. ZDS—Software for Analysis of X-ray Powder Diffraction Patterns; Version 6.01; User's Guide; ZDS System: Prague, Czech Republic, 1993; pp. 1-120.

65. Yvon, K.; Jeitschko, W.; Parthé, E. Lazy Pulverix, a computer program for calculation X-ray and neutron diffraction powder patterns. J. Appl. Crystallogr. 1977, 10, 73-74. [CrossRef]

66. Burnham, C.W. Lattice Constant Refinement; Carnegie Institute Washington Yearbook: Washington, DC, USA, 1962; Volume 61, pp. 132-135.

67. Sejkora, J.; Černý, P.; Černý, P. The occurrence of rare selenate, munakataite, at mine dump of the Lill mine, Přibram (Czech Republic). Bull. Mineral.-Petrol. Odd. Nár. Muz. 2010, 18, 87-90. (In Czech)

68. Rigaku. CrysAlis CCD and CrysAlis RED; Oxford Diffraction Ltd.: Yarnton, Oxfordshire, UK, 2016.

69. Sejkora, J.; Litochleb, J. Se-rich stibnite from the burning coal mine dump of the Kateřina mine, Radvanice near Trutnov, Czech Republic. Bull. Mineral.-Petrol. Odd. Nár. Muz. 2005, 13, 204-207. (In Czech)

70. Lundegaard, L.F.; Miletich, R.; Balic-Zunic, T.; Makovicky, E. Equation of state and crystal structure of $\mathrm{Sb}_{2} \mathrm{~S}_{3}$ between 0 and 10 GPa. Phys. Chem. Miner. 2003, 30, 463-468.

71. Kyono, A.; Kimata, M.; Matsuhisa, M.; Miyashita, Y.; Okamoto, K. Low-temperature crystal structures of stibnite implying orbital overlap of Sb 5s2 inert pair electrons. Phys. Chem. Miner. 2002, 29, 254-260. [CrossRef]

72. Liu, J.; Liu, J.; Li, J.; Xie, H.; Wang, J.; Deng, J.; Feng, C.; Qi, F.; Zhang, N. Experimental synthesis of the stibnite-antimonselite solid solution series. Int. Geol. Rev. 2008, 50, 163-176. [CrossRef]

73. Min, M.; Zhai, J.; Wang, X.; Shen, B.; Wen, G.; Fan, T. Refinement of the crystal structure for a new mineral-Antimonselite. Chin. Sci. Bull. 2008, 43, 413-416. [CrossRef]

74. Chen, L.; Zhang, Q.; Li, D.; Wang, G. Antimonselite, a new Miner. Acta Miner Sin. 1993, 13, 7-11. (In Chinese)

75. Liu, J.; Liu, J.; Liu, C.; Lu, W.; Liu, S.; Su, W. Mineralogy of the Stibnite-Antimonselite Series. Int. Geol. Rev. 1999, 41, 1042-1050.

76. Harris, D.C.; Cabri, L.J.; Kaiman, S. Athabascaite: A new copper selenide mineral from Martin Lake, Saskatchewan. Can. Mineral. 1970, 10, 207-215.

77. Johan, Z.; Picot, P.; Ruhlmann, F. Paragenetic evolution of uranium mineralization from Chaméane (Puy-de-Dôme), France: Chaméanite, geffroyite and giraudite, three new selenides of $\mathrm{Cu}, \mathrm{Fe}, \mathrm{Ag}$ and As. Tscherm. Min. Petr. Mitt. 1982, 29, 151-167. (In French). [CrossRef]

78. Grundmann, G.; Lehrberger, G.; Schnorrer-Köhler, G. The El Dragón mine, Potosí, Bolivia. Mineral. Rec. 1990, 21, 133-146.

79. Paar, W.H.; Topa, D.; Roberts, A.C.; Criddle, A.J.; Amann, G.; Sureda, R.J. The new mineral species brodtkorbite, $\mathrm{Cu}_{2} \mathrm{HgSe}_{2}$, and the associated selenide assemblage from Tuminico, Sierra de Cacho, La Rioja, Argentina. Can. Mineral. 2002, 40, 225-237. [CrossRef] 
80. Zhao, Y.; Zhang, Y.; Bi, C. Geology of gold-bearing skarn deposits in the middle and lower Yangtze River Valley and adjacent regions. Ore Geol. Rev. 1999, 14, 227-249. [CrossRef]

81. Heyding, R.D.; Murray, R.M. The crystal structures of $\mathrm{Cu}_{1.8} \mathrm{Se}_{,} \mathrm{Cu}_{3} \mathrm{Se}_{2}, \alpha$-and $\gamma \mathrm{CuSe}, \mathrm{CuSe}_{2}$, and CuSe $\mathrm{II}_{\text {. }}$ Can. J. Chem. 1976, 54, 841-848. [CrossRef]

82. Harris, D.C.; Cabri, L.J.; Murray, E.J. An occurrence of a sulphur-bearing berzelianite. Can. Mineral. 1970, 10, 737-740.

83. Makovicky, E.; Johan, Z.; Karup-Møller, S. New data on bukovite, thalcusite, chalcothallite and rohaite. Neues Jahrb. Mineral. Abh. 1980, 138, 122-146.

84. Bur'yanova, E.Z.; Kovalev, G.A.; Komkov, A.I. The new mineral cadmoselite. Zap. Vsesojuz. Miner. Obshch. $1957,86,626-628$.

85. Vavřín, I. New findings of selenides in Bohemian Massif. Bull. Mineral.-Petrol. Odd. Nár. Muz. 1994, 2, 82-89. (In Czech)

86. Scharmová, M. New findings of selenides and tellurides on the uranium deposits Zadní Chodov and Vítkov II (western Bohemia). Bull. Mineral.-Petrol. Odd. Nár. Muz. 1998, 6, 212-216. (In Czech)

87. Yashunsky, Y.V.; Ryabeva, E.G.; Abramov, M.V.; Rasulova, S.D. Dzharkenite $\mathrm{FeSe}_{2}-\mathrm{New}$ Miner. Zap. Vses. Miner. Obsh. 1995, 124, 1, 85-90. (In Russian).

88. Yakovleva, V.A.; Belogub, E.V.; Novoselov, K.A. Supergene iron sulpho-selenides from the Zapadno-Ozernoe copper-zinc massive sulphide deposit, South Urals, Russia: A new solid-solution series between pyrite $\mathrm{FeS}_{2}$ and dzharkenite FeSe 2 . Mineral. Mag. 2003, 67, 2, 355-361. [CrossRef]

89. Jolyon, R. Available online:. Available online: https://www.mindat.org/min-6907.html (accessed on 9 February 2017).

90. Kvaček, M.; Šuráň, J.; Ambrož, F. Eskebornite-New mineral for ČSSR. Čas. Miner. Geol. 1965, $10,441$. (In Czech)

91. Kvaček, M. Contribution to geochemistry of selenide mineralization in Českomoravská vrchovina-ČSSR. Sbor. 1. Geoch. Konf. Ostrav. 1965, 393-402. (In Czech)

92. Johan, Z. Crystal symmetry of eskebornite, CuFeSe 2 . Neues Jahrb. Mineral. Monatsh. 1988, 337-343.

93. Frueh, A.J.; Czamanske, G.K.; Knight, C. The crystallography of eucairite, CuAgSe, Zeit. Kristallogr. 1957, 108, 389-396. [CrossRef]

94. Pfitzner, A. Crystal structure of tricopper tetraselenoantimonate (V), $\mathrm{Cu}_{3} \mathrm{SbSe}_{4}$. Z. Kristallogr. 1994, $209,685$. [CrossRef]

95. Chen, L.; Li, D.; Wang, G.; Zhang, Q. A study of two unnamed selenide minerals. Acta Miner. Sinica 1995, 15, 418-421. (In Chinese).

96. Berger, R.A. Crookesite and sabatierite in a new light. A crystallographer's comment. Zeit. Kristallogr. 1987, 181, 241-249. [CrossRef]

97. Moëlo, Y.; Makovicky, E.; Mozgova, N.N.; Jambor, J.J.; Cook, N.; Pring, A.; Paar, W.; Nickel, E.H.; Graeser, S.; Karup-Møller, S.; et al. Sulphosalts systematics: A review. Report of the sulphosalt sub-committee of the IMA Commission on Ore Mineralogy. Eur. J. Miner. 2008, 20, 7-46. [CrossRef]

98. Makovicky, E. Crystal structures of sulfides and other chalcogenides. Rev. Miner. Geochem. 2006, 61, 7-125. [CrossRef]

99. Hatert, F.; Burke, E.A.J. The IMA-CNMNC dominant-constituent rule revisited and extended. Can. Miner. 2008, 46, 717-728. [CrossRef]

100. Velebil, D.; Macek, I.; Soumar, J. A contribution to the knowledge of the chemistry of tetrahedrites from the Czech localities: Příbram, Obecnice, Zvěstov, Mníšek pod Brdy, Ratibořské Hory, Stará Vožice, Jáchymov, Kutná Hora and Stříbrná Skalice. Bull. Mineral.-Petrol. Odd. Nár. Muz. 2016, 24, 132-143. (In Czech)

101. Kharbish, S.; Libowitzky, E.; Beran, A. The effect of As-Sb substitution in the Raman spectra of tetrahedrite-tennantite and pyrargyrite-proustite solid solution. Eur. J. Miner. 2007, 19, 567-574. [CrossRef]

102. Nakamoto, K. Infrared and Raman Spectra of Inorganic and Coordination Compounds; John Wiley and Sons: New York, NY, USA, 1986.

103. Nováček, R. Mercury rich tetrahedrites from Slovak. Zpr. Geol. Úst. 1942, 18, 107-110. (In Czech)

104. Karanović, L.; Cvetković, L.; Poleti, D.; Balić-Žunić, T.; Makovicky, E. Structural and optical properties of schwazite from Dragodol (Serbia). Neues Jahrb. Mineral. Monatsh. 2003, 11, 503-520. [CrossRef]

105. Arlt, T.; Diamond, L.W. Composition of tetrahedrite-tennantite and "schwazite" in the Schwaz silver mines, North Tyrol, Austria. Miner. Mag. 1998, 62, 801-820. [CrossRef] 
106. Foit, F.F.; Ulbricht, M.E. Compositional variation in mercurian tetrahedrite-tennantite from the epithermal deposits of the Steens and Pueblo Mountains, Harney County, Oregon. Can. Mineral. 2001, 39, 819-830. [CrossRef]

107. Karup-Møller, S.; Makovicky, E. Exploratory studies of the solubility of minor elements in tetrahedrite. Part II. Selenium and tellurium as anions in Zn-Fe tetrahedrites. Neues Jahrb. Mineral. Monatsh. 1999, 7, 385-399.

108. Karup-Møller, S.; Makovicky, E. Exploratory studies of element substitutions in synthetic tetrahedrite. Part V. Mercurian tetrahedrite. Neues Jahrb. Mineral. Abh. 2003, 179, 73-83. [CrossRef]

109. Biagioni, C.; Moëlo, Y.; Orlandi, P. Lead-antimony sulfosalts from Tuscany (Italy). XV. (Tl-Ag)-bearing rouxelite from Monte Arsiccio mine: Occurrence and crystal-chemistry. Miner. Mag. 2014, 78, 651-661. [CrossRef]

110. Bindi, L.; Keutsch, F.N.; Francis, C.A.; Menchetti, S. Fettelite, $\left[\mathrm{Ag}_{6} \mathrm{As}_{2} \mathrm{~S}_{7}\right]\left[\mathrm{Ag}_{10} \mathrm{HgAs}_{2} \mathrm{~S}_{8}\right]$ from Chañarcillo, Chile: Crystal structure, pseudosymmetry, twinning, and revised chemical formula. Am. Mineral. 2009, 94, 609-615. [CrossRef]

111. Johnson, N.E.; Craig, J.R.; Rimstidt, J.D. Compositional trends in tetrahedrite. Can. Mineral. 1986, $24,385-397$.

112. Brodin, B.V. Silver-bearing hakite. Int. Geol. Rev. 1981, 23, 71-73. [CrossRef]

113. Scharmová, M.; Scharm, B. The selenium minerals on the uranium deposit Zadní Chodov. Bull. Mineral.-Petrol. Odd. Nár. Muz. 1995, 3, 43-47. (In Czech)

114. Kopecký, S.; Pauliš, P.; Škoda, R. New occurrence of selenides from the Černý Důl uranium deposit in the Giant Mountains (Czech Republic). Bull. Mineral.-Petrol. Odd. Nár. Muz. 2010, 18, 43-49. (In Czech)

115. Wallis, W. The Paragenetic and Mineralogy Research of Selenides in Harz. Unpublished Thesis. 1994.; pp. 1-195.

116. Chakrabarti, D.J.; Laughlin, D.E. The Cu-Se (copper-selenium) system. Bull. Alloy Phase Diag. 1981, 2, 305-315. [CrossRef]

117. Whitfield, H.J. The crystal structure of hcc-CuAsSe. J. Solid State Chem. 1981, 39, 209-214. [CrossRef]

118. Bindi, L.; Catelani, T.; Chelazi, L.; Bonazzi, P. Reinvestigation of the crystal structure of lautite, CuAsS. Acta Crystallogr. Sect. E 2008, 64, i22. [CrossRef] [PubMed]

119. Litochleb, J.; Šrein, V. Silver minerals of the Příbram uranium deposit. Bull. Mineral.-Petrol. Odd. Nár. Muz. 1994, 2, 76-81. (In Czech)

120. Litochleb, J.; Šrein, V.; Knížek, F.; Sejkora, J. Mineralogy characteristic of bournonite occurrences of the Bytíz base-metal (uranium deposit Příbram). Bull. Mineral.-Petrol. Odd. Nár. Muz. 1995, 3, 219-221. (In Czech)

121. Litochleb, J.; Sejkora, J.; Šrein, V. Sulphoantimonides of lead from the base-metal vein H32A from the uranium deposit Př́bram (ore knob Háje). Bull. Mineral.-Petrol. Odd. Nár. Muz. 1997, 4-5, 163-169. (In Czech)

122. Dymkov, J.M. Selenides of uraninite-carbonate veins. In Paragenezis Mineralov Uranonosnych Žil; Izd. Nedra: Moscow, Russia, 1985; pp. 153-162. (In Russian)

123. Kvaček, M. Mineralogical-geochemical characteristic of selenide mineralization in the uranium deposit in Bohemian Massif. In Sbor. Celoštát. Miner. Semin. Mineralógia Uránových a s Nimi Súvisiacích Nerastných Surovin; Čingov: Spišská Nová Ves, Slovakia, 1987; pp. 89-95. (In Czech)

124. Simon, G.; Essene, E.J. Phase relations among selenides, sulfides, tellurides, and oxides. I. Thermodynamic properties and calculated equilibria. Econ. Geol. 1996, 91, 1183-1208. [CrossRef]

125. Simon, G.; Kessler, S.E.; Essene, E.J. Phase relations among selenides, sulfides, tellurides, and oxides. II. Application to selenide-bearing ore deposits. Econ. Geol. 1997, 92, 468-484. [CrossRef]

126. Škácha, P.; Sejkora, J.; Knížek, F.; Slepička, V.; Litochleb, J.; Jebavá, I. Occurrences of unique monometallic Ag mineralization at the H14F3 vein between the 7th and 9th level of the shaft No. 21 Háje, the Příbram uranium-base metal ore district, Czech Republic. Bull. Mineral.-Petrol. Odd. Nár. Muz. 2012, 20, 230-254. (In Czech)

127. Schønwandt, H.K. Interpretation of ore microstructures from a selenous Cu-mineralization in South Greenland. Neues Jahrb. Mineral. Abh. 1983, 146, 302-332.

(C) 2017 by the authors. Licensee MDPI, Basel, Switzerland. This article is an open access article distributed under the terms and conditions of the Creative Commons Attribution (CC BY) license (http://creativecommons.org/licenses/by/4.0/). 